\title{
Läsordning i tidigvikingatida runristningar
}

\author{
Hanna Åkerström (Uppsala University)
}

\begin{abstract}
The primary aim of this essay is to clarify the visual aspects of reading order in the early Viking Age Scandinavian runic material. The investigation in part identifies the visual principles of reading which occur in the inscriptions and in part uses these principles to support new reading orders in three inscriptions: Bo Boije4 Skee, U ANF1937;163 Björkö and DR NOR1988;5 Malt. The reading order which is examined is the one offered by the text itself, for which reason the intention of the carver and the behaviour of the actual reader is ignored. The theoretical framework of the study is based on social semiotics and a multimodal approach to text, i.e. meaning is expressed not only by language but also via tools such as image and layout. The analysis model of Kress and van Leeuwen (2006) of the grammar of visual design is specifically employed as the point of departure. The result establishes a number of visual semiotic resources. These resources express concepts such as salience, creation of associations or demarcation, which can be connected in diverse ways to functions of reading order such as start of reading or the reading pathway. Some resources seem to express none of these three concepts and can therefore be assumed to be directly linked to reading order via convention. Bo Boije4, U ANF1937;163 and DR NOR1988;5 offer several visual possibilities of reading order which are considered in turn. New reading orders have been proposed for all of these cases.
\end{abstract}

Keywords: runic inscriptions, early Viking Age, reading order, social semiotics, multimodality, Bo Boije4 Skee, U ANF1937;163 Björkö, DR NOR1988;5 Malt

$\mathrm{R}$ unristningar har traditionellt studerats med fokus på språket; skrivtecknen har lästs och runföljderna har tolkats. Däremot har den del i tolkningsprocessen som handlar om att ta ställning till en visuell kommunikation fått mindre utrymme. Föreliggande uppsats fokuserar därför på en

\footnotetext{
Åkerström, Hanna. "Läsordning i tidigvikingatida runristningar."

English: "Reading order in early Viking Age runic inscriptions."

Futhark: International fournal of Runic Studies 9-10 (2018-2019): 39-134.

DOI: $10.33063 /$ diva-401044
} 
aspekt av sådan kommunikation: visuella ledtrådar om läsordning. För att tyda en inskrift måste man bestämma i vilken ordning de olika raderna ska läsas, och centralt är då att bedöma vilka visuella resurser som är relevanta för att bestämma denna ordning. Min ambition är att visa på läsordningens visuella aspekter med utgångspunkt i det tidigvikingatida runmaterialet. Samtidigt vill jag inleda en mer principiell diskussion om hur läsordning kan studeras, samt föreslå en konkret modell för hur läsordningsprinciper som tar utgångspunkt i befintliga belägg i runmaterialet kan undersökas och slutligen visa hur dessa läsordningsprinciper kan tillämpas i analyser av enskilda ristningar. Hittills har det i stor utsträckning varit upp till den enskilda forskaren att avgöra på vilka grunder en läsordning ska bestämmas och det varierar hur stort intresse som visats frågan. Särskilt i ristningar med komplicerade radupplägg kan det skifta i vilken utsträckning forskare överhuvudtaget tar hänsyn till de ledtrådar som ristningens visualitet ger. Med sina tre ristade sidor är Gurstenstenen (Sm 144) ett exempel på detta. Enligt Otto von Friesen (1914, 2-5) ska ordningen mellan dessa tre delar av ristningen bestämmas med utgångspunkt $i$ vilken sida ristaren sett som mest fördelaktig att rista på. Däremot bortser han från hur inskriftssidornas rader förhåller sig till varandra visuellt. Två sidor rymmer nämligen rader vilka ligger kant i kant, medan den tredje sidans rad inte angränsar till någon av dessa rader. Inskriftssidorna med visuellt angränsande rader läser dock von Friesen inte efter varandra, utan den tredje sidans rad läses mellan dem. Även Ragnar Kinander (i SRI, 4: 293-295) bortser från inskriftsradernas visuella relation; han läser de tre sidornas rader i omvänd ordning jämfört med von Friesen. Kinander använder dock ett enstaka visuellt kriterium; sidan som rymmer flest runtecken och rader bör inleda menar han. Inskriftens fortsättning avgörs dock med hjälp av innehållet, då han anser att sidan där ristarformeln finns bör avsluta inskriften. De olika läsordningarna resulterar i skilda tolkningar. Den tredje sidans rad, som är visuellt skild från de övriga, innehåller enligt von Friesen och Kinander en apposition (VifríðaR/ VifrøðaR [s]un[aR] 'Vifrids sons'). Appositionen tolkas som en bestämning till ett mansnamn som nämnts i den föregående raden. Eftersom von Friesen och Kinander gjort olika bedömningar av vilken den föregående raden är ser de heller inte appositionen som en bestämning till samma person.

Det tycks alltså finnas ett behov av att diskutera vilka faktorer som ska tas hänsyn till då läsordning bestäms. Eftersom ristningarnas visualitet i detta sammanhang är central har jag valt att fokusera på de visuella resursernas betydelse för vilken läsordning som erbjuds i texten. Detta betyder inte att inskrifternas språkliga dimension har mindre relevans för att avgöra var läsningen startar respektive fortsätter. Denna aspekt är 
bara inte i fokus här. Uppsatsens huvudsakliga bidrag till forskningen om runmaterialet är slutsatser kring vilka visuella läsordningskonventioner som det tidigvikingatida runmaterialet ger uttryck för samt en fördjupad diskussion av tre ristningar (Bo Boije4 Skee, DR NOR1988;5 Malt och U ANF1937;163 Björkö) där jag med utgångspunkt i de principer för läsordning jag urskilt argumenterar för andra ordningar än de allmänt vedertagna. Syftet med den sistnämnda delen är att visa hur man på enbart visuella grunder kan resonera kring svårtolkade inskrifters läsordning. Resultaten från dessa resonemang kan förhoppningsvis vara en tillgång $i$ arbetet mot en språklig tolkning.

\section{Syfte}

Studiens första syfte är:

- Att identifiera (eventuella) gemensamma principer för textens visuella erbjudande om läsordning(ar) i det nordiska runmaterialet från tidig vikingatid.

För att kunna analysera runtexterna med avseende på visuella läsordningsprinciper använder jag ett teoretiskt ramverk hämtat från socialsemiotiken samt utarbetar en metod grundad på framförallt Gunther Kress och Theo van Leeuwens (2006) analysmodell för bildens grammatik. Jag hämtar också inspiration från Marco Bianchis (2010) socialsemiotiska studie, som är den viktigaste tidigare undersökningen med en egentlig teoretisk diskussion av hur just runinskrifters läsordning kan förstås och undersökas. Avsikten är att säga något generellt om läsordningskonventioner i det tidigvikingatida runmaterialet. Jag har däremot inte som ambition att utveckla en teori om läsordningsprinciper som sträcker sig utanför mitt undersökningsmaterial.

För att kunna identifiera visuella principer som visar på en viss läsordning måste denna ordning först fastställas på andra grunder än det visuella. Endast inskrifter vars läsordning kan bestämmas på språklig basis utgör därför underlag för analysen som svarar mot studiens första syfte. På tre ristningar vars läsordningar inte kan bestämmas på språklig grund vill jag istället pröva att tillämpa de på så sätt fastställda läsordningsprinciperna. Studiens andra syfte är därmed:

- att använda de identifierade läsordningsprinciperna för att föreslå visuellt erbjuden läsordning för tre tidigvikingatida runtexter vars läsordning inte är språkligt given. 
Medan studiens första syfte är mer teoretiskt och metodiskt inriktat har studiens andra syfte i första hand ett empiriskt fokus; argument för tidigare föreslagna läsordningar utvärderas utifrån de läsordningsprinciper jag formulerat samtidigt som jag föreslår nya möjligheter.

\section{Läsordning - tidigare forskning}

Att skaffa sig en överblick över vad som skrivits om läsordning i runmaterialet är svårt. Få studier intresserar sig för fenomenet i sig. Otaliga undersökningar finns emellertid av enskilda inskrifter där läsordning ibland diskuteras mer eller mindre utförligt i samband med studiens huvudsyfte: den språkliga tolkningen. De drag som tas upp som relevanta utgår ofta från den aktuella ristningens specifika karaktär och kan därför skilja sig mycket åt. Sällan diskuteras explicit från vilket perspektiv studien görs, men ofta anar man att det är avsändarens, det vill säga ristarens, läsordning som undersöks. Ibland görs utredningar av konventioner för inskriftsupplägg i ett större material som stöd för en viss argumentation, som Ottar Grønviks (1981, 131-137) sammanställning av bustrofedontyper i samband med en diskussion av Tunestenens (N KJ72) läsordning. ${ }^{1}$ Även om sådana längre utredningar är sällsynta stöds de framförda argumenten ofta av någon typ av hänvisning till hur materialet ser ut i stort. Ibland förs emellertid resonemanget i första hand utifrån förhållandet i inskriften ifråga, som till exempel Evert Salbergers (1980, 17-29) diskussion av läsordningen på Oklundahällen (Ög N288) som utgår från skiljetecknens placering i just denna inskrift. Studier av enskilda ristningar kan i detta sammanhang visserligen fungera som inspiration för vilka faktorer som kan vara potentiellt relevanta för att bestämma läsordning. Undersökningar av denna typ säger dock i allmänhet mindre om läsordningsprinciper generellt eller teoretiska och metodiska överväganden då sådana principer ska undersökas.

Några studier finns som tar ett grepp om ett större material och diskuterar detta på en mer principiell nivå. Jag har försökt fånga upp några huvudlinjer bland dessa undersökningar. Ett antal består av kategoriseringar av olika typer av upplägg av rader/slingor i ett visst material. Det varierar dock i hur hög grad radupplägg diskuteras i förhållande till läsordning specifikt. Exempelvis går Kinander (i SRI, 4: 10-13) inte in särskilt på läsordning i sin genomgång av radupplägg i det småländska materialet, medan Erik Moltke (i $D R$, Text, sp. 820-827) i sin indelning av de danska

\footnotetext{
${ }^{1}$ Att rader i en komposition löper bustrofedon innebär att de (i ett vertikalt radupplägg) i varannan rad löper nedifrån och upp respektive uppifrån och ned (t.ex. $\uparrow \downarrow \uparrow \downarrow)$.
} 
runristningarna även anger läsordning. Ett annat exempel är Claiborne Thompsons (1975) kategorisering av radupplägg i det uppländska materialet. Det varierar också i hur hög grad kategoriseringen mynnar ut i ett resonemang kring textkonventioner. Exempelvis presenterar Moltke bara sin kategorisering med tillhörande belägg, medan till exempel Grønvik låter sin ovan nämnda uppdelning av bustrofedonupplägg mynna ut i slutsatser om textnormer. I indelningar av denna typ finns emellertid ingen egentlig problematisering av fenomenet läsordning, vilket heller inte är studiernas avsikt, eller hur detta kan undersökas. Istället är utgångspunkten ofta en allmänt vedertagen läsordning för ett antal inskrifter utifrån vilka kategoriseringen av raduppläggen görs.

Det finns emellertid ett fåtal studier där målet mer uttalat är att säga något nytt om läsordning. Detta gäller exempelvis Elmer $\mathrm{H}$. Antonsens (2002, 119-148) studie av det urnordiska materialet. De principiella slutsatser han drar utifrån en genomgång av inskrifternas läsordning handlar i första hand om att tillbakavisa Moltkes (1981, 84-88) påstående att i det urnordiska materialet är en bestämd läsordning mellan ristningens olika enheter mindre viktig jämfört med att all information inkluderas och att ristningsytan fylls. Antonsen $(2002,148)$ menar att det inte finns belägg för Moltkes påstående; materialet visar att raduppläggen inte är slumpmässiga. Ingen diskussion förs egentligen om utifrån vilket perspektiv läsordningen undersöks, men det framgår att Antonsen (t.ex. s. 133, 139) intresserar sig för ristarens ordning. Faktorer han lyfter fram som relevanta för att bestämma läsordning är både grafiska drag och syntaktiska relationer (s. 133 f.).

Även i Bianchis (2010) studie av det uppländska och södermanländska senvikingatida materialet är bland annat läsordningsprinciper ett uttalat syfte. Undersökningen bygger dessutom på en explicit uttryckt teoretisk utgångspunkt och metoddiskussion. Bianchi tar avstamp i en socialsemiotisk teori, inom vilken fler verktyg än språket ses som potentiellt meningsskapande. Han lyfter särskilt fram de betydelser som uttrycks visuellt, och genom att diskutera den visuella kompositionens möjlighet att realisera betydelse knuten till läsordning har hans studie varit en inspiration för föreliggande uppsats. Bianchi identifierar gemensamma mönster i materialet och detta fungerar som utgångspunkt för ett resonemang kring vilka konventioner som kan ha funnits för hur läsordning signalerades visuellt. Exempelvis kan han visa (s. 111) att lässtart ofta återfinns i den vänstra delen av rundjuret, något som Bianchi $(2008,29) \mathrm{i}$ en mindre studie också konstaterar gäller för materialet från Kronobergs län. Vidare inkluderas läsaren som en självklar del vid sidan om ristaren i den interaktion 
som runristningarna är en del av och diskussionen utgår ofta från hur läsaren erbjuds att skapa mening i en runtext. Även Per Holmberg (2016) intresserar sig för läsordning utifrån ett socialsemiotiskt perspektiv. Med utgångspunkt i Bianchis resultat formulerar han (s. 70 f.) den labyrintiska principen. Den innebär att läsaren vet att lässtart troligen finns nere till vänster men hur läsvägen fortlöper kan hen inte känna till på förhand, utan fortsättningen hittar läsaren i den närmaste slingan eller raden. Holmberg använder denna princip för att ompröva läsordningen på Rökstenen.

Exempel finns också på studier där runristningarnas visuella aspekter visserligen är i fokus men där de betydelser som de antas uttrycka inte i första hand knyts till läsordning. Bland annat resonerar Judith Jesch (1998, 468-470) kring möjligheten att olika ord kan framhävas som viktigare än andra, exempelvis genom placering på stenen. Också Gunhild Øeby Nielsen $(2001,167)$ diskuterar något liknande då hon beskriver radupplägg i det danska materialet. Även Bianchi (2010, 112-114) intresserar sig, i sin undersökning av hur inskriftsformler avskiljs från varandra inte bara syntaktiskt utan också visuellt, för hur visualitet samspelar med det språkliga innehållet. Nämnas ska också Anders Andréns (2000) studie av ett eventuellt samband mellan slingupplägg och personrelationer i inskriften, även om hans slutsatser inte kan accepteras (se t.ex. Bianchi 2010, 38 f.).

\section{Material och metod}

\section{Avgränsning av materialet}

Undersökningsmaterialet utgörs av det nordiska tidigvikingatida runmaterialet, och inkluderar både ristningar i sten och på lösföremål. Perioden sträcker sig från 700-talets början och slutar ungefär i mitten av 900-talet. Startpunkten motiveras av att det då sker en övergång från den äldre urnordiska runraden till den yngre vikingatida, vilket innebär en stor förändring av runristartraditionen. Det skifte som motiverar att sätta stopp runt 900-talets mitt handlar om att kristna minnesinskrifter då börjar produceras och snart är den texttyp som dominerar (sten)materialet.

Materialurvalet är i flera fall komplicerat och jag skiljer därför på inskrifter som med all sannolikhet hör till perioden ifråga och sådana för vilka det finns en större tveksamhet. De sistnämnda förs till en "osäker grupp" och markeras med ett "?" före signumet. För en mer utförlig motivering av avgränsningen, beskrivning av urvalskriterierna samt en inskriftsförteckning se Åkerström 2019. Sammanlagt räknar jag 132 signum till det tidigvikingatida materialet, men min definition av komposition (all ristning på 
ett objekt) innebär att några av signumen (N 282-N 284 Trå 1-3 respektive N A210-N A211 Slemmedal) räknas till samma komposition samtidigt som ett signum rymmer fler än en komposition. Enligt Magnus Källström (2013,108, not 5) ryms på så sätt fragment från fem olika runstenar under signumet U 9 Björkö. ${ }^{2}$ De 132 signumen motsvarar därmed 133 kompositioner och dessa utgör studiens undersökningsmaterial.

Då inget annat är angivet är translitterering och transkribering för de svenska och norska inskrifterna hämtade från Samnordisk runtextdatabas, dock kompletterad med vokallängd. Translittering, transkribering och översättning är för de danska inskrifterna hämtade från databasen Danske Runeindskrifter då inget annat anges. Emellertid translittereras åsrunan genomgående enligt den praxis som gäller i Samnordisk runtextdatabas (d.v.s. med o i vikingatida inskrifter). Skiljetecken återges i translittereringen enligt bruket i databasen Danske Runeindskrifter (d.v.s. genomgående :). Dubbelläsning av runor återges inte i tablå 2-3 där delar av undersökningsmaterialet presenteras (se vidare nedan).

\section{Indelning av materialet i två grupper}

\section{Presentation av grupp 1 och 2}

För att kunna genomföra analysen delas materialet (133 kompositioner) in i två grupper. Till grupp 1 förs de ristningar där principer för textens visuella erbjudande om läsordning kan studeras (62 stycken; tablå 2-4). Närmare bestämt ingår de kompositioner vars läsordning helt eller delvis går att bestämma på språklig grund samt inskrifter med endast en inskriftsrad. I likhet med Bianchi (2010) utgår jag alltså från språkligt grundande kriterier för att bestämma läsordning och undersöker sedan vilka visuella resurser som tycks visa på denna språkligt givna ordning (vilket svarar mot studiens första syfte). De språkliga kriterierna har utarbetats efter en genomgång av undersökningsmaterialet. Tillvägagångssättet förutsätter att språket är den överordnande resursen, det vill säga den läsordning som urskiljs utgår från vad som är språkligt rimligt, utan hänsyn till om de visuella resurserna verkligen tycks bekräfta denna ordning eller ej. Av de 62 kompositionerna i grupp 1 består 35 stycken bara av en inskriftsrad (tablå 4). Här är läsordningen alltså given. De enradiga kompositionerna kan inte ligga till grund för att bestämma vilka visuella ledtrådar som signalerar läsordning mellan olika visuella element (som rader eller partier av rader på olika sidor

${ }^{2}$ En av dessa stenar är enligt Källström möjligen en slipsten och kunde därmed eventuellt ha uteslutits här. 
av det ristade objektet). För detta kan bara de återstående 27 ristningarna med mer komplexa radupplägg användas (tablå 2 och 3). Till sist bör påpekas att det endast är ordningen mellan de olika typerna av visuella element som bestäms utan stöd av ristningens visualitet. Elementen i sig har urskilts på bland annat visuella grunder (se vidare nedan).

Grupp 2 består av ristningar där principer för textens visuella erbjudande om läsordning inte kan undersökas, det vill säga sådana fall där läsordningen (helt eller delvis) inte kan bestämmas på språklig grund (85 stycken; tablå 3, 5 och 6). För tre av dessa ristningar (Bo Boije4 Skee, DR NOR1988;5 Malt och U ANF1937;163 Björkö) prövas de läsordningsprinciper som framkommit ur analysen av grupp 1 (vilket svarar mot studiens andra syfte). Det är att märka att i 14 fall är olika delar av en och samma komposition förd till antingen grupp 1 eller 2; mellan vissa av de ingående elementen går ordningen att bestämma på språklig grund (grupp 1), medan det mellan de övriga inte går att avgöra (grupp 2). Vidare förs ristningar till grupp 2 om de är alltför skadade eller helt har gått förlorade samtidigt som de inte är tillräckligt pålitligt eller informativt återgivna genom foton eller teckningar. Detta görs eftersom analysen kräver uppgifter om ristningens visuella uppbyggnad. Framförallt rör det sig om ett antal enradiga kompositioner där det är osäkert om fler rader en gång har funnits. Samtliga skadade ristningar är inte uteslutna eftersom några trots skador eller knapphändiga teckningar kan ge information om vissa aspekter av deras visuella läsordningsprinciper.

Jag utgår inte från att indelningen i grupp 1 och 2 speglar en verklig artskillnad mellan runristningarna utan kategoriseringen grundar sig i hur de kan användas i analysen, men man kan givetvis spekulera i om en eventuell skillnad kan bestå just i att den språkligt grundade läsordningen är friare i grupp 2 än i grupp 1.

En snedfördelning finns i grupp 1 vad gäller materialtyp och geografisk spridning. Av de 27 flerradiga kompositionerna återfinns bara tre på lösföremål (totalt finns i materialet 79 ristningar på sten och 54 på lösföremål). Vidare är 20 från danskt (av totalt 56) och 7 från svenskt (av totalt 57) område. Inga norska eller utomnordiska ristningar (totalt 16 respektive 4) ingår i grupp 1. Geografiska och materialmässiga skillnader försöker jag uppmärksamma. Däremot väljer jag att inte kommentera kronologiska skillnader eftersom endast delar av materialet kan föras till första respektive andra halvan av den undersökta perioden. Särskilt ristningar på sten är svårt att datera närmare.

Undantagsvis anges i tablå 2-6 vilken specifik tolkning jag utgått från för den språkliga analysen, och då i första hand för de inskrifter som förts 
till grupp 1. För övriga inskrifter för vilka flera föreslagna tolkningar finns gäller i allmänhet att dessa olika alternativ inte påverkar möjligheten att på språklig grund bestämma en läsordning, antingen på grund av att jag bedömt samtliga föreslagna tolkningar som alltför osäkra för att använda som utgångspunkt eller att tolkningsförslagen rör detaljer som inte påverkar bedömningen av den språkligt grundade läsordningen.

\section{Språkligt grundade kriterier för gruppindelningen}

För att ordningen mellan de visuella element som ingår i en komposition ska bedömas som språkligt given måste de språkliga sambanden mellan elementen uppfylla vissa kriterier. Kriterierna är av skiftande slag - framförallt handlar det om lexikogrammatiska ${ }^{3}$ samband i satsen men också om semantiska relationer - och har utarbetats efter en genomgång av materialet. Inledningsvis presenteras ett antal kriterier i punktform och därefter förs en längre diskussion om de tre sista punkterna (något som emellertid inte innebär att dessa väger tyngre i analysen).

Bedömningen av huruvida ordningen mellan visuella element $i$ en komposition är språkligt given eller inte utgår från följande kriterier:

- den ordning mellan kompositionens visuella element som ger det mest troliga syntaktiska sammanhanget bedöms som språkligt given. ${ }^{4} \mathrm{Om}$ exempelvis ett visuellt element avslutas inuti en fras och endast ett annat element kan utgöra andra delen av frasen bedöms denna ordning som språkligt given. Kriteriet kan vidare innebära att en ordning där satsled är en integrerad del i satsen betraktas som språkligt given till förmån för alternativa ordningar där så inte är fallet, även om de sistnämnda inte behöver vara syntaktiskt inkorrekta. Exempelvis räknar jag inte med att första raden, ki-mutr $G \bar{e}[R]$ mundr(?), på DR 110 Virring ska förstås som ristarsignatur av typen ensamstående namn i nominativ (jfr t.ex. DR 105 Laurbjerg) utan snarare som del i resarformeln, som inleds ki-mutr : ....n : kạrpi $G \bar{e}[R]$ mundr(?) ... [su]n gærði. Kriteriet innebär också att om de visuella elementen enkelt går att ordna så att regeln om verbet på andra plats i huvudsatsen följs bedöms denna ordning som språk-

\footnotetext{
${ }^{3}$ Språklig mening realiseras genom enstaka ord eller ord kombinerade med varandra. Lexikogrammatik avser sättet detta görs på (Holmberg och Karlsson 2006, 20).

${ }^{4}$ Kriteriet har inte formulerats i termer av syntaktiskt korrekt i motsats till syntaktiskt inkorrekt eftersom det är svårt att veta säkert vad som uppfattades som syntaktiskt korrekt under tidig vikingatid.
} 
ligt given. ${ }^{5}$ Slutligen bedömer jag visuella element som en osannolik lässtart för inskriften om de innehåller satser vilka förutsätter ett underförstått subjekt;

- om en viss ordning är en förutsättning för att det semantiska sammanhanget ska vara rimligt bedömer jag denna ordning som språkligt given. Exempelvis räknar jag med att Rökstenens (Ög 136) pat sagum annart '[d]et säger jag som det andra' föregår pat sagum tvalfta '[d] et säger jag som det tolfte' (Wessén 1958, 25), men också att visuella element som inleds av ok eller liknande är osannolika lässtarter för inskrifter. Det är dock inte alltid lätt att avgöra när något är semantiskt rimligt eftersom inskrifternas innehåll ofta är svårförståeligt och vi vet alltför lite om den kontext de kommit till i;

- om ett visuellt element avslutas mitt i ett ord och det endast finns ett annat element som kan utgöra den andra halvan av ordet ifråga bedöms denna ordning som språkligt given;

- den ordning där flest visuella element kan ingå bedöms som språkligt given. Om exempelvis både ordningen rad 1-2 och 1-3 är språkligt möjlig i en treradig komposition men endast ordningen 1-2-3, inte 1-3-2, fungerar språkligt, då räknar jag med att ordningen 1-2-3 är språkligt given;

- om ett element innehåller en släktskapsbeteckning räknar jag med att detta bör följa efter det element där namnet på personen ifråga finns. Det kan dock vara osäkert om släktskapsbeteckningen verkligen syftar tillbaka på ett redan nämnt namn eller om den avser en icke namngiven person. Exempelvis syftar kona 'kvinna; hustru' (Peterson 1994, 27) på DR 209 Glavendrup troligen tillbaka på den tidigare omnämnda Ragnhildr, men det är samtidigt möjligt att personen som omtalas som kona aldrig nämns vid namn;

\footnotetext{
${ }^{5}$ Kriteriet är i linje med antaganden om hur regeln om verbet på andra plats i huvudsatsen har utvecklats (se t.ex. Sangfelt 2019, 50 m. litt.). Samtidigt finns indikationer på variation i ordföljden under den period jag undersöker. Exempelvis har argument framförts för att rester av en äldre SOV-ordföljd (subjekt - objekt - verb) finns kvar ännu en bit in på vikingatiden (jfr Peterson 1992, 102 f., om Bo Peterson1992 Hoga). Vidare finns bland det tidigvikingatida materialet möjligen exempel på att ett finit verb inleder hela inskriften på DR 333 Örja och DR 221 Vordingborg (men beläggen är osäkra på grund av ristningarnas skador), samt på ?DR 356 Sölvesborgs kyrka (fler exempel finns på finit verb initialt $\mathrm{i}$ en sats som inte inleder inskriften, jfr Wessén 1965, 215 f.). Nämnas ska också formuleringen på DR 209 Glavendrup, At rǣ̇dda(?) sā verði es stæin pannsi ælti(?) [...] 'Til en 'ræte' vorde den, som ailti denne sten [...]' (databasen Danske Runeindskrifter), med verbet på tredje plats. De enstaka undantag som finns för regeln om verbet på andra plats är emellertid inte tillräckliga för att ändra kriteriet.
} 
- om en språklig tolkning av en viss inskrift är alltför osäker används den inte för att bestämma en läsordning på språklig grund;

- visuella element innehållande förbannelseformler läses sist i inskriften;

- visuella element som bildar fraser av typen X:s sten (eller annat ord för minnesmärke) placeras i en ordning som ger ett framförställt genitivattribut;

- det visuella element som innehåller den syntaktiska enhet där runristningens avsändare (resare eller ristare) presenteras räknar jag med inleder inskrifter av minneskaraktär. Undantag som formeltypen aft $X$ där mottagaren (den avlidna) inleder finns dock. Enligt Rune Palm (1992, 138, 143 f.) förekommer formeltypen aft X under förvikingatid och under vikingatid, men är sällsynt. Om flera avsändare finns representerade tar jag inte ställning till ordningen mellan dem.

De tre sista kriterierna skiljer sig från de övriga då de inte utgår från lexikogrammatiska regler eller semantiska sammanhang utan från vissa utmärkande drag som texttypen tidigvikingatida steninskrifter antas uppvisa. Dragen återfinns alltså i dessa inskrifter, men för att undvika cirkelresonemang bör kriterierna etableras utifrån ett annat material, i första hand det som föregår det tidigvikingatida, det vill säga urnordiska inskrifter och övergångsinskrifter. Är ett drag också belagt under sen vikingatid styrker detta antagandet om att det bör ha funnits under tidig vikingatid. I det följande redovisas på vilka grunder jag upprättat de tre sista kriterierna.

Att förbannelseformler riktade mot den som förstör monumentet troligen finns i inskriftens avslutning hittar man stöd för i två övergångsinskrifter. De horisontala raderna på DR 360 Björketorp har vid ett tillfälle ett radbyte mitt i ett ord, vilket visar att här läses raderna nedifrån och upp. Om samma ordningsföljd antas gälla för samtliga rader avslutar en förbannelseformel inskriftens ena sida. På DR 357 Stentoften avslutar troligtvis förbannelseformeln hela inskriften (Åkerström Manus). En skillnad mellan inskrifter med förbannelseformler i mitt material och de två övergångsinskrifterna är dock att de sistnämnda inte har en uttrycklig minneskaraktär.

Att fraser av typen X:s sten (eller annat ord för minnesmärke) har ett framförställt genitivattribut (annars är efterställt attribut det typiska i nominalfraser från perioden ifråga, jfr Wessén 1965, 103) kan styrkas i det urnordiska materialet: N KJ78 Bø, N KJ81 Stenstad och möjligen på N KJ79 Tomstad, samt på N KJ60 Vetteland som består av mer än frasen $X: s$ 
sten (Antonsen 2002, 291 f.). Det sistnämnda gäller även N Viking2011;28 Hogganvik. Det ska också nämnas att bland de tidigvikingatida runristningarna finns formuleringen representerad i tre inskrifter (Bo KJ80 Rävsal, DR 17 Starup och DR 70 Hammel 1) med bara en inskriftsrad (ordningen mellan frasleden kan alltså inte ifrågasättas).

Att avsändaren (ristaren eller resaren) oftast presenteras inledningsvis i inskrifter av minneskaraktär är som bekant belagt i det senvikingatida materialet. De urnordiska inskrifterna uppvisar däremot en något brokigare bild. Frågan kompliceras av att det många gånger är svårt att avgöra namnbärarens roll i de ofta kortfattade urnordiska inskrifterna samt att läsordningens tvetydighet ofta möjliggör flera alternativ. Frågan om avsändarens plats i det urnordiska materialet skulle egentligen kräva en mer ingående studie än vad som finns utrymme för här. Jag utgår (med några egna tillägg) i huvudsak från Antonsen (2002) och i någon mån Palm (1992). Båda har emellertid andra syften med sina studier än att diskutera ordningen mellan mottagare och avsändare. Antonsen (2002, 207-235) gör en indelning av materialet i olika inskriftstyper (med utgångspunkt i semantiska och syntaktiska skillnader men också utifrån typ av ristningsobjekt). Tre av dessa typer kan kopplas till en minnespraktik. Den första utgörs av steninskrifter med enstaka namn i nominativ eller i genitiv (och då ofta följt av ett ord för ett monument eller en grav). Antonsen anser att namnet troligtvis ska förstås som betecknande den person som ska ihågkommas (alltså mottagaren). Den andra inskriftstypen utgörs av uttryckliga minnesinskrifter. Antonsen tar upp Bo KJ73 Rö, N KJ71 By, N KJ72 Tune och N KJ75 Kjølevik. Enligt hans läsordning inleder mottagaren inskriften på Kjølevikstenen, medan avsändaren inleder Rö-, By- och Tunestenens inskrifter genom olika varianter av en $e k X$-formel (på Rö- och Tunestenen finns dock flera avsändare). På Tunestenen (med två ristade sidor) är det emellertid möjligt med en läsordning där den avlidna istället inleder (även andra alternativ är tänkbara, se Antonsen 2002, 126-134). Även på Rö- och Kjølevikstenen är en annan läsordning möjlig. Jag vill nämna ytterligare tre inskrifter i samband med inskriftstypen uttryckliga minnesinskrifter: DR 359 Istaby (en övergångsinskrift), N KJ74 Reistad och N Viking2011;28 Hogganvik. Vad gäller Reistadstenen tycks den avlidna inleda inskriften, medan läsordningen är mer tvetydig på de övriga två. Vidare överväger Palm $(1992,142)$ att räkna U 877 Möjbro till minnesinskrifterna, vilket ger ytterligare ett exempel på att den avlidna inleder inskriften. I samband med inskriftstypen uttryckliga minnesinskrifter nämner Antonsen (2002, 223 f.) också stenristningar med fler än ett namn i nominativ (N KJ58 Årstad och Sö 24 Berga). Förutom att det är svårt att vara säker på vem som är 
avsändare respektive mottagare är läsordningen här mycket osäker. Den tredje av Antonsens (s. 224-230) inskriftstyper består av steninskrifter utan verb. ${ }^{6}$ Bland denna typ är det vanligast att avsändaren inleder med en ek X-formel (N KJ55 Valsfjord, N KJ56 Veblungsnes, N KJ65 Nordhuglo och N KJ69 Rosseland). Troligen inleder avsändaren även på N KJ53 Kårstad men inskriften har en möjlig alternativ läsordning. Jag vill också nämna ytterligare några inskrifter som inte uttryckligen anknyter till en minnespraktik men där avsändaren (med mer eller mindre säkerhet) presenterar sig inledningsvis (någon mottagare är däremot inte nämnd): N KJ63 Einang, N KJ64 Barmen, N KJ68 Vatn, Vr 1 Järsberg, Sö Fv2011;307 Strängnäs och Òg KJ59 Ällerstad. Även Palm (1992, 133-174) diskuterar olika formeltyper i minnesinskrifter från urnordisk tid och övergångsperioden ("förvikingatid" hos Palm) samt från vikingatid, men fokuserar snarare på förekomsten av, inte ordningen mellan formlerna. Han urskiljer dock en formeltyp aft $X$ där mottagaren inleder inskriften. Han konstaterar (s. 138-143) att i det förvikingatida materialet framkommer inget klart mönster vad gäller typ av minnesformel som ingår i inskriften. Genomgången ovan ger även den en skiftande bild, även om avsändaren oftare tycks presenteras inledningsvis jämfört med mottagaren. Att ändå använda ordningen dem emellan som ett kriterium motiveras framförallt av att det bland de senvikingatida minnesinskrifterna i regel är avsändaren som inleder. Bianchi (2010, 70 f., 94) visar att de senvikingatida minnesinskrifterna från Uppland och Södermanland nästan alltid inleds med en minnesformel där avsändaren, i allmänhet resaren och i några fall ristaren, presenteras först.

Möjligen är det problematiskt att på detta sätt utgå från utmärkande drag i det tidigvikingatida materialet och sedan leta sig bakåt i tiden för att hitta liknande fenomen; en kontinuitet i skrifttraditionen förutsätts därmed mellan de båda perioderna. Hade utgångspunkten istället varit karaktären hos texttyper under urnordisk tid och under övergångsperioden som sedan jämfördes med det tidigvikingatida materialet hade själva analysen fătt visa på ett sådant eventuellt samband. Det finns dock stöd för att anta en koppling mellan tidsepokerna. Förutom att användningen av skriftsystemet förutsätter kontinuitet, trots de förändringar det genomgår, finns framförallt beröringspunkter mellan övergångsinskrifter och det tidigvikingatida materialet. Exempelvis finns minnesinskrifter med formuleringen aft $X$ representerade i båda grupperna samt förbannelseformler riktade mot den

${ }^{6}$ Palm (1992, 139 f.) menar emellertid att en av de inskrifter (N KJ60 Vetteland) Antonsen (2002, 229 f.) räknar till typen inskrifter utan verb, skulle kunna ha innehållit en fullständig minnesformel.

Futhark 9-10 (2018-2019) 
som förstör monumentet. Inskrifter som Ög 136 Rök och Ög 43 Ingelstad visar dessutom att det fanns en fortsatt tradering av urnordiska runtecken, även om dessa inte längre var en del av den vikingatida futharken.

\section{Teoretisk ram}

\section{Textens erbjudande om läsordning}

Läsordning kan förstås på olika sätt. Då läsordning diskuteras inom tidigare runologisk forskning definieras sällan undersökningsobjektet uttryckligen, men i de flesta fall framgår det av framställningen att det i första hand är avsändarens (d.v.s. ristarens) intentioner man fokuserat på, inte exempelvis vilken väg en mottagare tar genom inskriftens rader. Ett exempel är Moltkes presentation (se ovan) av olika inskriftsupplägg där han diskuterar vad ristaren gjort eller inte gjort. Reception av runtext är något som överhuvudtaget fått mindre uppmärksamhet inom runologisk forskning (vilket påpekats av Bianchi 2010, 34; exempel på undersökningar av ett historiskt material med fokus på reception är dock Bäckvall 2013 och Petrulevich 2016). Men frågan är också vilken läsordning som är möjlig att undersöka. Både en faktisk ristares respektive en faktisk läsares läsordning är i själva verket svår att komma åt för oss idag. Det är exempelvis inte självklart hur man ska avgöra vilka läsordningsrelaterade resurser som en ristare har använt medvetet och vilka som kommit i bruk av en slump (jfr dock Jan Meyers 1992 diskussion av i vilken utsträckning runristare planerade ristningens upplägg i förväg), eller om ristaren konstruerade ett radupplägg som tillät flera alternativa läsvägar. $\AA$ andra sidan, är det heller inte givet hur man ska bedöma vilka resurser som en samtida faktisk läsare tolkade som relevanta för att bestämma textens läsordning.

Jag väljer därför att varken undersöka den faktiska ristarens eller den faktiska läsarens läsordning, utan föreliggande studie behandlar den ordning texten själv erbjuder visuellt. Med text avses här själva ristningen, såväl det språkliga som det visuella, inklusive det ristade objektet. I ett material som det tidigvikingatida, där vi enbart har tillgång till runtexterna men saknar interaktionen kring dem är detta en möjlig väg att gå. Textens visuella erbjudanden handlar alltså bara om den läsordning som konstrueras i själva texten och kan diskuteras utan att man behöver ta ställning till en ristares eventuella intentioner eller huruvida en samtida faktisk läsare uppfattade läsordningen just så. En undersökning av textens visuella erbjudande innebär vidare en studie av textkonventioner. Jag menar att de visuella drag som erbjuder läsordning i en text (mer eller 
mindre) måste vara en del av de konventioner som styr hur text organiserades i den tidigvikingatida skriftkulturen. Konventionerna bör alltså vara synliga i texten och kan därmed studeras genom den. Att fokus ligger på textkonventioner är också en konsekvens av karaktären hos materialet; eftersom många inskrifter är mycket korta består analysen i första hand av att identifiera relevanta visuella drag för den sammanlagda textmassan, inte den enskilda ristningen. De visuella principer för läsordning som identifieras går på så sätt utöver den enskilda texten och handlar snarast om just gemensamma konventioner i skriftkulturen ifråga. För enkelhetens skull talar jag fortsättningsvis om textens erbjudande men avser med detta endast textens visuella erbjudande.

Textsynen som beskrivs här utgår från Umberto Eco. Eco (1981, 7-11) intresserar sig mer specifikt för den läsare (modelläsare) som finns inbäddad i själva texten. Han menar att de val textens avsändare gör styrs av vilken typ av läsare som texten antas möta, och därmed kan också denna förväntade läsares egenskaper spåras i texten. Exempelvis kan texten berätta om vilka kompetenser i form av språk- och genreförståelse modelläsaren besitter, eller mer specifik information som ålder (visuella medel kan t.ex. signalera texttypen barnbok). Modelläsaren är därmed inte en faktisk läsare, men texten inbjuder den faktiska läsaren att inta modelläsarens position (vilket hen kan acceptera, motarbeta eller kanske inte vara kapabel till). Jag använder inte modelläsare som analytiskt begrepp men betraktar alltså de tidigvikingatida runtexterna på ett liknande sätt; utifrån förväntningar på hur läsordning bestäms visuellt har texterna utformats på ett visst sätt. Inbäddat i texten finns därmed information om detta förväntade beteende, eller med andra ord: I texten finns ett erbjudande om att bete sig på ett visst sätt i förhållande till läsordning (som en faktisk läsare kan anta eller förkasta). Eco utgår från skönlitteratur, men angreppsättet har även använts på sakprosa (t.ex. Björkvall 2003, 2004, Tønnesson 2003, 2004 och Nord 2008). Dessa studier rör mer komplext skriftbruk än det jag intresserar mig för. Anders Björkvall (2003) undersöker exempelvis hur modelläsaren konstrueras i reklamannonser och Andreas Nord (2008) hur trädgårdsböckers utformning möjliggör vissa läsarbeteenden. Jag angriper istället mer grundläggande frågor om ordningen mellan de ingående visuella elementen.

\section{Tre typer av visuella element}

För att studera textens visuella erbjudande om läsordning måste de enheter definieras mellan vilka ordningen ska bestämmas. Bianchi (2010, 
59-61) arbetar med termen visuell skriftenhet för att undersöka visuellt avgränsade delar i en text. En liknande indelning är användbar här. Dock passar inte Bianchis kriterier för vad som utgör en visuell skriftenhet det tidigvikingatida materialet eftersom enheterna här i de flesta fall består av rader, inte av slingor och djurornamentik. Dessutom vill jag inte utesluta att eventuella bilder eller ornamentik också kan ha haft en plats i läsordningen (en undersökning av detta överstiger emellertid ramen för denna uppsats). Därför använder jag istället beteckningen visuella element, efter Anna-Malin Karlsson $(2002,42)$ som till skillnad från Bianchi även arbetar med avgränsade ytor utan skrift. Även Björkvall $(2009,24)$ använder textelement med samma innebörd.

Jag räknar med att tre olika typer av visuella element är relevanta för att bestämma läsordning: (inskrifts)rad, (inskrifts)parti respektive (inskrifts)komposition. Elementen avser själva ristningen (både dess visuella och språkliga aspekter även om det förstnämnda aktualiseras oftare) inte objektet, men hänsyn tas till hur elementen är placerade på objektet. ${ }^{7}$ Rad är en följd av ristade runor som (mer eller mindre) oavbrutet löper ungefär i en och samma riktning, ofta omgiven av gemensamma ramlinjer. Det tredimensionella objektet består av olika sidor och ett parti avser de ristade rader som befinner sig på samma sida (jfr t.ex. Gustavson och Selinge 1988, 54). Komposition utgörs av all ristning på ett objekt. Elementen fungerar alltså hierarkiskt på så sätt att kompositionen kan rymma en eller flera partier och inskriftspartiet kan i sin tur rymma en eller flera rader. Då läsordningen bestäms i en komposition med flera partier prövas först ordningen mellan rader inom ett parti, inte mellan rader som tillhör olika partier. Därefter prövas ordningen mellan hela inskriftspartier. Jag skiljer (i likhet med Holmberg 2016, 70 f.) på frågan om var kompositionens början finns och frågan om hur den ska fortsätta läsas. Med lässtartavses alltså startpunkten för de olika visuella elementen, medan läsväg syftar på vägen från denna punkt. Läsordning använder jag som en sammanfattande term för dessa två. Samtliga element prövas med avseende på lässtart, det vill säga radens, partiets och slutligen hela kompositionens lässtart. Läsväg undersöks däremot bara mellan rader inom ett inskriftsparti samt mellan partier inom en komposition, men inte mellan kompositioner. Bland lösföremålen finns dock ristning på olika objekt som eventuellt ska läsas i samband med varandra, till exempel två bleck (U NOR2002;26 Björkö bleck 1 och U NOR2002;28 Björkö bleck 2)

${ }^{7}$ Ristning syftar på alla spår av ristning på ett objekt, medan inskrift avser de ristade skrivtecknen. 
som är fästade vid varandra med en koppartråd, samt två delar av ett smycke där N A210 och N A211 Slemmestad finns på en del och N A212 på den andra (Liestøl 1982, 44-47).

Eftersom inskriftsparti räknas som ett självständigt visuellt element behandlas varje parti i flerparti-ristningar separat i den visuella analysen av grupp 1. Vart och ett av dessa partier analyseras därmed tillsammans med de ristningar som bara består av ett parti. Tillvägagångssättet är möjligen problematiskt eftersom nivåerna parti och komposition blandas (i kompositioner med bara ett parti motsvarar dessa nivåer varandra). Det är exempelvis troligt att i kompositioner med flera partier kan dessa vara visuellt självständiga från varandra i olika hög grad beroende på om partiets rader exempelvis är lagda kant i kant (t.ex. DR 143 Gunderup 1, se fig. 1) eller är placerade på motsatta sidor (t.ex. DR 41 Jelling 1, se fig. 9), medan inskriftspartier i enparti-kompositioner per definition inte står i relation till andra visuella element. Vidare visar resurserna närliggande startpunkt för parti samt avstånd till startpunkt för parti (se nedan) att partiers rader i flerparti-kompositioner kan förhållas till varandra på olika sätt. Att ändå likställa samtliga kompositioners partier i analysen motiveras framförallt av materialbristen. Av de totalt 27 flerradiga ristningarna i grupp 1 består 13 av fler än ett parti och ska dessa behandlas separat blir underlaget för analysen ännu mindre. Kompositionsnivån i flerparti-ristningar undersöks dock separat.

\section{Urskiljande av de visuella elementen}

Valet att använda just de tre visuella elementen rad, parti och komposition får konsekvenser för undersökningens resultat och urskiljandet av dem ska därför kort motiveras. Utarbetandet av kriterier för elementen är i första hand gjort på visuella grunder efter en genomgång av de radupplägg som finns representerade i hela undersökningsmaterialet. För parti ligger även språkliga kriterier till grund.

De tidigvikingatida runristningarnas visuella uppbyggnad består i princip uteslutande av raka med varandra sammanhängande runföljder vilka har samma läsriktning: rader. Några exempel finns på att runföljder inom samma ramlinjer har olika läsriktning (exempelvis på DR 4 Haddeby 4) och dessa har bedömts som två olika rader. Några undantag från de rakt placerade runföljderna finns; slingor har till exempel använts på DR 34 Horne och ?G 266 Stenkyrka kyrka. Det är heller inte alltid självklart huruvida en runföljd som till viss del ändrar riktning ska räknas som en eller två rader (t.ex. N 140 Valby). Raderna kan vara en eller flera och är nästan alltid placerade vertikalt. Möjliga undantag utgörs av ristningar 
på lösföremål och på häll; det är svårt att veta huruvida dessa runföljder betraktades vertikalt eller horisontellt. Av de resta stenarna ska raderna på U 4 Björkö eventuellt ses horisontellt (A. Setons avbildning i SRI, 6: $7 \mathrm{av}$ ristningen då stenen fortfarande är intakt visar horisontella rader). Samma sak gäller några av de gotländska bildstenarna (t.ex. ?G 252 Lokrume kyrka och G 310 Hangvars kyrka), men på grund av skador är det osäkert om där dessutom funnits vertikala rader. Exempel finns på kompositioner med både vertikala och horisontalt lagda rader (t.ex. DR NOR1988;5 Malt och Ög 136 Rök).

Vidare består vissa kompositioner av ristning som skiljs åt genom att vara fördelad på olika sidor av objektet: partier. För att en eller flera rader ska utgöra olika inskriftspartier krävs att sidorna de är ristade på befinner sig i vinkel mot varandra. Hur skarp denna vinkel måste vara är inte självklart och det finns gränsfall, exempelvis räknar jag parti B och C på DR 230 Tryggevælde som två, medan ?G 280 Pilgårds med sin rundade form bedöms ha endast ett parti. Majoriteten av materialet består emellertid av kompositioner med bara ett parti. Det finns ett par fall (DR 2 Haddeby 2 och DR 4) där rader sträcker sig från en inskriftssida till en annan. De hör på så sätt egentligen till två olika partier, men i analysen bedöms de som enbart del i det parti där radstarten finns. I båda fallen befinner sig också större delen av raden ifråga i detta parti.

Slutligen kan själva kompositionen i sig, det vill säga all ristning på ett objekt, ses som en enda enhet avskild visuellt från de övriga i materialet. Det ristade objektet är i de allra flesta fall oproblematiskt att identifiera. Man kan dock fråga sig var gränserna går för till exempel ristade berghällar.

Elementet inskriftsparti urskiljs även utifrån språkliga kriterier. Kompositioner i grupp 1 vilka rymmer fler än ett parti (identifierade enbart på visuella grunder) som i sin tur rymmer fler än en rad prövas med avseende på om den språkligt givna läsordningen (utifrån ovan beskrivna kriterier) visar att alla rader inom ett inskriftsparti läses klart innan nästa påbörjas. Om läsordningen skulle visa sig hoppa fram och tillbaka mellan rader inom olika partier skulle inskriftspartier inte kunna behandlas som sammanhållna element mellan vilka läsordning upprättas. Så är emellertid aldrig fallet. I följande fall läses hela partiet klart innan nästa påbörjas: DR 2 (parti A), ${ }^{8}$ DR 4 (A), DR 41 Jelling 1 (A), DR 143

\footnotetext{
${ }^{8}$ Strikt talat börjar den inledande raden på DR 2 i parti A och sträcker sig över på en angränsande sida. Eftersom den rad som läses efter den inledande också startar i parti A räknar jag detta som ett exempel på att partiet läses klart innan nästa påbörjas (i tablå 2 räknas hela den inledande raden till parti A).
} 
Gunderup 1 (A), DR 189 Avnslev (A), DR 209 Glavendrup (C) och Sm 144 Gursten (B). ${ }^{9}$

Huruvida rader ska läsas klart prövas inte utifrån språkliga kriterier. Anledningen är dels att elementet $i$ hög grad är etablerat i tidigare forskning som enheter mellan vilka läsordning bestäms, dels att en prövning av huruvida samtliga rader inom varje komposition i grupp 1 ska läsas klart innan nästa påbörjas skulle innebära ett alltför stort arbete. Nämnas ska dock att det på DR 4 finns ett exempel på att runföljder inom samma ramlinjer inte ska läsas efter varandra. Runföljderna ifråga har emellertid olika läsriktning (en runföljd löper nedifrån och upp, den andra uppifrån och ned) och klassas därför som två olika inskriftsrader.

\section{Socialsemiotik}

Undersökningens teoretiska ramverk utgår från socialsemiotiken med särskilt fokus på textens multimodala aspekter. Inom socialsemiotiken ses språk som ett bland många andra redskap med potential att uttrycka betydelse (Holmberg och Karlsson 2006, 29). Det multimodala perspektivet innebär att fokus även läggs på meningsskapande system vid sidan om språket. Det kan till exempel röra sig om hur bild, färg och layout används (Svensson och Karlsson 2012, 17). Jag använder begreppet semiotiska resurser för att tala om det visuella som motsvarar språkets lexikogrammatiska resurser, det vill säga de sätt på vilka en text kan komponeras visuellt. Semiotiska resurser definieras av van Leeuwen $(2005,3)$ som "the actions and artefacts we use to communicate". Semiotiska resurser uttrycker alltså betydelse. Van Leeuwen (s. 3-6) framhåller att en resurs aldrig har en fast betydelse utan snarare en betydelsepotential. Dock kan inte vilka betydelser som helst uttryckas; resurser fungerar inom en social gemenskap och det är inom denna gemenskap som regleringen sker av vad de semiotiska resurserna kan användas till. När det kommer till runristningar uttrycks alltså betydelser inte bara språkligt utan också genom andra resurser som till exempel val av radupplägg, ristningsmaterial och plats. Dessa resurser uppfattar en betraktare förmodligen innan det språkliga innehållet ens är dechiffrerat, och ibland kanske oavhängigt huruvida innehållet ens är möjligt att avkoda (jfr Bianchi 2010, 165-222 om

\footnotetext{
${ }^{9}$ Då rader eller partier som tillhör ristningar ur grupp 1 anges syftar detta här och fortsättningsvis på uppställningen i tablå 2 och 3 . Inskrifterna redovisas där enligt en allmänt vedertagen läsordning och ska inte förstås som att jag alltid tar ställning för denna ordning. Själva indelningen i rader och partier följer dock mina definitioner av dessa visuella element.
}

Futhark 9-10 (2018-2019) 
icke-lexikala inskrifter). Fokus för denna studie ligger på sådana visuella resurser som i den tidigvikingatida skriftkulturen har givits potential att uttrycka betydelser knutna till funktioner som har med läsordning att göra (som lässtart och läsväg). I analysen aktualiseras alltså meningsskapande inom dessa tre skikt: semiotisk resurs, betydelse och funktion.

\section{Semiotiska resurser, betydelse och funktion}

För att undersöka samspelet mellan semiotisk resurs, betydelse och funktion använder jag Kress och van Leeuwens (2006) analysmodell av bildens grammatik. De har som ambition att med utgångspunkt i den språkbeskrivning som används inom den systemisk-funktionella grammatiken (den centrala språkteorin inom socialsemiotiken) upprätta en fullständig analysmodell för bildens grammatik. Försöket att analysera bild utifrån en modell som i första hand är anpassad för att beskriva språk har dock kritiserats (se t.ex. Machin 2007, 159-188), och till exempel van Leeuwen (2005) har istället ett något annat fokus (Kress och van Leeuwens Reading images gavs ut första gången 1996). De delar av modellen som rör hur text kan organiseras visuellt har emellertid visat sig användbara för mina syften eftersom de erbjuder verktyg för att undersöka vilka typer av betydelser som de olika resurserna kan tänkas realisera samt hur dessa betydelser kan kopplas till funktioner som lässtart och läsväg. De betydelsesystem som Kress och van Leeuwen $(2006,177)$ formulerat och som visat sig relevanta är framskjutenhet, avgränsning och sambandskapande (svenska termer från Björkvall 2009, 84-110). Kress och van Leeuwen (2006, 177) räknar också med att visuella element kan ges olika betydelse beroende på vilken del av bildytan de befinner sig på, det vill säga placeringen på ytan ger elementen olika informationsvärde. De menar (s. 179-181) exempelvis att $\mathrm{i}$ en bild där horisontalaxeln utnyttjas är information som befinner sig till vänster given, det vill säga redan känd av mottagaren, medan informationen som presenteras till höger är ny. Att det under tidig vikingatid fanns jämförbart utvecklade konventioner vad gäller skriftytans meningsskapande har jag inte sett tecken på. Dock kan vissa delar av kompositionen kopplas till specifika läsordningsfunktioner (se vidare nedan om resursen placering av rad).

Betydelsen framskjutenhet kan alltså realiseras med hjälp av olika typer av visuella semiotiska resurser, till exempel storlek på runorna. Resurser kan också enligt Kress och van Leeuwen (2006, 201-206) uttrycka framskjutenhet i olika hög grad, vilket i icke-linjära kompositioner potentiellt kan skapa en hierarki mellan olika visuella element. Denna hierarki menar Kress och van Leeuwen är kopplad till hur viktigt elementet ifråga är, ju 
mer framskjutet desto mer värt en betraktares uppmärksamhet. Utifrån detta resonemang kan kopplingen mellan framskjutenhet och funktioner som lässtart och läsväg bestå $\mathrm{i}$ att det mest framskjutna elementet läses först, därefter det näst mest framskjutna och så vidare.

Betydelserna avgränsning respektive sambandskapande kan realiseras med hjälp av visuella semiotiska resurser som exempelvis avstånd respektive närhet mellan visuella element. Dessa presenteras då enligt Kress och van Leeuwen (2006, 203 f.) som om de är skilda från varandra respektive hör ihop. Betydelsesystemen ifråga förstår jag därmed som kopplade till läsordningsfunktioner på så sätt att de motverkar respektive främjar en viss läsväg, däremot säger de ingenting om lässtart.

Konkret urskiljs resurser genom att jag först tittar på varje enskild komposition separat, det vill säga en bedömning görs av vilka visuella egenheter som just här verkar indikera den språkligt givna ordningen. Därefter tittar jag på tendenser i hela materialet, det vill säga en granskning görs av vilka typer av visuella drag som tycks återkomma på flera objekt. Även om varje komposition i princip studeras för sig finns exempel på att visuella uttryck kopplade till själva radupplägget framträder först i jämförelse med andra ristningar. Exempelvis blir det påtagligt att raders slut är placerade nära andra raders början i ett helt genomfört bustrofedonupplägg först när detta upplägg jämförs med en komposition där radernas läsriktning konsekvent löper nedifrån och upp. Vad gäller visuella uttryck som runstorlek eller avstånd mellan rader studeras emellertid varje komposition för sig.

Även om en kvalitativ bedömning görs av varje komposition är som framgått ovan frekvens en viktig indikator för att tolka något som en resurs; i ett historiskt material är det svårt att på annat sätt mäta hur centrala olika visuella drag kan ha varit för att indikera läsordning. Det har också varit ett sätt att sålla bland de visuella drag som förekommer i materialet så att antalet urskilda resurser inte ska bli ohanterligt stort. Samtidigt vill jag vara öppen för att visuella drag som man inte tidigare satt i samband med läsordning kan vara relevanta. I vissa fall har därför resurser urskilts trots att endast ett eller två belägg finns på dem. Framförallt handlar det om resurser med två varianter varav en är frekvent och den andra inte är det (t.ex. har resursen runstorlek två varianter, större respektive mindre runformer, där den sistnämnda endast finns ett par exempel på). Men det förekommer också fall där ett visuellt uttryck tolkas som en resurs trots att bara ett eller ett par belägg finns, eftersom den i dessa kompositioner på ett påtagligt sätt har betydelse för ett visuellt erbjudande av läsordning.

Tre antaganden styr urskiljandet av resurser som uttrycker något av de tre betydelsesystemen. Antagandena har delvis berörts tidigare men 
ska här kort kommenteras. För det första förutsätts som ovan nämnts de språkliga resurserna vara överordnade de visuella, det vill säga att i analysen antas de visuella resurserna visa på den språkligt givna läsordningen. För det andra räknar jag med att detta görs enligt de samband mellan betydelse och funktion som förutsägs i Kress och van Leeuwens modell (framskjutenhet knyts till lässtart, sambandskapande till läsväg och avgränsning till var läsväg inte går). För det tredje räknar jag med att i större utsträckning kunna identifiera visuella uttryck som realiserar sambandskapande respektive avgränsning när dessa handlar om fysisk närhet eller avstånd, men i mindre utsträckning kunna uttala mig om vilka visuella uttryck som realiserar framskjutenhet under tidig vikingatid. En konsekvens av dessa antaganden är att den/det språkligt givna startraden/startpartiet förutsätts realisera framskjutenhet visuellt, och oavsett om det visuella uttrycket ifråga utgörs av relativt större eller mindre runor, längre eller kortare rad och så vidare, tolkas det som en resurs som uttrycker framskjutenhet. Jag öppnar alltså inte för möjligheten att den språkligt givna startraden tvärtom skulle vara mindre framskjuten än de andra raderna. Vad gäller de visuella uttryck som potentiellt erbjuder den språkligt givna läsvägen utgår jag däremot inte från att alla dessa realiserar sambandskapande respektive avgränsning, utan bara de som handlar om fysisk närhet respektive avstånd förstås som resurser. Tillvägagångssättet har både för- och nackdelar. Risken minskar att mina förutfattade meningar om materialet styr identifieringen av resurser knutna till lässtart. Samtidigt kan det hända att visuella uttryck som inte realiserade framskjutenhet under tidig vikingatid tolkas som resurser. Omvänt riskerar jag eventuellt att förbise resurser knutna till läsväg som inte handlar om fysisk närhet respektive avstånd. Kress och van Leeuwen (2006, 204) tar exempelvis upp visuellt rim (svensk term från Björkvall 2009, 105) där sambandskapande kan uttryckas genom att exempelvis färger eller former upprepas. Möjligen skulle visuellt rim kunna sägas binda samman de av Rökstenens (Ög 136) rader som rymmer samma skriftsystem, men ingen sådan resurs urskiljs här eftersom fenomenet är dåligt belagt.

Rent praktiskt har undersökningen gjorts genom en uppskattning av de visuella resurserna utifrån fotografier eller då så varit möjligt utifrån en personlig undersökning av objekten. Måttangivelser anges då så är motiverat, men oftast inte.

Avslutningsvis kan man fråga sig i vilken utsträckning Kress och van Leeuwens modell är tillämpbar på ett historiskt material som runristningarna. Kress och van Leeuwen (2006, 3 f.) har utgått från västerländskt 
material och menar inte att alla delar av modellen ska förstås som universellt tillämpbara. Exempelvis påpekar de (s. 192) att det är kulturellt betingat vilket informationsvärde som tillskrivs olika delar av en skriftyta, till exempel den till höger respektive den till vänster, men menar samtidigt att riktning i sig är en resurs som potentiellt kan användas för att uttrycka betydelse i alla kulturer. På ett liknande sätt betraktar jag de mer övergripande betydelsesystemen framskjutenhet, sambandskapande och avgränsning som allmängiltiga och räknar med att dessa betydelser kan kopplas till läsordning i det tidigvikingatida materialet så som beskrivits ovan. Hur de tre betydelsesystemen mer specifikt realiseras ses däremot som kulturspecifikt. Kress och van Leeuwen diskuterar detta vid flera tillfällen. Exempelvis påpekar de (s. 201-206) att det är kulturellt betingat vilka visuella resurser som uttrycker till exempel framskjutenhet. De nämner också att läsvägens riktning, till exempel i en cirkel, vertikalt eller horisontalt, kan ges olika betydelse i olika kulturella sammanhang. I så stor utsträckning som möjligt försöker jag därför (med ovan nämnda begränsningar) vara öppen för att visuella resurser av olika typer kan ha använts för att realisera de olika betydelsesystemen. Jag utgår heller inte från listor av de slag Kress och van Leeuwen (s. 202-204, 210) presenterar, där olika resurser som har potential att realisera framskjutenhet, sambandsskapande respektive avgränsning räknas upp, utan försöker istället låta materialet styra vilka visuella drag jag klassar som relevanta. Slutligen begränsar jag mig heller inte till att endast räkna med sådana resurser som uttrycker någon av de tre betydelserna. I materialet förekommer nämligen resurser kopplade till läsordning som inte tycks realisera något av de tre betydelsesystemen. Dessa resurser antar jag är knutna direkt till läsordning genom konvention, det vill säga genom överenskommelser inom en social gemenskap om hur text organiseras med avseende på läsordning. Detta ska dock inte tolkas som ett ställningstagande för att dessa resurser är mer välförankrade i en tidigvikingatida textnorm än de övriga; även de resurser som jag räknar med uttrycker något av de tre betydelsesystemen kan antas vara del av en konvention.

\section{Starkt respektive svagt markerat erbjudande om läsordning}

Resurser kan resultera i olika starkt markerade erbjudanden om läsordning. Graden av framskjutenhet hos olika element kan exempelvis vara kodad olika starkt, och olika visuella resurser kan i samspel med varandra realisera till exempel framskjutenhet, vilket kan bidra till att en viss läsordning erbjuds starkt i en text (Kress och van Leeuwen 2006, 204-208). På 
samma sätt kan man diskutera gradskillnader vad gäller i vilken utsträckning resurser uttrycker avgränsning respektive sambandskapande mellan olika element i en text. I det följande redogörs efter vilka principer jag graderar resurser.

Huruvida visuella resurser resulterar i ett starkt eller svagt markerat erbjudande om läsordning används i första hand som argument då jag lägger fram nya läsordningsförslag för tre runristningar ur grupp 2. Två omständigheter påverkar bedömningen. För det första tittar jag på huruvida resurserna är tydliga eller otydliga i den enskilda kompositionen. En tydlig resurs kan till exempel vara mycket större runor i en rad jämfört med andra, medan en otydlig resurs kan vara marginellt större runor. Flera otydliga resurser kan tillsammans resultera i ett starkt markerat erbjudande om läsordning, medan flera motsägelsefulla, men tydliga, resurser kan resultera i flera svagt markerade erbjudanden. För det andra utgår bedömningen från om resurserna är frekventa eller infrekventa i grupp 1. En frekvent resurs antar jag resulterar i ett starkare markerat erbjudande och tvärtom. Flera infrekventa resurser skulle tillsammans kunna ge ett starkt markerat erbjudande om läsordning, medan flera frekventa resurser som pekar i olika riktningar kan resultera i olika svagt markerade erbjudanden. Vidare kan man också tänka sig att en resurs som är infrekvent men mycket tydlig, eller omvänt mycket frekvent men otydlig, resulterar i ett starkt markerat erbjudande. Ytterligare något ska sägas om hur de resurser som består av flera varianter behandlas. Exempelvis kan runstorlek innebära att framskjutenhet uttrycks antingen genom större eller mindre runor. Bedömningen av vilken av varianterna som är aktuell i en viss komposition utgår från vad som upplevs som visuellt framskjutet just där. Om alla rader utom en innehåller runor i samma storlek uttrycks framskjutenhet i denna visuellt avvikande rad vare sig den består av jämförelsevis mindre eller större runor. Ibland går det inte att avgöra vilken av varianterna som är aktuell; en komposition kan exempelvis bestå av endast två rader eller det kan vara fråga om resurser av typen placering av rad som inte uttrycker någon av de tre betydelserna utan vars tre varianter snarare handlar om riktning (lässtart finns antingen i raden längst till vänster, höger eller i mitten). Här räknar jag med att den mest frekventa varianten resulterar i det starkast markerade erbjudandet.

Jag tar inte för givet att det finnas en automatisk koppling mellan min bedömning av vad som är ett starkt respektive svagt markerat erbjudande och i vilken utsträckning de resurser som ligger till grund för erbjudandet är förankrade i tidigvikingatida textkonventioner. Förutom 
att möjliga felkällor finns i min analysmodell måste tidigvikingatida textkonventioner inte ha varit entydiga. Infrekventa resurser måste exempelvis inte ha resulterat i svaga erbjudanden om läsordning enligt samtida textkonventioner. Vad gäller tydliga eller otydliga resurser skulle man kunna tänka sig att en resurs är otydlig just eftersom den är väl förankrad i konventionen och alltså inte behöver markeras mer än så.

En gradering i starkt respektive svagt markerade erbjudanden om läsordning låter oss förhålla olika alternativa läsordningar i en text till varandra, vilket är användbart då enskilda ristningar analyseras. Det ska dock framhållas att då jag i de tre avslutande exempelanalyserna visar att flera alternativa läsordningar erbjuds samtidigt i en text avser jag endast de visuellt erbjudna läsordningarna. För att uttala sig om huruvida det verkligen finns flera sätt att kombinera de ingående elementen i en komposition måste dessa alternativ förhållas till en språklig tolkning. Det vill säga, består elementen av sådant språkligt innehåll att de kan kombineras på olika sätt eller krävs en viss ordning för att det ska bli begripligt? Jag håller det för troligt att det $\mathrm{i}$ vissa ristningar i det tidigvikingatida materialet finns en större öppenhet för olika alternativa kombinationer av elementen utifrån språk och/eller visualitet. En undersökning av denna aspekt ryms dock inte i detta sammanhang.

\section{Resultat}

Följande avsnitt där resultatet redogörs för består av två delar. I den första presenteras resultatet från analysen av grupp 1, det vill säga den grupp runristningar vars läsordning helt eller delvis kan bestämmas på språklig grund. Analysen syftar till att fastställa (eventuella) gemensamma principer för hur runtexter från tidig vikingatid erbjuder läsordning visuellt, närmare bestämt ringa in vilka visuella semiotiska resurser som kan kopplas till läsordningsfunktioner. I det andra avsnittet visar jag hur dessa principer för visuellt erbjuden läsordning kan tillämpas på en del av det tidigvikingatida materialet, närmare bestämt på tre ristningar ur grupp 2 (Bo Boije4 Skee, U ANF1937;163 Björkö och DR NOR1988;5 Malt) vars läsordning inte är språkligt given.

\section{Principer för textens visuella erbjudanden om läsordning}

Grupp 1, som följande avsnitt utgår från, består av hela eller delar av läsordningen från totalt 62 kompositioner (se tablå 2-4). Ristningar på sten (39 stycken) respektive på lösföremål (23 stycken) hålls isär i redovisningen 
men eftersom det oftast handlar om resultat från de förstnämnda nämns materialtyp uttryckligen bara när exemplen kommer från lösföremål. Hänvisningar till en specifik rad eller parti refererar till uppställningen av allmänt vedertagna läsordningar i tablå $2-3$, och ska inte förstås som att jag alltid tar ställning för just denna ordning. Indelningen i rader och partier följer emellertid definitionerna av dessa två element. Kompositionernas visuella uppbyggnad har olika grad av komplexitet och kan därför bidra till slutsatser om visuella läsordningsprinciper i olika stor utsträckning. Minst komplicerade är radupplägget för de 35 ristningar ur grupp 1 som bara består av en rad (se tablå 4). Dessa aktualiseras endast undantagsvis i resultatredovisningen och då så är fallet påpekas att beläggen kommer från enradiga kompositioner.

Inledningsvis diskuteras lässtart, närmare bestämt redovisas de visuella resurser som på olika sätt uttrycker framskjutenhet kopplad till funktionen lässtart. Därefter behandlas läsväg; först presenteras visuella resurser som uttrycker grad av framskjutenhet, sedan de som realiserar sambandskapande och till sist de som uttrycker avgränsning. Därnäst diskuteras vad jag antar är konventionaliserade resurser knutna till lässtart och läsväg, det vill säga resurser som tycks vara kopplade till läsordning utan att uttrycka betydelser av typen framskjutenhet, sambandskapande eller avgränsning. I ett avslutande avsnitt presenteras några fallbeskrivningar med avsikt att ge en bild av hur resurser kan fungera tillsammans inom en enskild komposition.

Ristningar på häll- och lösföremål i grupp 1 får en särskild behandling i analysen. Till skillnad från ristningar på resta stenar, där det i de flesta fall är okomplicerat att avgöra vad som är upp och ned, höger och vänster, är ristningens riktning i kompositioner på häll- och lösföremål inte självklar. För att ändå kunna inkludera dessa ristningar i de delar av analysen där radernas riktning används som utgångspunkt antar jag att raderna på häll- och lösföremål, med avseende på lässtart, är arrangerade på samma sätt som i kompositioner på resta stenar, det vill säga startraden är placerad vertikalt med en läsriktning nedifrån och upp. På så sätt tillskrivs ristningar på häll- och lösföremål emellertid en visuell resurs som eventuellt aldrig har funnits där: läsriktning $i$ rad (resursen innebär just att lässtart i ett vertikalt radupplägg finns i en rad vars läsriktning löper nedifrån och upp, se vidare nedan). Tillvägagångssättet motiveras av att resursen ifråga förekommer i samtliga kompositioner på resta stenar vilket kan göra det troligt att runrader oftast betraktades på detta sätt även då ristningsobjektets plats i rummet var fri. Dock finns också problem med antagandet. Man kan exempelvis tänka sig att just 
möjligheten att betrakta raderna i olika riktningar är en visuell resurs i ristningar på lösföremål och häll. Det är dessutom en glidande skala i vilken mån ristade rader på lösföremål och häll saknar en bestämd riktning. Tre ristningar ur grupp 2 kan illustrera detta: För N 138 Oseberg 2, som är ristad på en spann, finns i större utsträckning en given riktning genom själva ristningsobjektet, medan samma sak inte kan sägas för U Fv1913;276 Björkö som finns på en brynsten. Vidare gör placeringen av hällristningen Ȯg 43 Ingelstad framför en klippavsats att raderna lättast betraktas horisontellt istället för vertikalt. Vad gäller de lösföremål (en järnring, en kam och en bit av ett kranium) och den hällristning som ingår i grupp 1 är dock radernas riktning mer fri.

\section{Lässtart: Visuella resurser som uttrycker framskjutenhet}

I flertalet fall kan jag på språklig grund bestämma i vilken rad inskrifter ska börja läsas och därmed även i vilket parti. De visuella resurser som kopplas till det element där lässtart finns är antingen sådana som uttrycker framskjutenhet, det vill säga betydelsen att framskjutna element i något avseende är viktigare än andra mindre framskjutna element och därför läses först, eller är av en typ som jag antar är knuten till lässtart genom konvention. Den förstnämnda varianten presenteras i det följande, medan den sistnämnda tas upp i ett avslutande avsnitt i samband med liknande resurser knutna till läsväg. Inledningsvis redogörs för lässtart i partier (d.v.s. startrad). Därefter diskuteras lässtart för hela kompositioner med fler än ett parti (d.v.s. startparti).

\section{Lässtart: Startrad}

Sju olika typer av visuella resurser finns som uttrycker framskjutenhet och där detta kan kopplas till lässtart i ett parti. Det handlar alltså om hur startraden markeras visuellt. Resurserna har det gemensamt att de visuellt avviker från övriga delar av kompositionen i olika avseenden (ofta genom storlek) och på så sätt realiserar framskjutenhet.

Resursen runstorlek finns i två varianter, större respektive mindre runor. Oftast uttrycks framskjutenhet genom att en av raderna (ibland bara inledningsvis, ibland senare i raden) innehåller till höjden och ofta också bredden större runor än de övriga. Större runor kan knytas till funktionen lässtart i ett parti i följande fall: DR 41 Jelling 1, DR 110 Virring (parti A; lässtart bör finnas i antingen rad 1 eller 2 som båda har större runor än de övriga raderna i partiet), DR 143 Gunderup 1 (parti A; startradens runor är inledningsvis c:a 2-4 cm större, egen mätning), DR 202 Rønninge (de två 
raderna som läses först har större runor än den sista), DR 248 Snoldelev, DR 250 Høje Tåstrup (runorna i raden där lässtart finns är ett par centimeter större än övriga, mätning i $D R$ ), DR 209 Glavendrup (parti C), DR 230 Tryggevælde (A), Ög 8 Kälvesten (A; startradens runor är inledningsvis c:a $3 \mathrm{~cm}$ större än de övriga, egen mätning), Ög 136 Rök (A). Inga klara exempel förekommer bland lösföremålen. Dock finns på ett fragment av en kam, DR MLUHM1983-84;131 Lilla Köpinge, fyra rader varav bara två är tolkade. Den rad som läses först av dessa två har större runformer än den andra, men det är alltså osäkert om denna rad utgör hela partiets lässtart.

Några få exempel finns på att startrad utmärks av relativt mindre runor. Dessa fall är också ofta mindre tydliga. Bland ristningar på sten finns exempel på mindre runor inledningsvis i startraden på DR 30 Bække 2 och på Òg N288 Oklunda (åtminstone jämfört med raderna placerade i samma riktning; se fig. 8). Även DR 143 Gunderup 1 ska nämnas (se fig. 1). I parti $B$ har den andra och enligt den språkligt givna läsordningen avslutande raden något större runor (c:a 13-15 cm, egen mätning) än den första (runhöjden är c:a 9-11 cm, medan avståndet mellan ramlinjerna är c:a 12-13,5, egen mätning). Storleksförhållandet är emellertid det omvända för de två raderna i parti $\mathrm{A}$. Eftersom de två partierna står i nära visuell förbindelse, på så sätt att raderna är lagda intill varandra längsmed en av stenens kanter, ska troligen parti B inte betraktas som en visuellt helt självständig enhet. Därför är kanske en tydligt markerad startrad i parti B på DR 143 inte heller att vänta sig.

Resursen radläng $d$ realiserar framskjutenhet genom att en rad är relativt längre alternativt kortare än de övriga. Varianten med en längre startrad består antingen av en rad som är längre än samtliga övriga rader, eller av en kantrad i ett vertikalt radupplägg som är längre än den motsatta kantraden medan radlängden däremellan kan variera. Varianten där en längre rad kan knytas till funktionen lässtart i ett parti förekommer i följande fall: DR 2 Haddeby 2 (parti A), DR 29 Bække 1, ?DR 40 Randbøl, DR 202 Rønninge, DR 248 Snoldelev (om man tittar på ramlinjens längd; runföljderna är däremot ungefär lika långa), U 4 Björkö, DR 209 Glavendrup (parti C), Sm 144 Gursten (B; men bara marginellt), Òg 136 Rök (A). Svårkategoriserade är raderna i parti A på DR 209 (se fig. 2) respektive i parti A på DR 230 Tryggevælde; kantraden där lässtart finns är i dessa fall kortare eller ungefär lika lång som den motsatta kantraden, men längre än de däremellan. Bland lösföremålen finns ett exempel på resursen ifråga, nämligen i parti B på Hs 7 Forsa kyrka. Även här kan emellertid DR MLUHM1983-84;131 Lilla Köpinge nämnas; den första av de två tolkade raderna är längre än den andra. 
Att startraden i ett parti istället är relativt kortare förekommer på DR 250 Høje Tåstrup, Ög 8 Kälvesten (parti A) och Òg N288 Oklunda. Om man endast räknar den del av runföljden som hör till rad 1 är även startraden i parti A på DR 4 Haddeby 4 kortare än de två övriga. Möjligen kan DR 30 Bække 2 nämnas, men skillnaden är liten ( $\operatorname{rad} 1$ är c:a $80 \mathrm{~cm}$ och rad $2 \mathrm{c}: \mathrm{a} 85 \mathrm{~cm}$ lång, egen mätning).

Ytterligare en resurs, radläge, som uttrycker framskjutenhet består i att starten för en rad antingen kan vara placerad lite högre upp alternativt lite längre ner än övriga rader i ett vertikalt radupplägg. Ofta gäller placeringen högt/lågt $\mathrm{i}$ förhållande till samtliga övriga rader i partiet, men ibland avviker radläget bara från majoriteten av de övriga raderna. Lägg märke till att vid bustrofedonupplägg är det avslutningen på de rader vars läsriktning löper uppifrån och ned som jämförs med placeringen av startradens början. Varianten där början på en rad befinner sig relativt lågt ner i ett parti kan kopplas till lässtart i följande fall: DR 29 Bække 1, ?DR 40 Randbøl, DR 143 Gunderup 1 (parti B), DR 248 Snoldelev, och DR 209 Glavendrup (C). Slutligen startar också den första av de två tolkade raderna på DR MLUHM1983-84;131 Lilla Köpinge längre ner jämfört med den följande om raderna ses vertikalt.

Alternativet att startradens början är placerad högre upp i ett parti finns på DR 143 (parti A), DR 202 Rønninge (men bara med någon centimeter, egen mätning), DR 250 Høje Tåstrup, DR 230 Tryggevælde (parti A), Ög 8 Kälvesten (A) och Ög N288 Oklunda (om de fyra raderna ses vertikalt). Även parti B på DR 209 Glavendrup utgör ett exempel. Dock är lässtart osäker här, men de två möjliga alternativen utgörs båda av rader som startar lite högre upp än de övriga i partiet. Vad gäller frekvens förekommer det något oftare att startradens inledning är placerad högre än de övriga, men alternativet lägre placering är nästan lika vanligt. Två av exemplen ovan ska kommenteras ytterligare. När det kommer till höjden på en av de båda möjliga startraderna i parti B $(\operatorname{rad} 6)$ på Glavendrupstenen, menar Ludvig Wimmer (1895-1908, 2: 378) att radens början placerats högre upp för att undvika en av de skålformade fördjupningarna på stenen. Dock har runor huggits över liknande fördjupningar på andra ställen (t.ex. är r-runan i runaR i rad 11 ristad över en jämförbar grop, egen granskning), varför detta inte måste vara enda skälet. Oavsett motiv kvarstår emellertid intrycket att placeringen av rad 6 avviker visuellt från majoriteten av partiets övriga rader. Liknande förhållande gäller för Oklundahällen vars startrad är placerad något högre upp. Man kan hävda att startpunkten är styrd av stenytans form (en spricka i hällen), men intrycket kvarstår att raden där lässtart återfinns avviker visuellt. I båda fallen bedömer jag 
alltså att resursen resulterar i ett visst visuellt erbjudande om läsordning, även om det kan finnas andra faktiska motiv bakom placeringen.

Ännu en resurs som uttrycker framskjutenhet är runtäthet; runorna är placerade relativt glest alternativt relativt tätt i startradens inledning jämfört med övriga rader (ibland men inte alltid kombinerat med resursen runstorlek). Jag jämför i första hand inledningen av raderna, eftersom det främst verkar vara där som relevanta skillnader uppträder. I flera av exemplen är resursen otydlig. Glesare runor är den mest frekventa varianten och kan kopplas till lässtart i ett parti på DR 2 Haddeby 2 (parti A), DR 4 Haddeby 4 (A; marginellt, och inte inledningsvis), DR 209 Glavendrup (A), ?DR 356 Sölvesborgs kyrka, Ög 136 Rök (A) och i någon mån på DR 230 Tryggevælde (A). Ett exempel finns också på det omvända; tätare runor kan kopplas till lässtart på DR 30 Bække 2 .

Vidare är skiljetecken (se annorlunda terminologi i Åkerström 2013, $14 \mathrm{f}$.) en resurs som tycks kunna uttrycka framskjutenhet i ett inskriftsparti. Denna resurs finns i två varianter; antingen är alla rader utom startraden utmärkta med skiljetecken eller är endast startraden markerad. Det förstnämnda gäller DR 29 Bække 1 och det sistnämnda parti A på lösföremålet Hs 7 Forsa kyrka (även rad 2 inleds här med skiljetecken men detta har en mindre komplicerad form jämfört med det tecken som inleder kompositionens startrad). Nämnas ska också parti A på DR 143 Gunderup 1. Här inleds startraden med ramlinje och skiljetecken, medan den andra radens slut (raderna löper bustrofedon) endast markeras med skiljetecken. Även raderna i B-partiet på DR 143 markeras endast med skiljetecken.

Resursen radavgränsning uttrycker framskjutenhet kopplad till lässtart och innebär att vissa rader i ett parti markeras med någon typ av avgränsning samtidigt som andra saknar detta. Resursen finns i två varianter där den mest frekventa innebär att den/de inledande raden/ raderna avgränsas längsmed båda sidor (antingen genom en ramlinje, objektets kant eller en annan rad placerad intill), medan den avslutande raden saknar avgränsning längsmed en av sina sidor. Den mer infrekventa varianten innebär att förhållandet är det omvända. I följande kompositioner finns ett parti där raderna markeras enligt det mest frekventa mönstret: DR 189 Avnslev (parti A; dock baserat på en teckning), DR 143 Gunderup 1 (B), DR 209 Glavendrup (C), DR EM85;151B Ribe och Sm 144 Gursten (B). ${ }^{10}$ I de tre sistnämnda fallen är det fråga om partier där ramlinjer inte förekommer alls. Att den/de inledande

${ }^{10}$ Tre troliga belägg på radavgränsning, där läsordningen dock inte kan bestämmas helt på språklig grund, är DR 190 Helnæs, DR 192 Flemløse 1 och DR 209 Glavendrup (parti B). 
raden/raderna avgränsas genom objektets kant eller en intilliggande rad medan den avslutande raden saknar avgränsning längsmed en sida skulle därmed kunna sägas vara en följd av att den inledande raden ofta placeras längsmed höger eller vänster kant på ett objekt (se resursen placering av rad nedan). Det visuella intrycket att den avslutande raden "hänger i luften" medan de inledande raderna är avgränsade, finns dock även i dessa tre kompositioner. Endast ett (eventuellt) exempel på den mindre frekventa varianten av radavgränsning finns: Två (av fyra) rader på DR MLUHM1983-84;131 Lilla Köpinge är tolkade och dessa två läses efter varandra. Den första av dem saknar avgränsning längsmed en sida, medan den andra raden är avgränsad längsmed båda. Att den första raden är hela partiets startrad kan dock inte fastställas på språklig grund.

Slutligen är större grupp av rader en typ av resurs som kan kopplas till startrad i ett parti. I några fall urskiljs grupper av rader från varandra genom att vissa placeras vertikalt och andra horisontellt, och resursen ifråga innebär att man hittar lässtart i den grupp rader som tar upp störst yta (en omvänd variant finns det inte belägg på). På Ög N288 Oklunda finns lässtart i en av de fyra raderna lagda i samma riktning, inte i den enda rad som löper på tvären mot dessa. På Ög 136 Rök (parti A) finns lässtart i den större gruppen med åtta vertikala rader, inte i den mindre undertill på stenen med två horisontella rader.

Slutligen ska resursernas inbördes frekvensförhållande kort redogöras för. Det är stor skillnad på hur beläggen fördelar sig mellan varianterna inom de olika resurserna. Radlängd (varianten med längre startrad) är mest frekvent, tätt följd av runstorlek (varianten med större runor). Därefter placerar sig radläge, där varianten med en högre placering av startradens början är marginellt mer frekvent än en lägre placering. Runtäthet (varianten med glesare runor), radavgränsning (varianten med avgränsad startrad) och radlängd (varianten med kortare startrad) är något mindre frekvent. Runstorlek (varianten med mindre runor) och större grupp av rader är än mer infrekvent. Minst frekvent är runtäthet (varianten med tätt placerade runor), radavgränsning (varianten utan avgränsad startrad) samt skiljetecken (båda varianterna).

\section{Lässtart: Startparti}

Endast tre resurser urskiljs som uttrycker framskjutenhet kopplad till startparti i en komposition med fler än ett parti. Även här utgår dessa från storleksskillnader. Resursen större inskriftsparti innebär att startpartiet tar upp större plats jämfört med de övriga partierna. Resursen är frekvent bland flerparti-ristningarna: DR 2 Haddeby 2, DR 26 Læborg (marginellt), 
DR 41 Jelling 1, DR 230 Tryggevælde, DR 209 Glavendrup (parti A och B är större än parti C, se fig. 2), och Ög 8 Kälvesten. Däremot är de två partierna på DR 143 Gunderup 1 relativt lika till storleken (se fig. 1). Möjligen ska Ög 136 Rök nämnas; parti A är visserligen till ytan större än det följande parti $\mathrm{B}$ (kortsida) men något mindre än parti C (bredsida). Vad gäller lösföremålen finns en komposition, Hs 7 Forsa kyrka, vars startparti är större än nästföljande parti.

Den andra resursen är återigen runstorlek, som tidigare diskuterades i samband med lässtart i ett parti men som alltså även tycks kunna indikera hela kompositionens lässtart; om två partier befinner sig på varsin bredsida men den ena har större runor än den andra, då finns kompositionens lässtart i partiet med större runor. Iakttagelsen är dock osäker eftersom den endast bygger på två exempel, Òg 136 Rök (de inledande raderna i parti A består av större runor än de i parti C) och DR 209 Glavendrup (parti A har större runor än parti B). Varianten att mindre runor kan markera startparti finns inte belagd.

Även resursen radavgränsning kan knytas till lässtart i kompositioner med fler än ett parti. Här är det närvaron av avgränsande ramlinjer som uttrycker framskjutenhet. Den mest frekventa varianten består i att partiet som inleder kompositionen har ramlinjer medan det avslutande saknar sådana (objektets kant kan däremot fungera som avgränsning). Det gäller DR 209 Glavendrup, DR 230 Tryggevælde och DR 4 Haddeby 4. En omvänd variant finns möjligen också här, även om exemplet snarare handlar om antalet ramlinjer, inte att dessa helt saknas: På DR 41 Jelling 1 (se fig. 9) avgränsas det avslutande partiets rad med dubbla ramlinjer, medan det inledande partiets rader avgränsas med en enkel. Det faktum att de sistnämnda raderna inte är placerade precis bredvid varandra och därmed inte delar ramlinjer gör dock att de i någon mening kan sägas ha dubbla ramlinjer, även om en av dessa linjer alltså delas med en annan rad.

\section{Läsväg: Visuella resurser som uttrycker framskjutenhet, sambandskapande eller avgränsning}

En visuell analys har gjorts av vilka visuella resurser som tycks indikera den språkligt givna läsvägen i grupp 1. Inledningsvis diskuteras resurser som uttrycker (olika grad av) framskjutenhet, det vill säga betydelsen att det mest framskjutna elementet presenteras som viktigast och därför läses först medan de mindre framskjutna elementen läses senare. Därefter presenteras resurser som uttrycker sambandskapande (betydelsen att vissa element hör ihop), och till slut resurser som uttrycker avgränsning 
(betydelsen att vissa element inte hör ihop). Dessa tre betydelsesystem kan kopplas till funktionen läsväg genom att i de två förstnämnda fallen visa var denna går och i det sistnämnda var läsväg inte går. Vidare finns resurser som jag antar är knutna till läsväg genom konvention. Dessa diskuteras i ett avslutande avsnitt tillsammans med liknande typer av resurser som indikerar lässtart.

\section{Läsväg: Visuella resurser som uttrycker framskjutenhet}

Ovan presenterades resurser som uttrycker framskjutenhet kopplat till lässtart. I teorin har samtliga dessa resurser även med läsväg att göra; om ett element är framskjutet och kan knytas till lässtart finns det alltid ett annat element som är mindre framskjutet vilket bör läsas senare. Att grad av framskjutenhet är knuten till en specifik plats i läsordningen är emellertid mest påtaglig för resursen radlängd. Närmare bestämt handlar det om den variant av resursen där kantradernas längd är avgörande; $i$ den längre av de två kantraderna återfinns ofta partiets lässtart medan dess avslutning ofta finns i den kortare. Inskriftspartier där kantraden med lässtart är längre än den avslutande kantraden finns på DR 29 Bække 1, DR 202 Rønninge och på Ög 136 Rök (parti A; de vertikala raderna). Möjligen kan parti B på Sm 144 Gursten räknas som ett exempel, men längdskillnaderna här är små. ${ }^{11}$ Resursen utnyttjas emellertid inte alltid; exempel finns där samtliga rader i partiet är ungefär lika långa (t.ex. parti A på DR 41 Jelling 1, se fig. 9). Slutligen ska ett möjligt exempel på det motsatta nämnas; på Óg N288 Oklunda är startraden kortare än de övriga raderna med samma riktning (se fig. 8). Dock kan inte läsväg bestämmas på språklig grund mellan alla dessa rader. En förklaring till kantradernas betydelse är att kompositioner med vertikala rader vanligtvis läses från den ena kanten mot den andra (se placering av rad och radordning nedan), varför lässtart i första hand bör ha varit förknippad med en av kantraderna, inte med dem i mitten. De två kantradernas längd bör därför vara mest relevant för att markera lässtart respektive avslut, och så länge det finns en visuell skillnad mellan dessa två kan man anta att det finns ett starkt markerat erbjudande om läsordning i texten.

\footnotetext{
${ }^{11}$ Fler sannolika belägg på resursen finns på DR 190 Helnæs, DR 192 Flemløse 1 och på DR 209 Glavendrup (parti B; se fig. 2), men en fullständig ordning mellan raderna kan här inte bestämmas på språklig grund.
} 


\section{Läsväg: Visuella resurser som uttrycker sambandskapande}

Betydelsen sambandskapande är knuten till funktionen läsväg. Den mest frekventa resursen som uttrycker sambandskapande, närhet mellan rader, består i att rader i ett parti placeras bredvid varandra. I regel delar de också samma ramlinje. Utifrån den språkligt givna läsordningen ska sådana rader nästan alltid läsas efter varandra och resursen är alltså mycket frekvent. Det finns emellertid några exempel på motsatsen. I kompositioner med lässtart i en vertikal mittenrad går läsvägen först mot vänster, därefter ska raderna till höger om mittraden läsas (se placering av rad och radordning nedan). Mittenraden och raden till höger om denna läses alltså inte efter varandra trots att de angränsar visuellt.

I linje med närhet mellan rader skulle man kunna tänka sig en resurs som består av närhet mellan inskriftspartier, vilken alltså skulle signalera i vilken ordning partier ska läsas. I grupp 1 hittar jag emellertid endast ett fall där man säkert kan se detta (parti A-B på Ög 136 Rök), medan flera fall finns på det motsatta. På DR 4 Haddeby 4 angränsar parti A till parti C, men inte till B. En rad löper emellertid oavbrutet från parti A till parti B varför läsordningen framgår ändå. På DR 209 Glavendrup angränsar inte parti A och $B$ till varandra men båda är placerade intill parti C (se fig. 2), och på DR 230 Tryggevælde angränsar parti C till parti A men inte till parti B. Jag tolkar därför inte närhet mellan partier som en resurs, även om det är troligt att en sådan kan ha förekommit. Det finns exempelvis flera kompositioner med två partier vars rader är placerade kant i kant med varandra (t.ex. DR 143 Gunderup 1 se fig. 1 och Ög 8 Kälvesten). För att kunna säga huruvida detta avstånd är relativt kort eller långt behövs dock ett tredje parti till vilket avståndet kan jämföras, varför exemplen inte fungerar som belägg.

Vidare är närliggande startpunkt för rad, visuellt signalerad genom runornas orientering, en resurs som kan uttrycka sambandsskapande och detta kan knytas till läsväg mellan rader i ett parti. Särskilt gäller det radupplägg där läsriktningen löper bustrofedon istället för nedifrån och upp i samtliga rader. I bustrofedonupplägg befinner sig början på nästa rad i direkt anslutning till slutet på den föregående (se t.ex. DR 209). Bustrofedonupplägg förekommer särskilt ofta i danska stenristningar (DR 4, DR 29 Bække 1, DR 143, DR 189 Avnslev, DR 190 Helnæs, DR 192 Flemløse 1, DR 202 Rønninge, DR 209 och ?DR 356 Sölvesborgs kyrka) men finns både i ristningar på lösföremål (DR MLUHM1983-84;131 Lilla Köpinge) och i svenska stenristningar (Ög 136 Rök). En annan variant av resursen finns på Ög 136. Här ansluter två rader till varandra i ungefär 90 graders vinkel (parti C, rad 22-23). Två partier (rad 10 i parti $\mathrm{A}$ och rad 11 i parti B) i samma komposition ansluter till varandra på ett liknande sätt. 
Man bör också kunna räkna med en resurs närliggande startpunkt för parti. I de två partierna på DR 143 löper raderna bustrofedon inte bara inom utan även mellan dessa (parti A: $\uparrow \downarrow$, parti B: $\uparrow \downarrow$ ) och riktningen för den ordning raderna läses i är densamma i parti A som i parti B, det vill säga från raden till vänster mot den till höger. Närliggande startpunkt för parti innebär alltså att den ordning raderna läses i har samma riktning i två på varandra följande partier om raderna löper bustrofedon både inom och över partigränsen. Endast ett belägg på resursen finns i grupp 1, men eftersom exempel finns på att ett omvänt förhållande (se avstånd till partiets startpunkt nedan) kan knytas till en läsordningsfunktion kan det vara motiverat att göra samma sak med närliggande startpunkt för parti.

\section{Läsväg: Visuella resurser som uttrycker avgränsning}

Medan betydelsen sambandskapande visar på en viss läsväg kan betydelsen avgränsning istället markera var läsväg inte finns. En frekvent resurs som uttrycker avgränsning är avstånd mellan rader. Resursen består i att rader inom ett parti inte är placerade intill varandra, vilket signalerar att de inte ska läsas efter varandra (undantag finns dock i radupplägg med lässtart i en mittrad, se nedan). Oftast är resursen helt enkelt utformad så att rader som inte ska läsas efter varandra separeras visuellt av andra rader. I något fall är avståndet i form av oristad yta, som på lösföremålet DR MLUHM1983-84;131 Lilla Köpinge; två rader som ska läsas efter varandra ligger intill varandra medan kompositionens två återstående rader finns en bit ifrån. I brist på belägg urskiljs dock inte en resurs som innebär att ett avstånd mellan vissa partier visar var läsväg inte går (se ovan om närhet mellan partier).

Det finns exempel på att grupper av rader i samma parti separeras genom riktning; några rader är placerade vertikalt och andra horisontellt. En sådan resurs olika radriktning är knuten till läsordning genom att dessa grupper läses som separata enheter; de horisontella läses för sig och de vertikala för sig. Endast ett exempel finns dock på detta i grupp 1, nämligen i parti A på Ög 136 Rök. Eftersom radupplägget ifråga är ett så framträdande visuellt drag och har en så otvetydig koppling till läsväg tolkas det som en resurs trots detta.

Ytterligare en resurs som uttrycker avgränsning är avstånd till radens startpunkt. Eftersom en omvänd variant, närliggande startpunkt för rad (se ovan) är välbelagd, urskiljs resursen trots att bara två exempel finns i grupp 1: DR 209 Glavendrup (parti A) och DR 4 Haddeby 4 (A). Nämnas kan också att fler exempel finns i det senvikingatida materialet (se t.ex. Moltke i $D R$, Text, sp. 822 f. och Grønvik 1981, 132-134). I parti A på DR 209 finns fyra 
rader (och en femte mycket kort som inte berörs vidare här; se fig. 2). De löper $\uparrow \downarrow \uparrow \uparrow$ och ordningen mellan de två mittersta raderna går att bestämma på språklig grund; först läses den högra och sedan den till vänster. De två raderna längst till höger som båda löper nedifrån och upp läses alltså inte efter varandra, utan läsvägen går istället mot den rad som löper bustrofedon. Samma fenomen finns i parti A på DR 4 ( $\downarrow \uparrow \uparrow$ som läses i ordningen 2-13). ${ }^{12}$ I denna typ av radupplägg indikerar alltså ett större avstånd till nästa rads startpunkt vilka rader som inte ska läsas efter varandra. Det finns emellertid även exempel på kompositioner där läsriktningen i två rader löper åt samma håll medan övriga rader löper bustrofedon utan att detta måste betyda att dessa två rader inte läses efter varandra: parti B på DR 209 ( $\downarrow \downarrow \uparrow \downarrow \uparrow \uparrow)$, DR 190 Helnæs och DR 192 Flemløse 1 (båda $\uparrow \downarrow \uparrow \uparrow)$. Ordningen mellan de rader som löper bustrofedon och raden längst till höger kan emellertid inte bestämmas på språklig grund i något av dessa tre fall, men enligt den allmänt vedertagna ordningen läses raderna från vänster mot höger. Det är troligt att den avgränsande betydelsen som uttrycks här är knuten till andra funktioner än läsordning; $i$ alla tre exemplen är innehållet i raden längst till höger av en annan typ än i de övriga raderna.

En resurs som avgränsar partier från varandra är avstånd till partiets startpunkt. Resursen kan ses som en omvänd version av närliggande startpunkt för parti (se ovan) och innebär att två partier angränsar till varandra visuellt samtidigt som deras respektive rader löper bustrofedon, men utan att denna bustrofedonordning sträcker sig över partigränsen.Läsriktningen i de två rader som ligger kant i kant går alltså åt samma håll. Till skillnad från närliggande startpunkt för parti där den sambandskapande betydelsen indikerar att dessa rader ska läsas efter varandra, visar avstånd till partiets startpunkt att de tvärtom inte ska läsas efter varandra, även om själva partierna alltså läses efter varandra i båda fallen. Resursen förekommer mellan parti B och C på DR 209 Glavendrup, där raderna i parti B läses från vänster mot höger och de i parti $C$ från höger mot vänster. Ytterligare ett exempel finns på DR 189 Avnslev (se fig. 3) där raderna i parti A enligt de bevarade teckningarna läses från vänster mot höger. Läsordningen för parti B kan inte bestämmas på språklig grund, men den rad som ligger kant i kant med rad 1 i parti A läses alltså inte direkt efter denna.

\footnotetext{
${ }^{12}$ Här tas inte hänsyn till att lässtart för rad 1 finns ett stycke upp mellan ramlinjerna. Den nedersta delen (endast en runa, u) räknas som en egen rad ( $\operatorname{rad} 3$ i tablå 3 ) eftersom runans läsriktning (uppifrån och ned) skiljer sig från runföljden i rad 1 (nedifrån och upp). Runan har alltså samma läsriktning som raden längst till vänster ( $\operatorname{rad} 2)$ och läses direkt efter denna enligt den språkligt givna läsordningen.
} 


\section{Konventionaliserad lässtart och läsväg}

I det följande ska sådana resurser diskuteras vilka inte uttrycker betydelserna framskjutenhet, sambandskapande eller avgränsning, utan som istället antas vara direkt knutna till läsordningsfunktioner genom konvention.

Först ska resursen läsriktning $i$ rad diskuteras. Den fungerar på så sätt att i vertikala radupplägg utgörs startraden i princip alltid av en rad med läsriktning nedifrån och upp (eller från vänster mot höger om raden ses horisontellt), vilket visuellt signaleras genom runornas riktning. På Ög 136 Rök finns emellertid exempel på att den inledande raden i ett parti (parti D) istället löper uppifrån och ned. Även DR 4 Haddeby 4 ska nämnas i detta sammanhang. Den sista raden i parti A går nedifrån och upp och löper oavbruten över stenens topp och över i baksidans parti B, där den följaktligen utgör den inledande raden samtidigt som den löper uppifrån och ned. Men inte heller här är det alltså fråga om hela kompositionens lässtart utan om inledningen av parti B. ${ }^{13}$ På både Ög 136 och DR 4 löper den rad som inleder hela kompositionen nedifrån och upp. Jag urskiljer därför inte en variant av resursen läsriktning $i \mathrm{rad}$ som skulle innebära att startraden kan löpa uppifrån och ned, utan tolkar beläggen som att resursen i flerparti-ristningar i första hand handlar om hela kompositionens lässtart. Även bland de enradiga stenristningarna löper läsriktningen i startraden alltid nedifrån och upp. I några fall kan man emellertid diskutera åt vilket håll stenen har varit rest. I synnerhet DR 193 Flemløse 2, DR DKFyn51 Faaborg och N 140 Valby är exempel på stenar som utifrån radens placering på stenytan skulle kunna ha varit resta så att läsriktningen istället löper uppifrån och ned.

Ytterligare en resurs, placering av rad, kan kopplas till lässtart. Resursen innebär att i ett parti med vertikalt radupplägg återfinns startraden antingen längst till vänster, längst till höger eller $\mathrm{i}$ mitten. Lässtart $\mathrm{i}$ raden längst till vänster finns i följande partier: DR 2 Haddeby 2 (parti A), DR 30 Bække 2, DR 41 Jelling 1 (A), DR 143 Gunderup 1 (A och B), DR 189 Avnslev (A), DR 202 Rønninge, DR 248 Snoldelev, DR 250 Høje Tåstrup, Òg 8 Kälvesten (A), Ög 136 (A) samt på U 4 Björkö (förutsatt att raderna läses vertikalt och startraden löper nedifrån och upp). Ett lösföremål med lässtart i raden längst till vänster är DR EM85;151B Ribe. Lässtart i raden längst till höger finns i följande partier: DR 29 Bække 1, DR 209 Glaven-

${ }^{13}$ I tablå 3 och i den visuella analysen räknas det som här omnämns som startrad i parti B enbart till parti A. 
drup (parti C), ?DR 356 Sölvesborgs kyrka och Sm 144 Gursten (B), delar av chiffret på Ög 136 (D) och slutligen på Ög N288 Oklunda. Även lösföremålet DR MLUHM1983-84;131 Lilla Köpinge kan nämnas; två av fyra rader är tolkade och dessa två läses efter varandra, från raden till höger och mot vänster. Det går dock inte att bestämma huruvida hela partiets lässtart finns i raden till höger. Lässtart i mittenraden finns i följande partier: ?DR 40 Randbøl, DR 209 (parti A) och DR 230 Tryggevælde (A). Även i parti A på DR 4 Haddeby 4 finns lässtart i en mittenrad, men ett stycke upp mellan ramlinjerna som inledningsvis rymmer rad 3. Mest frekvent är alltså lässtart i raden längst till vänster, därefter i den till höger medan lässtart i mittenraden är infrekvent. Dessutom är lässtart i raden längst till vänster förmodligen ännu mer frekvent än vad som framgår ovan. Det finns ytterligare fem ristningar där lässtart visserligen inte har kunnat bestämmas på språklig grund men däremot en läsväg från vänster mot höger i delar av kompositionen, vilket med utgångspunkt i resursen radordning (se vidare nedan) visar att lässtart troligen finns i raden längst till vänster även här. Även de enradiga stenristningarna tycks följa mönstret. I de fall man kan uttala sig om var en vertikal rad finns i förhållande till stenens kant är den oftare placerad mot eller nära den vänstra kanten på skriftytan (DR 15 Øster Løgum, DR 144 Gunderup 2, DR 193 Flemløse 2, ${ }^{14}$ Òg 38 Boberg och N 2 Bjørneby), men några exempel finns också på att raden ligger mot högra kanten (DR 17 Starup, ?DR 191 Sønderby och N 209 Oddernes 1) eller är mer eller mindre centrerad till ytans mitt (Bo Peterson1992 Hoga och Bo KJ80 Rävsal). Vad gäller lösföremål med en rad är denna oftast placerad centrerat eller täcker hela ytan. Belägg på rader placerade mot en kant är fördelade ungefär lika med avseende på höger-vänster-orientering.

Kombineras resurserna läsriktning $i$ rad och placering av rad kan man specificera platsen för lässtart inom ett parti med ett vertikalt radupplägg, nämligen nedre vänstra hörnet. Denna koppling bekräftas också om man går utanför mitt material. Øeby Nielsen $(2001,167)$ konstaterar att lässtart oftast finns nere till vänster bland de danska steninskrifterna och Bianchi $(2008,29)$ har sett samma tendens i steninskrifter från Kronobergs län. I sin undersökning av senvikingatida steninskrifter från Uppland och Södermanland nyanserar Bianchi (2010, 68-70, 73-78) dock denna slutsats; han undersöker lässtart i förhållande till del av rundjuret, inte till en absolut position på ristningsytan. I ristningar med en sammanhållen slinga hittar

${ }^{14}$ Eftersom startraden hamnar nära marken om stenen reses så att startradens läsriktning löper nedifrån och upp skulle man möjligen kunna diskutera huruvida stenen i själva verket varit vänd åt andra hållet. 
Bianchi lässtart i rundjurets vänstra del, även om dess absoluta position alltså ibland kan vara till höger på ristningsytan.

Resursen radordning kan kopplas till läsväg i vertikala radupplägg i ett parti. Resursen innebär att läsväg går rad för rad mot höger, alternativt rad för rad mot vänster eller, då lässtart finns i en mittenrad, först mot vänster och sedan mot höger. Resursen har ett samband med placering $a v$ rad; om lässtart finns i raden längst till vänster löper läsvägen rad för rad mot höger, men om lässtart finns i raden längst till höger går läsvägen istället mot vänster. Då lässtart finns i mittenraden löper läsvägen först mot vänster för att sedan fortsätta i raden till höger om startraden. Beläggen för dessa två resurser är alltså desamma, med undantag av att det finns ytterligare fem exempel på partier (DR 110 Virring, DR 190 Helnæs, DR 192 Flemløse 1, DR 209 Glavendrup parti B och Ög 136 Rök C) där lässtart inte kan bestämmas men där läsvägen från vänster mot höger delvis är språkligt given. ${ }^{15}$ Totalt kan en läsväg från vänster mot höger alltså konstateras helt eller delvis i 17 kompositioner medan bara sex stycken har en läsväg mot vänster och fyra en ordning där raderna läses först mot vänster och sedan mot höger. Läsväg mot höger är alltså mycket mer frekvent än de övriga varianterna.

Hittills har endast vertikala radupplägg diskuterats. Eftersom beläggen är få på rader som med säkerhet ligger horisontellt är det emellertid svårt att säga något bestämt om sådana varianter av placering av rad respektive radordning. Det finns emellertid ett säkert exempel, de horisontala raderna i parti A på Ög 136, på att lässtart hittas i översta raden med en läsväg uppifrån och ned. Ett säkert exempel på en läsväg uppifrån och ned, men med osäker lässtart, kan konstateras i parti C i samma komposition. Beläggen på horisontella radupplägg kan sättas i samband med de vertikala. Vrider man kompositioner med horisontella rader med lässtart i översta raden och läsväg uppifrån och ned och betraktar dem vertikalt med läsriktning nedifrån och upp i startraden, finns lässtart i den vänstra raden och läsvägen går mot höger. Ett tillägg till hur resurserna placering av rad respektive radordning fungerar kan alltså göras; det verkar inte $\mathrm{i}$ första hand handla om absolut position respektive riktning på ristningsytan utan snarare, i likhet med Bianchis (2010) resultat (se ovan), om en viss del av och en viss riktning inom själva kompositionen.

I kompositioner med fler än ett parti kan en resurs, placering av parti, knytas till hela kompositionens lässtart. Resursen finns i två varianter:

${ }^{15}$ En läsordning där ordningen raderna läses i växlar riktning är mindre troligt, p.g.a. hur de delar av läsvägen som är möjlig att bestämma på språklig grund ser ut.

Futhark 9-10 (2018-2019) 
lässtart återfinns i partiet längst till vänster alternativt i det till höger. Lässtart i partiet längst till vänster gäller för fyra kompositioner: DR 26 Læborg, DR 143 Gunderup 1, DR 209 Glavendrup och Ög 8 Kälvesten. Även på DR 230 Tryggevælde och Ög 136 finns kompositionens startparti till vänster i den meningen att fortsättning finns till höger, men eftersom kompositionen består av ristningar på alla sidor av stenen befinner sig startpartiet samtidigt både till vänster och till höger om andra partier i kompositionen. Endast ett belägg (DR 2 Haddeby 2) finns på alternativet lässtart i partiet till höger och denna variant är alltså betydligt mindre frekvent. Vidare kan resursen partiordning kopplas till läsväg i flerpartikompositioner. Resursen innebär att läsväg går från vänstra partiet mot det till höger och är belagd på DR 26, DR 143, DR 230, Ög 8 och mellan parti A och B på Ög 136. Även här finns en mindre frekvent variant av resursen, läsväg från höger mot vänster, belagd på DR 2 och mellan parti B och C på DR 209.

Resurserna radordning och partiordning är nära förbunden med närhet mellan rader, det vill säga rader som ligger i anslutning till varandra läses efter varandra. Anledningen till att här urskilja olika resurser är att närhet mellan rader tar fasta på den sambandskapande betydelsen, medan radordning och partiordning snarare handlar om riktningen raderna respektive partierna läses i.

\section{Fallbeskrivningar}

I resultatredovisningen ovan har utgångspunkten varit den enskilda resursen. I det följande ska istället några ristningar ur grupp 1 diskuteras med syfte att illustrera hur resurserna kan fungera i kombination med varandra.

Det är inte alltid samma visuella resurser som erbjuder en läsordning, och det varierar också hur många som samverkar parallellt för att indikera en viss ordning. På DR 29 Bække 1 (se fig. 4) förekommer exempelvis inte den mest frekventa varianten av resursen placering av rad (lässtart i vänster kantrad), utan startraden finns längst till höger. Flera andra resurser som radlängd(den frekventa varianten), radläge samt skiljetecken har emellertid använts för att markera den ovanliga lässtarten. Genom att flera resurser på detta sätt samverkar rymmer texten därmed ett starkt markerat erbjudande om lässtart, trots den mindre frekventa varianten av placering a v rad. Ytterligare ett exempel är ?DR 40 Randbøl (se fig. 5). Också här följer resursen placering av rad ett mindre frekvent mönster; lässtart finns i mittraden istället för i raden längst till vänster. Den ovanliga lässtarten markeras visuellt mycket tydligt med den frekventa varianten av 
radlängd (raden är betydligt längre). Däremot finns i en komposition som den på DR 250 Høje Tåstrup (se fig. 6), där resursen placering av rad är av den frekventa varianten (lässtart i vänstra raden), inte lika tydligt utformade kompletterande resurser. Runorna i startraden är bara något större och raden är något kortare (den mindre frekventa varianten av radlängd). Det varierar alltså hur tydligt en viss visuell resurs är utformad. När det exempelvis kommer till runstorlek eller radläge skiftar det hur mycket runornas storlek skiljer sig åt respektive hur stor höjdskillnaden är. Till exempel har DR 248 Snoldelev (se fig. 7) lässtart i raden till vänster, vilket också markeras med betydligt större runor. Genom den tydliga utformningen av det mest frekventa alternativet av runstorlek samt en frekvent variant av placering av rad finns här ett mycket starkt markerat visuellt erbjudande om en viss läsordning.

I andra kompositioner resulterar resurserna istället $\mathrm{i}$ ett svagt markerat erbjudande om läsordning. På till exempel Òg N288 Oklunda (se fig. 8) är resursen placering $a v$ rad av en mindre frekvent variant: startraden är längst till höger. Även den mycket infrekventa varianten av resursen runstorlek har använts (startraden skiljer sig från de övriga genom att ha något mindre runor). Vidare finns en infrekvent variant av radlängd (startraden är kortare än de övriga som är placerade i samma riktning) kombinerat med radläge (startradens början är placerad något högre upp).

Slutligen är gruppen enradiga kompositioner exempel på att fler resurser än vad som strängt taget är nödvändigt erbjuder läsordning samtidigt. I teorin skulle man kunna tänka sig att i denna typ av komposition där startraden inte måste markeras visuellt skulle detta heller inte ha gjorts. Så är emellertid inte fallet. De enradiga stenristningarna följer nämligen både i fråga om läsriktning $i$ rad och placering av rad samma mönster som de flerradiga; i startraden löper runorna nedifrån och upp och radens placering är ofta till vänster på ytan. Det bör kunna tolkas som att resurserna ifråga var väletablerade under tidig vikingatid.

\section{Sammanfattning och diskussion}

I tablå 1 sammanfattas resultatet från den visuella analysen av grupp 1. För varje resurs anges till vänster vilken typ av visuellt element det gäller och till höger redovisas vilken betydelse som (eventuellt) uttrycks samt vilken läsordningsfunktion denna är knuten till.

Vid en geografisk jämförelse måste hänsyn tas till proportionerna mellan danska och svenska flerradiga ristningar i grupp 1 (20 danska och 7 svenska). Det är alltså visserligen många danska belägg på de flesta resurser 
Tablå 1. Översikt över de urskilda resurserna, vilka element de förekommer i, vilken betydelse de (eventuellt) uttrycker samt till vilken läsordningsfunktion de kan knytas. Då flera varianter av en resurs förekommer och en är mer frekvent än den/de andra markeras den mest frekventa med versaler.

\begin{tabular}{|c|c|c|c|}
\hline Visuellt element & Resurs & Betydelse & Funktion \\
\hline Rad i ett parti & Runstorlek (STÖRRE/mindre) & \multirow{10}{*}{ 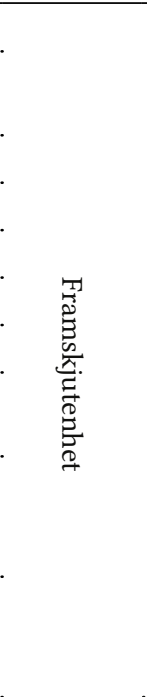 } & \multirow{10}{*}{ 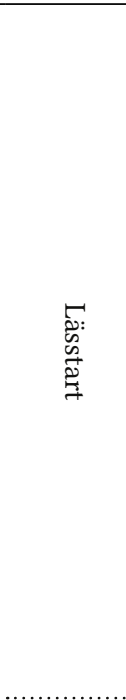 } \\
\hline $\begin{array}{l}\text { Parti i en flerparti- } \\
\text { komposition }\end{array}$ & Runstorlek (större) & & \\
\hline \multirow{5}{*}{ Rad i ett parti } & Radlängd (LÄNGRE/kortare) & & \\
\hline & Radläge (högre/lägre) & & \\
\hline & Runtäthet (GLESARE/tätare) & & \\
\hline & Skiljetecken (närvaro/frånvaro) & & \\
\hline & Större grupp av rader & & \\
\hline $\begin{array}{l}\text { Parti i en flerparti- } \\
\text { komposition }\end{array}$ & Större parti & & \\
\hline Rader i ett parti & $\begin{array}{l}\text { Radavgränsning (AVGRÄNSNING av } \\
\text { inledande rader/färre avgränsningar av } \\
\text { inledande rader) }\end{array}$ & & \\
\hline $\begin{array}{l}\text { Partier i en flerparti- } \\
\text { komposition }\end{array}$ & $\begin{array}{l}\text { Radavgränsning (AVGRÄNSNING av } \\
\text { rader i inledande partier/färre avgräns- } \\
\text { ningar av rader i inledande partier) }\end{array}$ & & \\
\hline \multirow{3}{*}{ Rader i ett parti } & Radlängd (kantradernas längd) & \multirow{4}{*}{ 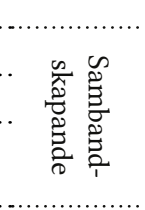 } & \multirow{8}{*}{ 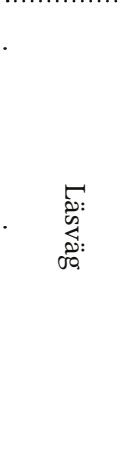 } \\
\hline & Närhet mellan rader & & \\
\hline & Närliggande startpunkt för rad & & \\
\hline $\begin{array}{l}\text { Rader i partier i en } \\
\text { flerparti-komposition }\end{array}$ & Närliggande startpunkt för parti & & \\
\hline \multirow{3}{*}{ Rader i ett parti } & Avstånd mellan rader & \multirow{4}{*}{ 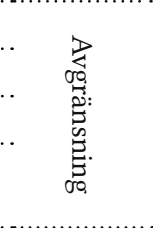 } & \\
\hline & Olika radriktning & & \\
\hline & Avstånd till radens startpunkt & & \\
\hline $\begin{array}{l}\text { Rader i partier i en } \\
\text { flerparti-komposition }\end{array}$ & Avstånd till partiets startpunkt & & \\
\hline Rad i en komposition & Läsriktning i rad & \multirow{5}{*}{ I } & \multirow{3}{*}{ 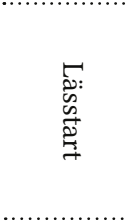 } \\
\hline Rad i ett parti & $\begin{array}{l}\text { Placering av rad (VÄNSTER/höger/ } \\
\text { mitten) }\end{array}$ & & \\
\hline $\begin{array}{l}\text { Parti i en flerparti- } \\
\text { komposition }\end{array}$ & Placering av parti (VÄNSTER/höger) & & \\
\hline Rader i ett parti & $\begin{array}{l}\text { Radordning (MOT HÖGER/mot vänster/ } \\
\text { växlande riktning) }\end{array}$ & & \multirow{2}{*}{ 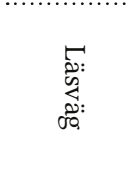 } \\
\hline $\begin{array}{l}\text { Partier i en flerparti- } \\
\text { komposition }\end{array}$ & Partiordning (MOT HÖGER/mot vänster) & & \\
\hline
\end{tabular}

Futhark 9-10 (2018-2019) 
men oftast inte fler än förväntat med tanke på denna snedfördelning. Ett par fall kan nämnas med proportionerligt sett många svenska belägg: Större grupp av rader finns till exempel i två svenska ristningar men inte i några danska (se dock DR NOR1988;5 Malt nedan), och på placering av rad samt radordning (varianten med startrad längst till höger och läsväg mot vänster) finns lika många exempel i danska som svenska stenristningar (3 vardera). Varianten med startrad till vänster och läsväg mot höger har däremot, utifrån sammansättningen av grupp 1, en förväntad fördelning mellan svenska och danska belägg, medan varianten med lässtart i en mittenrad och en växlande riktning för ordningen raderna läses i uteslutande finns i det danska materialet. Vidare finns endast danska belägg på radläge (varianten där startraden är placerad lägre än de övriga). Slutligen förekommer resurser knutna till bustrofedonupplägg (närliggande startpunkt för rad, närliggande startpunkt för parti, avstånd till radens startpunkt och avstånd till partiets startpunkt) i huvudsak i det danska materialet.

Att jämföra ristningar i sten med de på lösföremål är näst intill omöjligt eftersom endast tre flerradiga lösföremål ingår i grupp 1. Utifrån dessa tre runristningar tycks dock inte andra visuella resurser kopplade till läsordning förekomma på lösföremål jämfört med sten. Ett undantag finns emellertid; eftersom lösföremålens plats i rummet kan skifta är möjligheten att utnyttja en bestämd riktning som en visuell resurs begränsad. I analysen tillskrivs som ovan nämnts de ristningar på lösföremål och häll som ingår i grupp 1 en resurs (läsriktning $i$ rad) vilket ger raderna en bestämd riktning.

Att fler visuella ledtrådar om läsordning finns än de som presenterats ovan är troligt. Här ska kort nämnas ett par möjliga alternativ. För det första bör objektets placering ha haft betydelse då det kommer till flerparti-kompositioner på resta stenar. Den sida som är riktad åt det håll man i allmänhet närmade sig det ristade objektet kan ha uppfattats som den inledande; sidans placering uttrycker alltså framskjutenhet som kan kopplas till kompositionens lässtart. Att en sådan resurs inte övervägs här beror dels på att jag valt att begränsa undersökningen till att omfatta enbart det ristade objektet, inte dess omgivning, dels att det endast för ett fåtal ristningar i sten går att hitta uppgifter om hur de ursprungligen var resta. För det andra har avvikande skriftsystem eventuellt uttryckt betydelse knuten till läsordning. I undersökningsmaterialet återfinns avvikande skriftsystem exempelvis på Òg 136 Rök, DR 239 Gørlev 1, Ȯg 43 Ingelstad och eventuellt även på DR 263 Skabersjö och DR NOR1988;5 Malt. Något tydligt samband mellan avvikande skriftsystem och läsordning har jag emellertid inte kunnat hitta i det tidigvikingatida materialet och det tolkas därför inte som en resurs. 
Avslutningsvis ska nämnas att placeringen av runföljderna i rader, på olika sidor och på skilda objekt givetvis har stor relevans för läsordningen. Eftersom dessa enheter fungerar som utgångspunkt för studien urskiljs de dock inte som resurser här, trots att de med all säkerhet fungerat som sådana under tidig vikingatid.

\section{Visuellt erbjuden läsordning i tre exempelristningar}

I följande avsnitt ska exempel ges på hur man kan resonera kring läsordning endast utifrån textens visuella erbjudande. Tre ristningar ur grupp 2 diskuteras, närmare bestämt två på sten, Bo Boije4 Skee och DR NOR1988;5 Malt och en på ett lösföremål, U ANF1937;163 Björkö. Med utgångspunkt i de läsordningsprinciper som konstaterats i föregående avsnitt diskuteras tidigare läsordningar och nya förslag övervägs. Att just de nämnda runristningarna tas upp beror på att jag med hjälp av resultaten från föregående avsnitt tycker mig kunna säga något nytt om läsordningen i dessa fall. I linje med studiens syfte kommenterar jag inte konsekvenserna för det språkliga innehållet, inte heller försöker jag föreslå nytolkningar.

\section{Bo Boije4 Skee}

En runristning vars läsordning är svårbedömd är Bo Boije4 Skee (se fig. 10). Ingen övertygande tolkning av inskriften har presenterats. Stenen består av fyra ungefär lika breda sidor vilka alla är ristade, tre med en rad och en med två. Höjden är cirka $54 \mathrm{~cm}$ och bredden på dess fyra sidor är mellan 12 och $17 \mathrm{~cm}$ (egen mätning). Dessutom finns i toppen en avfasad yta med en kort rad (ip). Tidigare uttolkare har räknat med att raden ifråga hör till partiet som rymmer två rader, men man skulle möjligen kunna se det som ett eget parti; den avfasade ytan har nämligen kanter mot övriga sidor. Kanten mot sidan med partiet som rymmer två rader är dock relativt plan och därför räknar även jag ip-raden som en del av partiet med två rader. I den visuella analysen måste dock hänsyn tas till att raden på den avfasade ytan är visuellt separerad från de övriga två. Stenen är avslagen i botten och det går inte att säga hur långa raderna en gång varit. Jag utgår i det följande från att Skeestenen har varit rest och därmed bör ha haft en oristad fot. Därmed kan man, eftersom Sten Boije (1884, 274) menar att mycket lite är avslaget i ena änden, räkna med att där har stenens topp funnits, och den andra änden där ett större stycke är avslaget bör ha utgjort dess fot. I figur 10 är bilderna riktade med Boijes antagna 
topp uppåt. Nämnas ska också att runorna i raden i parti D föregås av vad som ser ut som ett större stycke oristad yta (c:a $10 \mathrm{~cm}$, egen mätning). Att de bevarade runorna skulle utgöra radens start motsägs dock av att dessa är mycket nedslitna. Ytan som föregår raden i D kan alltså en gång ha innehållit runor som idag inte går att urskilja. Runskriften translittereras (jag utgår från Bengt Lomans 1965 läsning så som denna redovisas i Samnordisk runtextdatabas; lägg märke till att teckningen i fig. 10 inte på alla punkter stämmer överens med denna läsning):

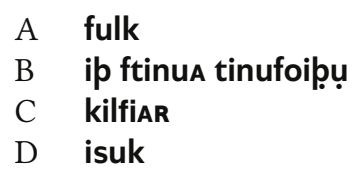

De tre raderna i parti B benämns i det följande $\mathbf{i}-\mathbf{f}$ - respektive $\mathbf{t}$-raden.

\section{Tidigare forskning}

Flera läsordningsförslag finns. George Stephens $(1874-1879,173)$ läser partierna i ordningen A-C-D-B och raderna i parti B i ordningen $\mathbf{f}-\mathbf{i}$-t. Val av lässtart för hela kompositionen motiverar Stephens (s. 167) med: "den storskrifna del, som börjar långt ned". Stephens läser de tre partierna med de största runformerna först och det verkar därmed som om han (i någon mån) följer den visuella resursen runstorlek; kompositioners startparti kan ibland markeras med större runor. Jag är dock osäker på vad Stephens menar med att delen "börjar långt ned"; raden i parti A startar i toppen och läses nedåt. Vad gäller läsväg menar Stephens (s. 172) att objektets sista sida många gånger rymmer mer inskrift eftersom ristaren ofta har mer kvar att skriva; alltså bör parti B avsluta. Han motiverar $($ s. 167, 172) även läsvägen utifrån möjligheten till en språklig tolkning; i parti A ser han ett namn och eftersom C inleds av en k-runa kan Stephens argumentera för att partiet en gång inletts av auk följt av ytterligare ett namn. Boije (1884, 276) följer Stephens läsordning, medan Arthur Nordén (1937, 148 f.) väljer ordningen A-D-C-B (i-f-t). Nordén motiverar sin läsordning utförligt. Han menar att i parti $A, C$ och D är runorna av samma storlek och på ett jämnt avstånd från varandra, medan de i parti B är "ojämna i storleken och oroligt placerade på ytan" (s. 148). Parti B utgör därmed kompositionens avslutning enligt Nordén. Av parti A, C och D är A "[j]ämnast i utförandet och störst i måttet" enligt Nordén (s. 148) och han bedömer därför att kompositionens start finns här. Även Nordén följer alltså resursen runstorlek samt ett visuellt drag som jag inte har tagit upp ovan: runornas utförande. Efter parti A läser han parti för parti mot vänster (D-C-B), det 
vill säga han följer en variant av resursen partiordning som är infrekvent i grupp 1. Vad gäller lässtart i parti B vill Nordén (s. 148 f.) "[m]ed hänsyn till runornas mått och placering" läsa raden i på den avfasade delen först, därefter $\operatorname{rad} \mathbf{f}$ och till sist $\operatorname{rad} \mathbf{t}$ med mindre runor. Att $\operatorname{rad} \mathbf{f}$ inleds med större runor än rad $\mathbf{t}$ menar Nordén beror på att ristaren inte planerat en så lång inskrift då ristningen inleddes. Även om Nordén alltså utgår från ristarens perspektiv är den resurs han följer för att bestämma lässtart $\mathrm{i}$ parti B runstorlek ("runornas mått"). Det är oklart vilken typ av visuellt drag Nordén avser med formuleringen "runornas [...] placering". Det kan knappast röra sig om resursen läsriktning $i \mathrm{rad}$; endast rad f löper nedifrån och upp och denna rad läses som rad två i partiet. Thomas Birkmann (1995, 340) följer Nordéns läsordning, medan Loman $(1965,53$ f.) framförallt modifierar Nordéns läsning av runtecknen. Loman (s. 53) anmärker också på runornas utförande: "runorna är placerade jämt och rakt på tre sidor, men är mera ojämnt formade på den fjärde [här parti B]". Bugge (18911903, 84, 377) tar upp Skeestenens inskrift men kommenterar inte läsordningen mellan partierna. För de tre linjerna i parti B presenterar han en tolkning som verkar förutsätta ordningen $\mathbf{t}$-i-f. Rad $\mathbf{t}$ läser han från mitten och ut mot båda sidor, vilket inte stöds av runornas riktning. Det framgår inte vilka visuella drag Bugge eventuellt har utgått från.

\section{Lässtart och läsväg i parti $B$}

Här ska läsordningen i parti B med de tre raderna $\mathbf{f}, \mathbf{t}$ och $\mathbf{i}$ diskuteras. Den mest frekventa varianten av resursen runstorlek indikerar att lässtart antingen finns i rad $\mathbf{f}$ eller i rad $\mathbf{i}$; runorna i rad $\mathbf{f}$ är mellan cirka 8 och $10 \mathrm{~cm}$ höga och i rad $\mathbf{i}$ är de cirka 9,5 respektive $10 \mathrm{~cm}$. Runorna i rad $\mathbf{t}$ är däremot bara mellan cirka 5 och $9 \mathrm{~cm}$ (egen mätning). Det ska dock nämnas att kanten mot vilken topparna på $\mathbf{t}$-radens runor angränsar är skadad, varför vissa av runorna kan ha varit högre. Den mest frekventa varianten av radlängd pekar mot att lässtart inte finns i den korta i-raden. Vilken av f- och t-raden som varit den längsta går dock inte att säga. Resursen placering av rad finns i flera varianter men den mest frekventa är att lässtart är knuten till raden längst till vänster, vilket erbjuder lässtart $\mathrm{i}$ f. Läsriktning i rad innebär att kompositionens (och nästan alltid partiets) lässtart finns i en rad vars läsriktning löper nedifrån och upp vilket endast $\operatorname{rad} \mathbf{f}$ gör i parti B. Sammantaget finns det starkast markerade erbjudandet om lässtart alltså i rad f.

Läsväg från rad f erbjuds genom radordning; om startrad finns i vänstra raden går läsvägen mot raden till höger, alltså rad t . Även resursen närliggande startpunkt för rad indikerar en sådan läsväg då raderna $\mathbf{f}$ och $\mathbf{t}$ 
löper bustrofedon. Frågan är dock hur i-raden ska passas in i detta. Jag har inga paralleller till B-partiets typ av radupplägg i grupp 1. Möjligen kan resursen närhet mellan rader vara en ledtråd. Den avfasade del där $\operatorname{rad} \mathbf{i}$ finns är vinklad så att den ligger "mellan" parti A och f-raden i B, vilket skulle kunna tyda på att om man antar en läsväg $\mathrm{A}-\mathrm{B}$ bör i-raden inleda parti B eftersom denna är placerad närmast A. B-partiets läsordning skulle då bli i-f-t. Detta motsägs dock av att flera resurser pekar mot att B-partiets lässtart är i rad f. En möjlighet är dock att betrakta i-raden som ett separat parti. Ordningen $\mathrm{A}-\mathbf{i}-\mathrm{B}(\mathbf{f}-\mathbf{t})$ skulle i så fall låta $\mathrm{B}$-partiet inledas av $\mathbf{f}$-raden. Det ska nämnas att jag endast har kunnat belägga resursen närhet mellan rader, det vill säga resursen gäller rader som är placerade nära varandra $\mathrm{i}$ samma inskriftsparti, inte partier som är placerade nära varandra, men det är inte osannolikt att även det sistnämnda kan ha förekommit (se ovan). Mot läsordningen $\mathrm{A}-\mathbf{i}-\mathrm{B}(\mathbf{f}-\mathbf{t})$ talar att raden i A och rad $\mathbf{f}$ löper bustrofedon (läsväg erbjuds alltså mellan dem genom närliggande startpunkt för rad), medan raden i $\mathrm{A}$ och rad $\mathbf{i}$ båda löper uppifrån och ned.

Om hänsyn i första hand tas till läsriktningen i rad i kan man tänka sig ordningen $\mathbf{f}$-i-t. Resursen närliggande startpunkt för rad skulle nämligen kunna indikera (även om någon exakt parallell till detta upplägg inte finns i grupp 1) läsordningen $\mathbf{i}-\mathbf{t}$; rad $\mathbf{i}$ har samma läsriktning som rad $\mathbf{t}$ och dess radslut finns därför i anslutning till början av rad $\mathbf{t}$. Ordningen har den fördelen att man kan låta rad $\mathbf{f}$ inleda parti B.

Man kan alltså hitta stöd i de visuella resurserna för Stephens alternativ $\mathbf{f}-\mathbf{i}-\mathbf{t}$ och möjligen även för Nordéns i-f-t. Nordén läser dock inte parti A före $B$, vilket jag menar är en förutsättning för att det ska vara motiverat att låta i-raden utgöra lässtart i parti B. Eftersom det mest påtagliga resultatet vad gäller B-partiets läsordning är att det finns ett starkt markerat erbjudande om lässtart i $\mathbf{f}$-raden menar jag att rad $\mathbf{i}$ (om denna ska räknas till parti B) bör läsas direkt efter rad $\mathbf{f}$ och därefter rad $\mathbf{t}$, alltså $\mathbf{f}-\mathbf{i}-\mathbf{t}$. Det bör emellertid poängteras att ingen självklar plats finns för rad i utifrån de visuella resurser som urskilts utifrån grupp 1.

\section{Kompositionens lässtart}

Två konkurrerande erbjudanden om lässtart för hela kompositionen finns i rad $\mathbf{f}$ i parti B respektive i parti D. Möjligen består det sistnämnda alternativet av ett något starkare markerat erbjudande.

Resursen större parti, som innebär att lässtart finns i det till ytan största partiet, tycks i första hand erbjuda B som startparti. Det går tyvärr inte längre att avgöra hur långa raderna har varit, men bredden på partierna går att jämföra. Parti A är mellan cirka $10 \mathrm{och} 11 \mathrm{~cm}$ brett (den kortare 
f-runan är troligen inte bevarad helt), C är mellan cirka 10,5 och $13 \mathrm{~cm}$ och D mellan 13 och $15 \mathrm{~cm}$. Den del av parti B som har två rader i bredd är mellan cirka 12 och $17 \mathrm{~cm}$ bred (egen mätning). Störst element, om än inte med mycket marginal, är alltså parti B. Här finns därmed ett svagt markerat erbjudande om lässtart. Slutsatsen är dock på grund av stenens skador mycket osäker; om raderna i parti $\mathrm{B}$ en gång har varit mycket kortare än de i övriga partier skulle förmodligen den lilla skillnaden i bredd inte uppväga intrycket av att parti B utgör ett mindre element. Det ska också nämnas att även om $\mathrm{D}$-partiet är något mindre än $\mathrm{B}$, upplevs det större på grund av de stora runformerna. Möjligen erbjuds alltså lässtart även i parti D genom större parti.

För lässtart i parti B talar möjligen ytterligare en faktor; visuella resurser som uttrycker framskjutenhet och kan kopplas till lässtart tycks ofta utmärkas av att de får elementet ifråga att avvika visuellt från de övriga i kompositionen. Om man räknar med en sådan överordnad princip öppnar det för möjligheten att det på ett enskilt ristningsobjekt kan förekomma mer eller mindre unika visuella drag som indikerar lässtart genom att elementet ifråga avviker från de övriga inom samma komposition. Överfört på Skeestenen kan detta betyda att kompositionens lässtart hittas i parti B; radupplägget avviker här från de övriga tre som å andra sidan liknar varandra.

Resursen runstorlek kan kopplas till kompositionens lässtart genom att då ett objekt har ristning på två bredsidor erbjuds lässtart i partiet med störst runformer. Skeestenens alla fyra sidor är dock relativt lika till sin storlek varför inga distinkta bredsidor finns. Skulle man ändå låta runstorlek indikera kompositionens lässtart erbjuds en sådan i parti D där de största runformerna finns (mellan c:a 13 och $15 \mathrm{~cm}$, egen mätning). Nordéns $(1937,148)$ påstående om att parti A är störst stämmer alltså inte.

Resursen läsriktning $i$ rad är som tidigare nämnts knuten till hela kompositionens lässtart i ristningar med fler än ett inskriftsparti. På Skeestenen skulle detta innebära att det finns ett erbjudande om lässtart för kompositionen antingen i rad f (i parti B) eller i parti D; det är endast dessa raders läsriktning som löper nedifrån och upp. Varken Stephens eller Nordén, som båda antar att kompositionens start finns i parti A, följer denna resurs.

Slutligen ska resursen runtäthet kommenteras. I grupp 1 finns endast belägg för att resursen indikerar startrad i ett parti, inte startparti i en komposition. Skulle man ändå räkna med att resursen även gäller kompositionens lässtart erbjuds en sådan möjligen i parti D, där ristningens mest glest placerade runor finns (relativt glesare runor är den mest frekventa 
varianten av resursen ifråga och kan därmed innebära ett starkare markerat erbjudande jämfört med tätt placerade runor). Skillnaden i täthet mot parti $\mathrm{A}$ är dock inte stor och resursen kan alltså inte sägas vara tydlig. ${ }^{16}$

Avslutningsvis ska runornas utförande, vilket flera tidigare uttolkare tagit hänsyn till, kommenteras. En anledning till att Nordén $(1937,148)$ läser parti A först är att runorna här är mer jämnt placerade jämfört med övriga partier. Parti B läser han sist eftersom han uppfattar den som ojämnast utförd, både vad gäller storlek och placering av runorna. Även Loman (1965, 53 f.) påpekar något liknande. En eventuell resurs som handlar om runornas utförande har jag som tidigare nämnts inte undersökt i grupp $1 .{ }^{17}$ Framförallt beror det på att jag inte har haft möjlighet att undersöka alla ristade objekt i grupp 1 på plats (runornas utförande är svårt att ta ställning till utifrån fotografier). Vad gäller Skeestenen specifikt stämmer iakttagelsen att parti $\mathrm{B}$ har mer ojämnt placerade runor, dock inte så mycket $\mathrm{i}$ rad $\mathbf{f}$ och inte alls i rad $\mathbf{i}$, men däremot i rad $\mathbf{t}$. Däremot kan jag inte hålla med om att parti A skulle ha påtagligt mer jämnt placerade runor jämfört med parti $\mathrm{C}$ och $\mathrm{D}$ så som Nordén påstår. Snarare upplevs runorna i både parti A och D som lika prydligt placerade jämfört med dem i C.

\section{Kompositionens läsväg}

Resursen partiordning kan erbjuda läsväg i en komposition med flera partier. Resursen innebär att inskriftspartier läses från vänster mot höger eller tvärtom. Stephens tycks inte ha följt detta; hans läsväg mellan partierna (A-C-D-B) hoppar fram och tillbaka (något som inte är belagt i grupp 1). Nordéns läsväg däremot går parti för parti mot vänster (A-DC-B). Denna variant av partiordning är inte lika frekvent som att läsvägen går parti för parti mot höger. Erbjudandet om läsväg mot höger är därmed starkare markerat, och med utgångspunkt i diskussionen ovan om hela kompositionens lässtart respektive B-partiets läsordning ger detta tre alternativ: B(f-i-t)-C-D-A och D-A-B(f-i-t eller i-f-t)-C.

Resursen närliggande startpunkt för parti erbjuder också läsväg eftersom flera av Skeestenens rader löper bustrofedon. En helt oavbruten bustrofedon (och läsväg mot partiet till höger) är emellertid endast möjlig med läsordningen $\mathrm{C}-\mathrm{D}-\mathrm{A}-\mathrm{B}(\mathbf{f}-\mathbf{i}-\mathbf{t})$, och då bara om man bortser från rad $\mathbf{i}$ eller ser den som en del av rad $\mathbf{t}$. En lässtart i parti $\mathrm{C}$ skulle dock

\footnotetext{
${ }^{16}$ Det ska nämnas att resursen placering av parti inte kan markera lässtart på Skeestenen eftersom alla sidor är ristade; det finns alltså inget parti som endast är till vänster eller höger om ett annat.

${ }^{17}$ Att mer ojämnt utformade runor återfinns i kompositioners avslutning kan dock exempelvis ses på DR 143 Gunderup 1 (se fig. 1).
} 
innebära att läsriktningen i kompositionens inledande rad löper uppifrån och ned, vilket är osannolikt då ingen sådan variant av läsriktning $i \mathrm{rad}$ finns i grupp 1. Alla tre föreslagna alternativen ovan, $B(f-i-t)-C-D-A$ ( $\uparrow \downarrow \downarrow \uparrow \uparrow \downarrow)$ och D-A-B(f-i-t eller i-f-t)-C ( $\uparrow \downarrow \uparrow \downarrow \downarrow \downarrow$ eller $\uparrow \downarrow \downarrow \uparrow \downarrow \downarrow)$, innebär dock att bustrofedon avbryts vid något eller några tillfällen. Frågan är om den oavbrutna bustrofedonordningen innebär ett så starkt markerat erbjudande att det är motiverat att räkna med att läsriktningen i kompositionens startrad löper uppifrån och ned. Analysen av grupp 1 ger tyvärr ingen upplysning om i vilken utsträckning man kan räkna med avbrutna bustrofedonordningar eftersom inga sådana läsordningar ingår i gruppen. I de fall en avbruten bustrofedon kan misstänkas (d.v.s. en sådan antas i den allmänt vedertagna läsordningen) går det nämligen inte att bekräfta denna ordning på språklig grund. Tillåter man sig att titta på de allmänt vedertagna läsordningarna ser man i den genomgång Moltke (i $D R$, Text, sp. $822 \mathrm{f}$.) presenterar av det danska materialet att avbrutna bustrofedonordningar förekommer; alternativet $\mathrm{C}-\mathrm{D}-\mathrm{A}-\mathrm{B}(\mathbf{f}-\mathbf{i}-\mathbf{t})$ kan därför troligen avfärdas. Tittar man närmare på Moltkes genomgång ser man att en avbruten bustrofedon förekommer i 11 vikingatida runristningar, av vilka tre är från tidig vikingatid (DR 190 Helnæs, DR 192 Flemløse 1 och DR 209 Glavendrup). På en punkt skiljer sig emellertid Skeestenens läsordningsalternativ med avbrutna bustrofedon från Moltkes exempel; på Skeestenen går läsriktningen i de två raderna mellan vilka bustrofedon avbryts uppifrån och ned, medan de i Moltkes exempel löper nedifrån och upp. Ytterligare en tendens hos Moltkes exempel är att det antingen är i kompositionens inledning eller i dess avslutning som bustrofedonordningen är avbruten. Av alternativen med B eller D som startparti passar detta mönster bäst in på D-A-B(f-i-t)-C ( $\downarrow \downarrow \uparrow \downarrow \downarrow \downarrow)$. Grønvik (1981, 132) tar emellertid upp exempel på ristningar där bustrofedon avbryts för att sedan fortsätta, till exempel enligt mönstret på DR 6 Slesvig: $\uparrow \downarrow \uparrow \uparrow \downarrow$ (ett radupplägg som sträcker sig över tre sidor). ${ }^{18}$ Osäkerheter finns emellertid kring läsordningen på DR 6. Varken alternativet B(f-i-t)-C-D-A ( $\downarrow \downarrow \downarrow \uparrow \downarrow)$ eller D-A-B(i-f-t)-C ( $\uparrow \downarrow \uparrow \uparrow \downarrow \downarrow)$ passar dock riktigt in här. Den förstnämnda gör det inte eftersom tre, inte två, rader i följd löper åt ett och samma håll, den sistnämnda eftersom bustrofedon avbryts vid två tillfällen. Eftersom det är rad i som åstadkommer dessa "avvikelser" kan ordningarna kanske inte helt avfärdas på grund av detta; $\mathbf{i}$-radens plats i läsordningen är osäker. Men ska man välja mellan de två alternativen med lässtart i parti D

${ }^{18}$ Jag återger radriktningen för DR 6 som om stenens första rad löper nedifrån och upp. Stenen ifråga är sannolikt rest åt fel håll (jfr DR, Text, sp. 18, Anm. 1).

Futhark 9-10 (2018-2019) 
är kanske alternativet D-A-B(f-i-t)-C ( $\downarrow \uparrow \uparrow \downarrow \downarrow \downarrow)$ där bustrofedonordningen bara avbryts en gång att föredra framför D-A-B(i-f-t)-C ( $\downarrow \downarrow \uparrow \downarrow \downarrow)$.

Jag räknar som ovan nämnts inte med ett erbjudande om läsordningen $\mathrm{C}-\mathrm{D}-\mathrm{A}-\mathrm{B}(\mathbf{f}-\mathbf{i}-\mathbf{t})$ men alternativet ska ändå kort kommenteras. Ordningen innebär att kompositionens startrad har en läsriktning som löper uppifrån och ned, något som inte förekommer i grupp 1. Det finns dock exempel på detta i det urnordiska materialet, exempelvis på Bo KJ73 Rö vilken liksom Skeestenen är från Bohuslän. Ristningen består av fyra rader vilka samtliga löper uppifrån och ned. Andra ristningar med fler än en rad med läsriktningen uppifrån och ned är N KJ60 Vetteland, U 1125 Krogsta och Vr 1 Järsberg, och med endast en rad till exempel N KJ78 Bø, N KJ92 Eidsvåg, N KJ63 Einang och Vg 65 Norra Vånga kyrka. Även en övergångsinskrift finns med tre rader som löper uppifrån och ned (DR 359 Istaby). I alla dessa exempel löper dock samtliga rader uppifrån och ned, vilket inte är fallet på Skeestenen. En urnordisk ristning med ett radupplägg liknande Skeestenens är emellertid N KJ72 Tune. I ett av Tunestenens två inskriftspartier löper den första radens läsriktning uppifrån och ned medan den andra läses nedifrån och upp. Detta parti har också antagits inleda hela kompositionen. Möjligen skulle man alltså kunna överväga att även Skeestenens komposition inleds av en rad som löper uppifrån och ned, med det får i ljuset av det tidigvikingatida jämförelsematerialet ses som mindre troligt.

Även avstånd till partiets startpunkt ska kommenteras. Resursen uttrycker avgränsning vilket indikerar var läsväg inte går. Den innebär att om två rader ligger kant i kant på var sin sida och har en läsriktning som löper åt samma håll (medan övriga rader inom respektive inskriftsparti löper bustrofedon) ska dessa två rader inte läsas efter varandra. Om man antar att resursen förekommer på Skeestenen kan en läsordning konstrueras som resulterar i en oavbruten bustrofedon (även här krävs dock att man bortser från rad $\mathbf{i}$ alternativt ser den som en del av $\operatorname{rad} \mathbf{t}$ ). De två rader vars läsriktning löper åt samma håll och som alltså inte ska läsas efter varandra är rad $\mathbf{t}$ och raden i parti C. Om man antar att kompositionens lässtart finns i rad $\mathbf{t}$ (eller $\mathbf{i}$ ) och att läsvägen först går mot vänster mot rad $\mathbf{f}$ för att sedan växla riktning och gå mot höger (C-D-A) ger detta en oavbruten bustrofedon B(t/i-f)-C-D-A. Det finns fler läsordningsalternativ där rad $\mathbf{t}$ och raden i parti $C$ inte läses efter varandra, men för att inte behöva räkna med fler än ett "hopp" över rader $\mathrm{i}$ den fortsätta läsningen måste kompositionens lässtart alltid vara i $\operatorname{rad} \mathbf{t} / \mathbf{i}$ alternativt i parti C. Med utgångspunkt i Moltkes (i $D R$, Text, sp. 822 f.) presentation av ristningar där ordningen raderna läses i växlar riktning, ser man att mer än ett "hopp" över rader bara görs i en, DR 62 Sjelle, av 
totalt 16 stycken. Moltke tittar dock bara på läsordningen inom enskilda inskriftspartier, inte inom hela flerparti-kompositioner. Jag utforskar inte vidare alternativ där ordningen partier läses i växlar riktning eftersom det starkast markerade erbjudandet om kompositionens lässtart finns i rad f i parti B eller i parti D (inte i rad t eller parti C).

Slutligen ska jag kort beröra möjligheten att rad i inte ska ses som en del av parti B. Rad i behöver i så fall inte läsas före, efter eller mellan rad $\mathbf{t}$ och $\mathbf{f}$ (d.v.s. möjliga placeringar av i-raden om den räknas till parti B). Istället kan den korta i-raden eventuellt ses som en fortsättning på någon av de andra raderna, närmast till hands ligger den i parti D. D-partiets rad löper nämligen nedifrån och upp och fortsätter man över toppen (där visserligen ingen ristning finns) kan eventuellt i-raden, som löper uppifrån och ned, utgöra fortsättningen, framförallt erbjudet genom närliggande startpunkt för rad. I grupp 1 skulle DR 2 Haddeby 2 och DR 4 Haddeby 4, vilka båda har rader som löper från en sida över toppen och ned på en annan, vara jämförbara. Ordningen D-i kan också jämföras med upplägget på Sigtunablecket 1 (U Fv1933;134) där bleckets baksida inte hade rum för de avslutande runorna utan de återfinns istället inträngda i en av framsidans rader (Pereswetoff-Morath 2019, 88). Att D-i på ett likande sätt skulle utgöra kompositionens avslutning är dock inte möjligt utifrån något av de ovanstående förslagen eftersom dessa aldrig placerar parti $\mathrm{D}$ sist. Ett annat alternativ är att i-raden helt enkelt läses som avslutning på raden i parti $\mathrm{D}$ och att läsvägen sedan fortsätter mot vänster från parti $\mathrm{D}$ sett, det vill säga till parti A. Eftersom de ovan föreslagna läsvägarna har ordningen D-A kan alternativet D-i-A enkelt passas in, exempelvis D-i-A$\mathrm{B}(\mathbf{f}-\mathbf{t})-\mathrm{C}$ respektive $\mathrm{B}(\mathbf{f}-\mathbf{t})-\mathrm{C}-\mathrm{D}-\mathbf{i}-\mathrm{A}$. Mot en läsordning $\mathrm{D}-\mathbf{i}-\mathrm{A}$ talar att den avfasade ytan som rymmer rad $\mathbf{i}$ är tydligt vinklad mot B-partiet, inte mot A, vilket gör i och B visuellt knutna till varandra. För en läsordning D-i-A talar däremot att radslut för i-raden befinner sig i samma höjd som början på raden i parti $\mathrm{A}$, samt att dessa båda rader löper i samma riktning, vilket alltså snarare gör i och A visuellt förbundna (upplägget påminner om resursen närliggande startpunkt för rad).

\section{Sammanfattning}

Flera möjliga läsordningar kan övervägas för Skeestenens komposition. Läsväg i parti B är troligen $\mathbf{f}$-i-t, eller möjligen i-f-t om A-partiet läses före $\mathrm{rad} \mathbf{i}$. Ett erbjudande om lässtart för kompositionen finns $i \operatorname{rad} \mathbf{f} i$ parti B och i parti D. Det starkast markerade erbjudandet om lässtart och

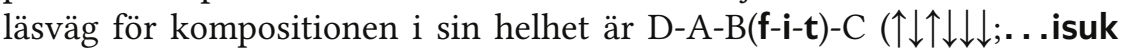
fulk. . . . . . ftinua ip tinufoip̣̣. . . kilfiar . . .) varför parti D alltså troligen 
utgör kompositionens start. Ska kompositionsstart övervägas i B finns ett möjligt erbjudande om läsordningen B(f-i-t)-C-D-A $(\uparrow \downarrow \downarrow \downarrow \uparrow \downarrow ; \ldots$ ftinua ip tinufoipu. ... kilfiar... . . . isuk fulk...). Om i-raden inte betraktas som en del av parti B finns ett erbjudande om läsväg D-i-A (. . . isuk ip fulk. .. ). De två erbjudanden ovan har därmed en alternativ väg $D-\mathbf{i}-\mathrm{A}-\mathrm{B}(\mathbf{f}-\mathbf{t})-\mathrm{C}$ respektive $\mathrm{B}(\mathbf{f}-\mathbf{t})-\mathrm{C}-\mathrm{D}-\mathbf{i}-\mathrm{A}$.

\section{U ANF1937;163 Björkö}

Silverhänget, U ANF1937;163 Björkö, består av fyra rader (se fig. 11). Själva hänget har två delar, en konvex dekorerad ovansida och en baksida eller botten där runristningen finns. Föremålet är litet, cirka 1,6 cm brett och 1,7 cm långt (Imer 2007, "Katalog", 20). De största runorna är $4 \mathrm{~mm}$ och i övrigt oftast $3 \mathrm{~mm}$ (Nordén 1937, 161). ${ }^{19}$ Runinskriften är så vitt jag kan se ristad efter det att hålen gjorts. Men Nordén (s. 164) menar tvärtom att ett av hålen nästan utplånat en runa i rad A. Lisbeth Imer (2007, "Katalog", 20) har dock inte läst någon runa här. Hur objektet använts kan ha betydelse för erbjudandet om läsordning. Om föremålet exempelvis har burits kan det ha givit raderna en orientering i rummet. Det dock svårt att bestämma vilken. Nordén (1937, 160 f., 168) anser istället att föremålet ska ha varit fastnitat vid ett underlag (bälte, dolkfäste eller liknande). I så fall skulle ristningen ha varit dold. Wladyslaw Duczko $(1985,66)$ menar däremot att öppningen i hängets överdel är sekundär vilket visar att föremålet gjorts om till en form av luktkapsel, anpassad för att innehålla någon typ av doftande vegetabilier.

Raderna nedan är uppställda utifrån hur de är arrangerade på objektet (d.v.s. från höger mot vänster enligt fig. 11). Läsningen är hämtad från Imer 2007, "Katalog", 20:

1. sak arf hitṛk

2. pat ik uk m nona

3. snonkukțịunfị

4. pik

\section{Tidigare forskning}

Två tidigare läsordningsförslag finns, Nordéns (1937; 1940) och Imers (2007, "Katalog”). Hur Nordén $(1937,161,164)$ bestämt sin läsordning är inte helt genomskinligt. I vissa avseenden följer hans resonemang det

${ }^{19}$ Jag har p.g.a. tidsbrist tyvärr inte haft möjlighet att se objektet själv. 
visuella erbjudandet; Nordén delar ristningen i två delar, rad 2-1 och rad $3-4$, vars respektive rader ligger i anslutning till varandra visuellt. Han framhåller också att raderna ifråga har ett visuellt samband med varandra eftersom de löper bustrofedon (resurserna närhet mellan rader och närliggande startpunkt för rad följs alltså). Samtidigt tycks utgångspunkten för att gruppera raderna just i dessa par och i den angivna ordningen vara språkligt grundad; de två radparen utgör nämligen enligt Nordén var sitt satssammanhang. Han vill däremot inte bestämma en ordning mellan de båda radparen med utgångspunkt i språket. I ett annat sammanhang redovisar han $(1940,323)$ emellertid ordningen 3-4-2-1. Staffan Nyström (1992, 67), Birkmann (1995, 259-261; båda med invändningar) och Ingrid Sanness Johnsen (1968, 127 f.) upprepar Nordéns läsordning. Imer (2007, "Katalog", 20) presenterar istället ett nytt förslag (2-3-1-4), men utan att motivera detta. Utifrån den uppsättning resurser jag urskilt kan placering av rad och radordning (d.v.s. varianten med lässtart i en mittrad och där läsordningen mellan raderna växlar riktning) sägas erbjuda Imers ordning. Dock växlar riktningen i Imers förslag vid två tillfällen, något som inte finns belagt i grupp 1 och är osannolikt mot bakgrund av Moltkes genomgång (i $D R$, Text, sp. 822 f., se ovan). Möjligen har Imer också följt resursen runstorlek då hon valt lässtart. Eftersom hon lämnar inskriften otolkad har dock knappast en språklig tolkning styrt.

Kompositionens lässtart och läsväg

Då läsordning på U ANF1937;163 Björkö diskuteras använder jag de resurser som urskilts ovan, trots att de i huvudsak är belagda på resta stenar. Som tidigare nämnts finns inga indikationer på att andra resurser förekommer i ristningar på lösföremål jämfört med dem på sten (förutom att objektets orientering i rummet inte är given för lösföremål i samma utsträckning). För att kunna diskutera de resurser som förutsätter att radernas riktning kan fastställas antar jag att resursen läsriktning $i$ rad kan tillskrivas Björköhängets komposition; radernas riktning bestäms alltså genom att hänget vrids så att startraden alltid ligger vertikalt med en läsriktning nedifrån och upp.

Varken Nordéns eller Imers förslag följer helt den visuella kompositionens erbjudande om läsordning. Utifrån ovan urskilda resurser menar jag att två olika läsordningar är möjliga. Den första har ordningen 1-2-3-4. Resursen radläng $d$ kan indikera lässtart i en längre kantrad och avslutning i den kortare, vilket här innebär start i rad 1 och avslut i rad 4. Dock erbjuds inte lässtart i rad 1 i dess egenskap av kompositionens längsta rad; rad 2 och 3 är något längre. Resursen närliggande startpunkt för rad kan också 
peka på läsordningen 1-2-3-4 eftersom raderna då löper bustrofedon. Om hänget vrids så att startrad $1 \mathrm{i}$ enlighet med resursen läsriktning $i$ rad löper nedifrån och upp, går läsordningen 1-2-3-4 från raden längst till höger och sedan mot vänster. Denna utformning av resurserna placering av rad och radordning finns i grupp 1 men är mindre frekvent jämfört med det omvända (från vänster mot höger).

Den andra läsordningen som erbjuds visuellt i texten är 2-1-3-4. Den mest frekventa varianten av resursen runstorlek visar på lässtart i rad 2 då denna inleds med något större runor än de övriga raderna, som är ungefär lika stora. Även den mest frekventa varianten av radlängd kan erbjuda lässtart i 2 (eller 3); dessa är något längre än rad 1. Slutligen kan runtäthet möjligen erbjuda lässtart i rad 2; inledningsvis är runorna placerade något glesare än i övriga rader, vilket får den att avvika visuellt (glesare runor är också den något mer frekventa varianten av resursen ifråga). Om lässtart finns i mittraden 2 förutsätts en läsväg där ordningen raderna läses i växlar riktning. Istället för den ordning som Imer presenterar - en typ som inte finns representerad i grupp 1 - föreslår jag den variant av resurserna placering av rad och radordning där läsväg först går mot raden till vänster (1) och därefter fortsättning mot höger (3-4), alltså 2-1-3-4 (d.v.s. samma två enheter som Nordén identifierar, 2-1 respektive 3-4, men i omvänd ordning). Även i detta fall avslutar alltså den korta kantraden. Resursen närliggande startpunkt för rad kan i viss utsträckning sägas peka på ordningen 2-1-3-4 $\uparrow \downarrow \downarrow \uparrow ;$ rad 2-1 respektive 3-4 löper bustrofedon, dock inte raderna 1 och 3 . Att en läsväg med växlande riktning kombineras med att bustrofedon avbryts finns ett exempel på i grupp 1, nämligen i parti $\mathrm{A}$ på DR 209 Glavendrup (se fig. 2). Enligt Moltkes (i DR, Text, sp. 821-823) presentation finns möjligen även exempel i det senvikingatida materialet (DR 37 Egtved och DR 150 Hurup). På grund av skador är emellertid dessa läsordningar knappast säkra. Ett ytterligare exempel (Öl 1 Karlevi) finns i Grønviks $(1981,132)$ genomgång av bustrofedonordningar. I ingen av dessa ristningar löper emellertid de två raderna som avbryter bustrofedon uppifrån och ned som på silverhänget, utan nedifrån och upp, och bara på Öl 1 avbryts bustrofedon för att sedan återupptas.

Avslutningsvis finns ett ungefär lika starkt markerat erbjudande om lässtart i rad 1 som i rad 2; både radlängd respektive runstorlek (varianten med lässtart i den längre kantraden respektive raden med större runor) är frekventa. Vad gäller läsväg finns utifrån frekvensen hos resurserna placering av rad och radordning ett något starkare erbjudande om lässtart i högra raden och en läsväg mot vänster jämfört med lässtart i en mittrad och en växlande riktning för ordningen raderna läses i. Den sistnämnda 
varianten finns heller inte representerad bland lösföremål eller på svensk mark, och uppträder på Björköhänget i så fall i en ovanlig variant eftersom den kombineras med en avbruten och återupptagen bustrofedonordning. Sammantaget är därför erbjudandet om läsordningen 1-2-3-4 något starkare markerat jämfört med 2-1-3-4.

Sammanfattning

På Björköhänget finns ett något starkare markerat erbjudande om läsordningen 1-2-3-4 (sak ârf hitṛk pat ik uk ṃ nona snonkukț̣unfị pik), jämfört med 2-1-3-4 (pat ik uk ṃ nona sak arf hitṛk snonkukț̣unfị pik) vilken också är möjligt.

\section{DR NOR1988;5 Malt}

DR NOR1988;5 Malt utgörs av en $220 \mathrm{~cm}$ hög och $85 \mathrm{~cm}$ bred sten (Stoklund 1989, 4). Kompositionen består av två vertikala rader med en läsriktning som löper nedifrån och upp, samt sex horisontala rader som läses från vänster mot höger (se fig. 12). Den nedersta horisontala raden är dock uppochnedvänd och löper bustrofedon med den föregående. I den ordning som presenteras i Samnordisk runtextdatabas läses de vertikala raderna först från vänster mot höger och därefter de horisontala uppifrån och ned. Läsningen följer Stoklund 1994, 190 f.:

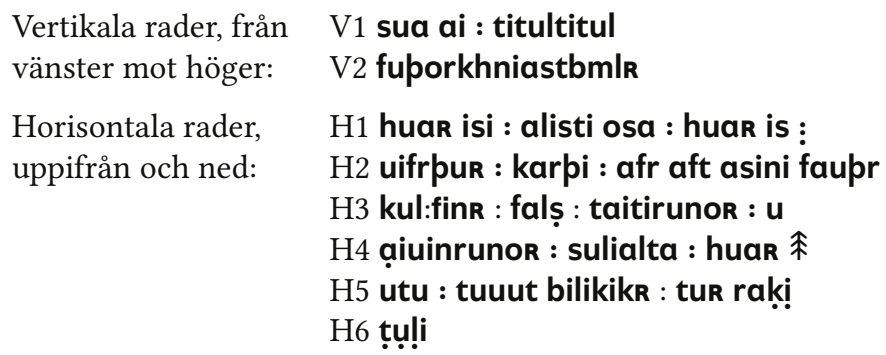

Tidigare forskning

För DR NOR1988;5 Malt finns flera föreslagna läsordningar. Till ordningen V1-2, H1-H6 ansluter sig Marie Stoklund (1989, 5; dock endast genom en translitterering där läsordningen inte kommenteras), Grønvik (1991, 188 f.; 1992, 2-4) och Kees Samplonius (1992, 65-68; som dock öppnar för andra alternativ). Den omvända ordningen, H1-H6, V1-2 förespråkas av Kurt Braunmüller (1991, 121; 1992, 150 f.) och Lars Heltoft (2017, 29), den sistnämnde genom en translitterering utan kommentar av läsordningen. 
Birkmann (1995, 361-372) presenterar och utvärderar tidigare tolkningsförslag, men ger ingen egen helhetstolkning. Läsordningen verkar han heller inte vilja ta ställning till utan translittererar ordningen V1-2, H1-H6 (så också i Birkmann 1994, 203) men kommenterar tolkningen i ordningen $\mathrm{H} 1-\mathrm{H} 6, \mathrm{~V} 1-2$. Det är något oklart vilka läsordningar Karen Thuesen (1990) respektive Stoklund (1994) förespråkar.

Även om den inbördes ordningen mellan de vertikala respektive horisontala radgrupperna växlar verkar alltså de flesta uttolkare vara överens om att de vertikala raderna ska läsas från vänster mot höger och de horisontala uppifrån och ned, vilket är i enlighet med den mest frekventa varianten av resursen placering av rad och radordning.

Grønvik (1991, 188; 1992, 3) menar att de vertikala raderna ska föregå de horisontala eftersom H6 bör utgöra hela kompositionens avslutning då gott om plats för en eventuell fortsättning finns efter denna korta rad. Resonemanget anknyter till resursen radlängd (läsväg), det vill säga ristningens avslut finns i den kortare av de två kantraderna (i detta fall dock i horisontellt lagda rader istället för vertikalt). Samplonius (1992, 65-68) redovisar samma ordning som Grønvik, men menar samtidigt att ordningsföljden mellan de vertikala och horisontala raderna inte kan bestämmas säkert. Han resonerar kring olika alternativ med utgångspunkt i ristarens arbetsprocess. Han menar exempelvis att de horisontala raderna ristades först eftersom de vertikala har anpassats efter dessa, och diskuterar också Stoklunds (1994) förslag att de tomma vertikala raderna ska förstås som inskriftens slut. Det verkar alltså som att han föredrar att läsa de horisontala raderna först. Men eftersom rad H6 är kort och löper bustrofedon med rad H5 tänker sig Samplonius att ristaren ville markera samhörigheten mellan H6 och de övriga horisontala raderna (Samplonius följer alltså närliggande startpunkt för rad), annars hade ristaren lika gärna kunnat placera $\mathrm{H} 6$ bland de vertikalt lagda raderna, alternativt ristat runföljderna i de vertikala raderna direkt efter H6. Samplonius slutsats är att innehållet i de vertikala raderna inte är en direkt fortsättning på det i de horisontala, vilket innebär att även läsordningen V1-V2, H1-H6 är möjlig.

Braunmüller (1992, 150 f.) menar istället att de horisontala raderna ska läsas före de vertikala. Han bygger i första hand på antaganden om ristaren arbetsgång (och utgår då från ristningsytans förutsättningar samt ristarens förkunskaper) som han likställer med ristningens läsordning. En spricka löper horisontellt mitt över stenen och denna ska ha tvingat ristaren att placera den första raden horisontellt längsmed sprickan, istället för vertikalt över denna. Efter att de övriga horisontala raderna ristats används ytan över sprickan till vertikala rader, i enlighet med hur 
rader normalt placeras $\mathrm{i}$ vikingatida ristningar på sten samt estetiska överväganden, menar Braunmüller. Själva separeringen i två grupper av rader tänker han sig motsvarar en innehållslig uppdelning.

Vilken läsordning Thuesen (1990) förespråkar är inte helt klart. Hon redovisar (s. 45 f.) ordningen H1-H6, V1-V2 i en sammanfattande translitterering och då hon uttryckligen kommenterar (s. 18) läsordningen uppger hon att raderna bör läsas enligt det mest frekventa mönstret: "'ovenfra' og ned og fra venstre mod højre". Här är det alltså placering av rad och radordning som aktualiseras. Thuesen (s. 18-37) frångår dock delvis denna princip då hon presenterar sin tolkning. Här börjar hon med "mindeindskriften" (H2-H3-H4 fram t.o.m. runa 10), därefter "gåden" (H1H4 fr.o.m. runa 11 fram t.o.m. runa 22), "besværgelsen" (H4 runa 23, H5H6) och till sist "værneformlerne" (V1-V2). Då hon inleder sin tolkningspresentation med "mindesinskriften" motiverar hon detta med att denna del av inskriften är mest lättillgänglig och liknar andra i störst utsträckning. Vad gäller hoppet från $\mathrm{H} 1$ till mitten på rad $\mathrm{H} 4 \mathrm{i}$ "gåden" menar hon att det framgår att svaret på gåtan i rad $\mathrm{H} 1$ finns i H4 eftersom runföljden huar upprepas där. Jag är osäker på om Thuesen verkligen förespråkar en läsordning med start i H2 samt hopp fram och tillbaka mellan rader, eller om hon väljer att presentera inskriften på detta sätt för att göra det innehållsliga sammanhanget klarare. Om det förstnämnda är riktigt liknar läsordningen närmast den infrekventa varianten av placering $a v$ rad och radordning (d.v.s. lässtart i en mittrad och en växlande riktning för den ordning raderna läses i). Dock finns inget liknande exempel på en så komplicerad läsväg med hopp fram och tillbaka mitt i inskriftsrader. Närmast kommer kanske DR 4 Haddeby 4 där lässtart för rad 1 finns en bit upp mellan två ramlinjer som inledningsvis rymmer rad 3. Runföljderna i rad 1 och 3 har dock olika läsriktning, vilket inte någon av Maltinskriftens rader har.

Stoklund (1994) uttrycker sig vagt vad gäller både helhetstolkning och läsordning. Hon presenterar (s. 182 f.) en translitterering i ordningen V1V2, H1-H6 och kallar de vertikala raderna A1-A2 och de horisontala B1B6 men skriver (s. 182) samtidigt att detta är "[u]den hensyn til eventuel rækkefølge". Om läsordningen uppger hon (s. 190) att de tomma raderna eventuellt kan förstås som att inskriften slutar här, och i så fall ska de vertikala raderna läsas sist. De horisontala raderna menar hon förmodligen ska läsas uppifrån och ned men påpekar samtidigt att detta inte är givet och nämner Oklundahällen (Ög N288; se fig. 8), vars rader kan läsas nedifrån och upp, som en möjlig parallell. Stoklund överväger också en växlande riktning för ordningen de horisontala raderna läses i, närmare 
bestämt H3-H6, H1-H2. Hon motiverar detta med att H2, som här blir den avslutande raden, är längre än de övriga (H2 sträcker sig runt sidans kant). Detta kan tyda på att rad H2 ristats sist, menar hon. Stoklund följer alltså den mest frekventa varianten av placering av rad och radordning, men berör också de mer infrekventa varianterna.

\section{Kompositionens lässtart och läsväg}

Om man utgår från resursen olika radriktning ska de horisontala raderna läses för sig och de vertikala för sig. Enligt resursen större grupp av rader finns lässtart bland de rader som är lagda horisontellt, eftersom dessa tillsammans tar upp en större yta än de vertikala. Men om man istället tar fasta på resursen närhet mellan rader bör kanske snarare de vertikala raderna läsas före de horisontala (om man antar att de horisontala raderna läses i ordningen $\mathrm{H} 1-\mathrm{H} 6$ ); avståndet är närmre mellan de vertikala raderna och $\mathrm{H} 1$ jämfört med mellan $\mathrm{H} 6$ och de vertikala raderna. Olika radriktning och större grupp av rader är mycket infrekventa resurser i grupp 1 (den förstnämnda finns endast ett belägg på) medan närhet mellan rader är mycket frekvent. Trots detta bedömer jag att de två förstnämnda resurserna resulterar i ett starkare markerat erbjudande om läsordning eftersom de på Maltstenen är visuellt mycket tydliga.

Ett visuellt drag som inte tolkats som en resurs (eftersom inga belägg finns på detta fenomen i grupp 1) är tomma rader. Så som Stoklund (1994, 190) föreslår tyder dessa möjligen på att inskriftens slut finns i de vertikala raderna. En annan möjlighet är att de tomma raderna endast visar att slutet på det avsnitt som avsågs för de vertikala raderna finns där. Går man till det urnordiska materialet finns ett exempel, Vg 63 Noleby, där tomma rader verkar följa på inskriftens avslutning. Ordningen mellan Nolebystenens tre rader går dock inte att fastställa på språklig grund eftersom den mittersta raden är otolkad. Dock består den nedersta raden (om raderna ses horisontellt) som föregår de tomma raderna av en mycket kort runföljd, vilket brukar vara ett visuellt drag kopplat till ristningens avslutning. Om de tomma raderna på Maltstenen ska förstås som avslutning bör, som Samplonius $(1992,65)$ påpekar, läsvägen snarast gå från höger mot vänster, alltså V2-V1.

\section{Lässtart och läsväg $i$ de vertikala raderna}

I de vertikala raderna tycks ett något starkare markerat erbjudande om lässtart finnas i rad V2 (vilket följaktligen ger läsvägen V2-V1), framförallt genom den mer frekventa varianten av radlängd: V2 är $55 \mathrm{~cm}$ medan V1 bara är $44 \mathrm{~cm}$ (de tomma raderna till vänster om V1 är ännu kortare). 
(Alla mått i det följande baseras på egen mätning.) Vidare indikerar den mer frekventa varianten av runtäthet (lässtart i den rad med inledningsvis relativt glest placerade runor) också lässtart i V2. Vad gäller runstorlek är denna resurs otydlig i de vertikala raderna. Inledningsvis är runorna i både rad V1 och V2 cirka $10 \mathrm{~cm}$, men mot slutet av rad V1 är de cirka $11 \mathrm{~cm}$, medan runorna på motsvarande höjd i rad V2 är cirka $9 \mathrm{~cm}$. Vad gäller placering av rad är den mest frekventa varianten lässtart i raden längst till vänster. Eftersom frekventa varianter av radlängd och runtäthet tycks peka på lässtart i rad V2 är det emellertid mer sannolikt att det är den mer infrekventa variant av placering av rad, lässtart i raden längst till höger, som är aktuell i detta fall, i synnerhet om hänsyn också tas till att de tomma raderna kan indikera ordningen V2-V1.

\section{Lässtart $i$ de horisontala raderna}

I de horisontala raderna erbjuds lässtart i rad $\mathrm{H} 1$ respektive H2. Lässtart i H2 erbjuds genom den mycket infrekventa varianten av runstorlek (lässtart finns i raden med mindre runor); alla horisontella rader har nämligen ungefär lika stora runor (c:a 9-11 cm inledningsvis), utom $\mathrm{H} 2$ vars runor upplevs något mindre i jämförelse $(8,5-9 \mathrm{~cm}$ inledningsvis) och på så sätt avviker visuellt från de övriga raderna. Resursen är dock otydlig. Även den mer frekventa varianten av radlängd (lässtart i den längsta raden) tycks erbjuda lässtart i H2. Rad H2 är $85 \mathrm{~cm}$ medan $\mathrm{H} 4$ är $73 \mathrm{~cm}$ och H3 $70 \mathrm{~cm}$. Övriga rader är ännu kortare. Dock upplevs inte H2 som en längre rad om stenen betraktas framifrån; raden fortsätter runt kanten till stenens kortsida, men detta är svårt att se. Om ristningen en gång varit uppmålad kan man dock tänka sig att radlängden framgick tydligare visuellt. Radlängd kan även erbjuda lässtart i H1; då det är en skillnad i längd mellan två kantrader finns ett erbjudande om lässtart i den längre av dem (H1), oavsett längden på raderna däremellan.

När det kommer till resursen placering av rad (och även radordning) tycks, som beskrivits ovan, lässtart och läsväg för horisontalt lagda rader följa samma principer som läsordningen i vertikala rader med den skillnaden att de horisontala raderna är vridna ett kvarts varv. Det finns därmed ett starkt markerat erbjudande om lässtart i H1 eftersom startraden enligt den mest frekventa varianten av placering av rad finns i den översta raden (raden längst till vänster i ett vertikalt upplägg). Enligt en mer infrekvent variant av resursen ifråga erbjuds lässtart i en av raderna $i$ mitten. Närmast till hands ligger att i så fall starta i H2 eftersom flera andra resurser som ovan nämnts pekar åt det hållet. Lässtart i rad H1 erbjuds också genom resursen radläge. $\mathrm{H} 1$ avviker visuellt från majoriteten av de 
övriga raderna genom att börja lite längre in (högre upp om raderna ses vertikalt). Bara $\mathrm{H} 5$ startar i samma läge (i princip kan resursen alltså sägas erbjuda lässtart även i H5).

Det är inte självklart var det starkast markerade erbjudandet om lässtart finns i de horisontella raderna. Flera något otydliga (och vissa väldigt infrekventa) resurser tycks erbjuda lässtart i $\mathrm{H} 2$, medan lässtart i H1 framförallt erbjuds genom en väldigt frekvent variant av resursen placering av rad.

\section{Läsväg $i$ de horisontala raderna}

Resursen radlängd kan indikera läsväg på så sätt att kompositionens inledning finns i den längre kantraden och dess avslutning i den kortare. Omsatt till de horisontala raderna på Maltstenen finns här ett erbjudande om läsväg uppifrån och ned, med start $\mathrm{i}$ den längre $\mathrm{H} 1$ och avslut $\mathrm{i}$ den betydligt kortare H6. Även radavgränsning pekar åt samma håll; H1 är avgränsad genom ramlinjer (den ena bestående av sprickan som löper tvärs över stenen) medan H6, så vitt det går att avgöra på grund av skadorna, inte avgränsas med hjälp av en ramlinje utefter runornas toppar. Vidare visar närliggande startpunkt för rad att raderna $\mathrm{H} 5-\mathrm{H} 6$, som löper bustrofedon, ska läsas efter varandra.

Radordning kan erbjuda två alternativa läsvägar beroende på om lässtart är i H1 eller i H2. Med lässtart i H1 erbjuds läsväg i enlighet med den absolut mest frekventa varianten av resursen uppifrån och ned (eller från vänster mot höger i ett vertikalt upplägg). Stoklund $(1994,190)$ nämner alternativet nedifrån och upp, alltså H6-H1. Eftersom H6 är betydligt kortare än övriga rader samt löper bustrofedon med $\mathrm{H} 5$ är denna läsväg inte trolig. Om lässtart istället finns i H2 erbjuder resursen radordning en läsväg med en växlande riktning för den ordning raderna läses i. Om endast ett "hopp" ska göras mellan rader som inte ligger bredvid varandra (se avsnittet om Skeestenen ovan) och avslutningen ska finnas i H6 är endast läsvägen H2H1-H3-H4-H5-H6 möjlig. Stoklunds $(1994,190)$ alternativ H3-H4-H5-H6H1-H2 är mindre sannolikt eftersom ett så starkt markerat erbjudande om avslut finns i H6. För Stoklunds argument att den längsta raden bör förstås som den avslutande har jag inga paralleller i grupp 1. Tvärtom är den längsta raden som ovan nämnts kopplad till lässtart.

\section{Sammanfattning}

På Maltstenen finns ett starkare markerat erbjudande att läsa de horisontala raderna före de vertikala, och de vertikala raderna i ordningen V2-V1. Två erbjudanden om läsordningen finns för de horisontala raderna: $\mathrm{H} 1-\mathrm{H} 6$ 
samt H2-H1-H3-H4-H5-H6. Möjligen är det förstnämnda något starkare markerat.

\section{Sammanfattning och diskussion}

Med utgångspunkt i socialsemiotisk teori och en multimodal syn på text har jag undersökt tidigvikingatida runtexter med avseende på vilka visuella resurser som erbjuder en läsordning. Det teoretiska ramverket innebär en annorlunda infallsvinkel på ett material som tidigare studerats med tyngdpunkt på den språkliga tolkningen. Perspektivet motiveras av att även om det språkliga innehållet givetvis styr val av läsordning är det visuella intrycket alltid det som först möter en betraktare. Att uppmärksamma denna dimension är därför en viktig forskningsuppgift. Studiens första syfte är därmed att identifiera (eventuella) gemensamma principer för textens visuella erbjudande om läsordning(ar) i det nordiska runmaterialet från tidig vikingatid. En analysmodell för att undersöka detta har därför konstruerats: I de kompositioner vars läsordning kan bestämmas utifrån språkliga kriterier (grupp 1) har de visuella drag som pekar på denna språkligt grundade läsordning identifierats (övriga ristningar har förts till grupp 2). Närmare bestämt har jag på språklig grund identifierat lässtart i tre visuella element ( $r a d$, parti och komposition) samt läsväg mellan två element (mellan rader och mellan partier). Av de visuella drag som indikerar den språkligt givna läsordningen har de mest framträdande eller frekventa identifierats som gemensamma principer för visuella erbjudanden om läsordning och därmed tolkats som visuella resurser. Med utgångspunkt i Kress och van Leeuwens (2006) modell för bildens grammatik antas de visuella resurserna kunna uttrycka betydelser som framskjutenhet, sambandskapande eller avgränsning och på så sätt vara knutna till läsordningsfunktioner som lässtart eller läsväg. Vissa resurser tycks inte uttrycka någon av dessa betydelser och jag antar då istället en direkt koppling genom konvention till läsordningsfunktioner. En gradering görs av huruvida resurserna resulterar i ett starkt eller svagt markerat erbjudande om läsordning. Starka erbjudanden är ett resultat av resurser som är frekventa i materialet i stort eller extra framträdande i en viss komposition.

Där tidigare forskning främst intresserat sig för avsändarens (d.v.s. ristarens) ordning har jag - utifrån en textsyn som utgår från Eco 1981 istället undersökt textens erbjudande om läsordning. Valet motiveras av att vi idag vet lite om ristarens arbetsprocess och samtida läsarbeteenden. Det som finns kvar att studera är själva texten. Genom att tala om textens 
erbjudande om läsordning utgår jag alltså i första hand från det material som vi idag kan säga något om.

Den analysmodell jag presenterar för att urskilja visuella resurser är ett steg mot att skapa en gemensam utgångspunkt för hur man kan tänka kring utforskandet av läsordning i runmaterialet. Modellen innebär en systematisk undersökning av visuella läsordningsprinciper grundad på hur det samlade tidigvikingatida runmaterialet faktiskt ser ut. Tidigare har det i stor utsträckning varit upp till den enskilda forskaren att avgöra vilka faktorer som är relevanta. För att undvika att sådana beslut blir godtyckliga eller anpassas till den språkliga tolkning som förespråkas behövs en diskussion kring metod och teoretiska utgångspunkter.

Utifrån den föreslagna analysmodellen har gemensamma principer för textens visuella erbjudande om läsordning undersökts. Ett antal visuella resurser som kan antas vara kopplade till läsordning har urskilts. Några resurser har potential att uttrycka framskjutenhet genom att visuellt avvika från de övriga delarna av kompositionen och detta kan markera lässtart visuellt. Det handlar om runstorlek, radlängd, radläge, runtäthet, närvaro eller frånvaro av skiljetecken, radavgränsning samt större grupp av rader och större parti. Då ett element i kompositionen är framskjutet finns där också något som är mindre framskjutet. Därmed säger resurserna ifråga också något om läsväg (det mer framskjutna elementet läses före det mindre framskjutna). Resurser med potential att uttrycka sambandskapande visar var läsvägen går. På ett allmänt plan handlar det om närhet mellan rader, men också mer specifikt om närliggande startpunkt för rad och närliggande startpunkt för parti. Omvänt visar resurser med potential att uttrycka avgränsning var läsväg inte går (avstånd mellan rader, avstånd till radens startpunkt och avstånd till partiets startpunkt). Avgränsning kan också realiseras genom olika radriktning. Slutligen finns resurser som jag antar är direkt kopplade till läsordningsfunktioner genom konvention. Av dessa kan läsriktning $i \mathrm{rad}$, placering av rad till höger, vänster eller $\mathrm{i}$ mitten, samt placering av parti till höger eller vänster kopplas till lässtart, medan radordning och partiordning (d.v.s. raderna respektive partierna läses mot höger, vänster eller [för raderna] med växlande riktning) kan säga något om läsväg.

Den visuella analysen av grupp 1 har utgått från bestämda samband mellan betydelsesystem och läsordningsfunktioner som formulerats enligt Kress och van Leeuwens (2006) analysmodell (framskjutenhet kopplas till lässtart, sambandskapande till läsväg och avgränsning till var läsväg inte går). I de allra flesta fall tycks undersökningsmaterialet bekräfta dessa samband, men några exempel finns där modellen inte verkar fungera lika väl. 
I första hand gäller det sambandet mellan sambandskapande respektive avgränsning och läsväg. Då underlaget undersöktes för att tolka närhet mellan partier i en komposition som en resurs, visade det sig finnas fler exempel på att läsväg går mellan partier som avgränsas från varandra visuellt jämfört med mellan partier som befinner sig nära varandra. ${ }^{20}$ Ingen resurs urskildes därför eftersom det visuella uttrycket alltså går på tvären med de samband mellan betydelse och funktion som jag utgår från. Ytterligare ett exempel är kompositioner vars rader på språklig grund läses efter varandra samtidigt som de separeras visuellt av andra rader (här urskiljs emellertid en resurs närhet mellan rader som innebär att rader vilka placeras intill varandra också läses efter varandra, eftersom beläggen på detta är så många fler). Frågan är om dessa två exempel innebär att Kress och van Leuuwens modell inte stämmer eller om det finns en annan förklaring. Vad gäller de visuellt separerade raderna finns dessa i kompositioner med lässtart i en vertikal mittrad och läsväg först mot raden/raderna till vänster, sedan mot höger genom ett hopp till raden höger om mittraden. En möjlighet är att ett radupplägg som på detta sätt bryter mot den mycket frekventa resursen närhet mellan rader i första hand uttrycker andra typer av betydelser än sådana som kan knytas till läsordning. Närmast till hands ligger att radupplägget ifråga framhäver resaren av monumentet som viktig; framskjutenhet uttrycks genom att startraden, som inleds med resarens namn, befinner sig i inskriftspartiets mitt. Någon lika uppenbar förklaring till upplägg där partier som befinner sig på ett visuellt avstånd från varandra ändå ska läsas efter varandra har jag inte hittat. För DR 209 Glavendrup och DR 230 Tryggevælde kan det möjligen handla om att objektets sidor fungerar som avgränsare av olika innehållsligt skilda delar. Att vissa av dessa delar är längre än andra kan ha varit styrande för vilken yta av stenen de placerats på vilket alltså kan vara anledningen till att exempelvis den avslutande korta förbannelseformeln på DR 209 placerats på kortsidan och på så sätt befinner sig mellan de två bredsidorna som enligt den språkligt givna ordningen ska läsas efter varandra (se fig. 2). Dessa exempel visar alltså kanske snarare att de visuella uttrycken inte alltid primärt har med läsordningsfunktioner att göra. Även om de uppställda sambanden mellan betydelse och läsordningsfunktion inte alltid gäller måste därför kanske inte Kress och van Leeuwens modell i sig modifieras.

Att undersöka de gemensamma principerna för textens visuella erbjudande om läsordning handlar också om att beskriva en aspekt av den

\footnotetext{
${ }^{20}$ Endast kompositioner med minst tre partier granskades här. För att säga att två partier ligger nära varandra krävs ett tredje parti som befinner sig längre bort.
} 
tidigvikingatida skriftkulturen. Frågan är hur de urskilda resurserna ska tolkas. I det följande görs en koppling mellan graderingen av resurserna i ett starkt respektive svagt markerat erbjudande och tidigvikingatida textkonventioner. Även om graderingen inte är primärt utformad för att beskriva skriftkulturen är en naturlig utgångspunkt för ett resonemang kring textkonventioner just iakttagelser om resursernas frekvens och hur de faktiskt ser ut i enskilda kompositioner.

Ser man på frekvens tycks resursen läsriktning $i$ rad (kompositionens startrad löper nedifrån och upp) förekomma i princip i hela grupp 1, vilket tyder på att det finns en stark norm att utforma texter på detta sätt. Andra resurser, som runstorlek eller radlängd (varianterna där lässtart erbjuds genom större runformer eller längre rad), förekommer inte lika konsekvent. Man kan tänka sig att dessa resurser är centrala i skriftkulturen men att det här finns ett något större utrymme för variation. Mer infrekventa resurser som skiljetecken eller runtäthet kan då förstås som mindre centrala resurser. Andra resurser, som varianten av runstorlek där startraden markeras med mindre runor, är så infrekventa att det möjligen kan ifrågasättas huruvida de är en del av textkonventionen överhuvudtaget. Eventuellt har de kommit till av en tillfällighet. Samtidigt finns mycket infrekventa resurser som ändå har en otvetydig funktion för läsordning, exempelvis olika radriktning (grupper av rader som ligger vertikalt respektive horisontellt läses för sig). Det verkar alltså finnas vissa mycket klara konventioner för hur runristningar komponeras, samtidigt som materialet visar stor variation och en öppenhet för en användning av just de resurser som passar en viss inskrifts behov. Att skilja rader åt genom riktning är exempelvis sällan nödvändigt i korta inskrifter, vilket majoriteten av materialet består av.

Om och i så fall hur tydliga respektive otydliga resurser kan kopplas till skriftnormer är svårare att säga. En tydlig resurs kanske är utformad så just eftersom den inte är en central del av textkonventionen. Det finns emellertid exempel på kompositioner vars startrad markerats mycket tydligt med stora runor, exempelvis DR 248 Snoldelev (se fig. 7), samtidigt som just stora runor är ett visuellt drag som förekommer väldigt ofta för att markera lässtart vilket tyder på att den är central för skriftkulturen. Omvänt kanske en resurs som är central inom skriftkulturen kan utformas otydligt just eftersom den är central. Det verkar alltså inte finnas något givet samband mellan hur central en resurs kan antas vara inom textkonventionen och graden av tydlighet.

Fler omständigheter än frekvens och tydlighet kan berätta om den tidigvikingatida skriftkulturen. Gemensamt för många av de resurser som uttrycker framskjutenhet, och som framförallt erbjuder lässtart, är till 
exempel att det finns fler varianter av en resurs. Bland annat kan radlängd innebära att lässtart i vissa kompositioner markeras med en lång rad medan den i andra markeras med en kort. Resursen är alltså snarast relativ; det är i förhållande till hur den fungerar i den övriga kompositionen, det vill säga hur långa eller korta de övriga raderna är, som resursens betydelse realiseras. Det innebär också att det inte finns en viss absolut längd som uttrycker framskjutenhet. Ibland gäller snarare ett motsatsförhållande; ett skiljetecken kan till exempel markera lässtart antingen genom sin närvaro eller sin frånvaro. Vidare är den mest frekvent förekommande varianten av resurserna oftast den som har större storlek; större runor erbjuder lässtart oftare än mindre, längre rad oftare än kortare och så vidare. Förmodligen beror detta på att det som är större till storleken lättare sticker ut än det som är mindre och därmed uttrycker framskjutenhet mer effektivt. Sammanfattningsvis verkar den betydelseskapande potentialen för de resurser som uttrycker framskjutenhet i första hand finnas i hur något avviker visuellt från den övriga kompositionen, inte i det specifika visuella draget. Detta kan förklara varför så många olika typer av resurser som realiserar framskjutenhet återfinns i materialet och varför resursvarianter av mindre storlek ibland förekommer trots att de är sämre lämpade att uttrycka framskjutenhet. Den styrande normen för hur text utformas är kanske att överhuvudtaget markera lässtart genom en (valfri) visuell resurs som på något sätt skapar framskjutenhet, vilket ger utrymme för stor variation vad gäller det specifika utförandet. Emellertid kan en sådan slutsats åtminstone delvis vara resultatet av ett cirkelresonemang; en utgångspunkt för studien är att den språkligt givna lässtarten ska vara just visuellt framskjuten. Dock är min uppfattning att detta antagande bekräftas av hur materialet faktiskt ser ut.

Studiens andra syfte är att använda de identifierade läsordningsprinciperna för att föreslå visuellt erbjuden läsordning för tre texter (Bo Boije4 Skee, DR NOR1988;5 Malt och U ANF1937;163 Björkö) i det tidigvikingatida runmaterialet vars läsordning inte är språkligt given. Den undersökningsmodell som föreslås innebär att de tre texterna först studeras för att identifiera vilka av de urskilda visuella resurserna som återfinns där. I alla tre fall indikerar resurserna ifråga flera olika alternativa läsordningar. För att väga dessa alternativ mot varandra används graderingen av resurserna i starkt respektive svagt markerade erbjudanden om läsordning, där företräde alltså ges åt det alternativ som erbjuds starkast. För alla tre ristningarna går resurserna att använda för att bestämma vilka läsordningar som texten erbjuder visuellt (se de tre sammanfattningarna ovan). I några fall har resurserna varit otillräckliga för att beskriva egenheter i de tre 
kompositionerna och paralleller från det övriga runmaterialet har då använts som komplement. Framförallt gäller det hur kompositioner vars rader löper bustrofedon fungerar. Med de tre exempelanalyserna vill jag visa att även om de visuella resurser som urskilts visserligen är intressanta i sig, i och med att de kan ge oss en inblick i tidigvikingatida skriftkultur, kan de också användas för att analysera läsordning i andra kompositioner. Vidare vill jag ge prov på att runristningars visualitet är central för att bestämma läsordning, och relevansen av ett sådant perspektiv kanske är som mest påtaglig då det kommer till svårtolkade inskrifter där vi, så som i de tre exempelanalyserna, inte har tillgång till ett språkligt innehåll som klart kan indikera en viss läsordning. Fördelen med att fokusera på den visuella kompositionen är att ett resonemang kring läsordning då kan föras innan inskriften tolkats. De ordningar som är mest sannolika utifrån endast visuella kriterier kan sedan fungera som ett stöd för den språkliga tolkning som följer någon av dessa läsordningar.

Läsordning kan undersökas vidare på flera olika sätt. Föreliggande studie har begränsats till textens visuella erbjudande om läsordning samt att diskutera läsning av runinskrift som ett linjärt fenomen. I exempelanalyserna väger jag visserligen olika linjära erbjudanden mot varandra, men syftet har inte varit att utforska till exempel huruvida flera av dem kan samexistera eller om icke-linjära alternativ är tänkbara. En väg att gå är därmed att vidga undersökningen till att vid sidan om textens visuella erbjudande även ta hänsyn till den språkligt erbjudna läsordningen, det vill säga den läsordning som indikeras genom att det språkliga innehållet blir begripligt, samt öppna för att runtexter hypotetiskt skulle kunna vara både linjära och icke-linjära. I det följande ska några prelimära iakttagelser göras.

Det varierar i vilken utsträckning inskriftens språkliga innehåll kräver att de ingående elementen läses i en viss bestämd ordning för att bli begripligt. En indikation på detta kan man få genom uppdelningen av materialet i grupp 1 och 2 . I grupp 1 placeras flerradiga kompositioner som helt (13 stycken) eller delvis (14 stycken) kan få sin läsordning bestämd på språklig grund; i dessa texter finns alltså ett språkligt erbjudande om en specifik läsordning. (Utifrån antagandet att ett språkligt erbjudande om en viss läsordning finns då inskriften uppfyller de kriterier jag formulerat för grupp 1.) I grupp 2 gäller det motsatta; i dessa inskrifter kan läsordningen (helt eller delvis) inte bestämmas på språklig grund och textens rent språkliga erbjudande om läsordning är därmed svagt. Det ska dock påpekas att i de flesta fall är anledningen till att läsordningen inte kan bestämmas på språklig grund att inskrifterna är bara delvis eller osäkert tolkade eller helt otolkade, antingen på grund av skador eller svårtydda 
runföljder. Endast åtta (av totalt 62 flerradiga kompositioner) är placerade i grupp 2 utan att kategoriseringen i första hand beror på den typen av svårigheter (se vidare nedan). Även om de flerradiga ristningarna i mitt material alltså oftast rymmer ett språkligt erbjudande om en viss läsordning genom hela inskriften, visar samtidigt dessa åtta ristningar att texter med en språkligt öppen läsordning har en plats i den tidigvikingatida skriftkulturen. Att det är en glidande skala mellan dessa båda ytterligheter visar dessutom de 14 kompositioner vars läsordning endast delvis kan bestämmas på språklig grund.

Vidare framgår, om man tittar på både de språkligt och visuellt erbjudna läsordningarna samtidigt, att dessa inte alltid kompletterar varandra. I grupp 1 kan det som jag visat i ett antal fallbeskrivningar ovan variera stort i vilken utsträckning den språkligt grundade läsordningen även erbjuds visuellt. I de åtta inskrifterna i grupp 2 kan man dessutom se att avsaknaden av ett tydligt språkligt erbjudande om läsordning inte alltid betyder att texten rymmer ett starkt markerat visuellt erbjudande (så i fyra kompositioner: DR 211 Nørre Nærå, ?G 225 Svenskens, Sm NOR2001;25 Tunnerstad och troligen Ribekammen, utan signum). Samtidigt finns i fyra av de åtta kompositionerna (N A210 Slemmedal, N A211 [två signum som hör till samma komposition], DR 105 Laurbjerg, DR 239 Gørlev 1 och Ög 43 Ingelstad) ett starkt markerat visuellt erbjudande.

Även om man tittar på den visuellt respektive språkligt erbjudna läsordningen samtidigt verkar det alltså finnas en glidande skala i vilken utsträckning de olika resurstyperna förekommer. I vissa ristningar är det kanske helt enkelt inte möjligt att vare sig visuellt eller språkligt identifiera ett entydigt linjärt erbjudande om läsordning. Jag tror inte det behöver ses som ett problem. Istället för att ändå försöka bestämma en ordning kan det vara mer fruktbart att diskutera varför kompositionen är komponerad på ett sätt där detta inte är möjligt och vad ett sådant förhållningssätt till textstrukturering säger om den tidigvikingatida skriftkulturen. Det kan exempelvis tyda på att denna kultur vid sidan om sådana ristningar med ett starkt markerat visuellt erbjudande om läsordning (eller en språkligt grundad motsvarighet) rymmer relativt dynamiska texter med möjlighet för en mottagare att välja olika vägar genom texten. Det ger en indikation på ett tidigvikingatida förhållningssätt till skrift, som kännetecknas av att inskriften visserligen är linjär i den meningen att en runföljd i en rad löper linjärt, men att den samlade skriftmassan inte behöver ha en enda bestämd ordningsföljd, varken visuellt eller språkligt. Att presentera språkligt innehåll på detta sätt är en möjlighet som finns i skriftliga medier till skillnad från i tal. I den skriftkultur som växer fram under tidig 
vikingatid tycks detta alltså i olika hög grad ha utnyttjats. Ytterligare en aspekt av detta förhållningssätt till text är att handlingsutrymme överlåts till mottagaren, det vill säga mottagaren ges fler val och blir därmed mer aktiv vad gäller att komponera sin egen läsning av texten (jfr diskussion hos Kress 2005, 6-11). Om man ska tala om ett avsändar- och mottagarförhållande ger avsändaren/ristaren på detta sätt upp en del av kontrollen över texten. Samtidigt är det relativt sällan som helt fria läsordningar förekommer. Den visuella kompositionen och det språkliga innehållet både möjliggör och begränsar läsarens valfrihet.

Ska den språkligt erbjudna läsordningen tas hänsyn till måste den undersökas i sin egen rätt. En bedömning måste göras av vilka språkliga resurser som indikerar en viss läsordning. Exempelvis kan man fråga sig i vilken mån satser avslutas i radslut och vad sådana avbrott innebär för att skapa en entydig eller tvetydig ordning mellan visuella element. En annan fråga gäller vikten av en språklig struktur, som formlers inbördes ordning i minnesinskrifter, för att en mottagare ska kunna avgöra läsordning. Vidare skulle andra läsordningar än de själva texten erbjuder kunna uppmärksammas. Ett mottagarperspektiv med ett resonemang kring faktiska läsares beteenden skulle exempelvis kunna innebära att läsordning betraktas mer dynamiskt, något som växer fram allteftersom mottagaren dechiffrerar inskriften. Vilka rader som tillsammans ger mening och vilka visuella resurser som i en viss komposition indikerar att just dessa rader hör ihop är inget mottagaren måste ha vetat på förhand, och processen att arbeta sig igenom en inskrift från början till slut kan ha krävt flera misslyckade försök innan en språkligt och visuellt fungerande läsordning kunde bestämmas. Förutom mottagarens perspektiv kan det också vara intressant att resonera kring huruvida ristarens arbetsprocess, i den mån den går att fastställa, säger något om läsordning, samt om den är identisk med den språkligt och visuellt erbjudna ordningen. Slutligen skulle läsordningsprinciper också kunna undersökas i ett större material. Mycket återstår alltså att göra. Mitt bidrag hoppas jag gör klart att det oavsett omfattning på studie är viktigt att specificera från vilket perspektiv läsordningen undersöks och motivera på vilka grunder argumenten byggs. ${ }^{21}$

\section{Förteckning över indelningen av undersökningsmaterialet i grupp 1 och 2}

${ }^{21} \mathrm{Jag}$ vill tacka de två anonyma fackgranskarna för deras mycket konstruktiva synpunkter på både innehåll och presentation.

Futhark 9-10 (2018-2019) 


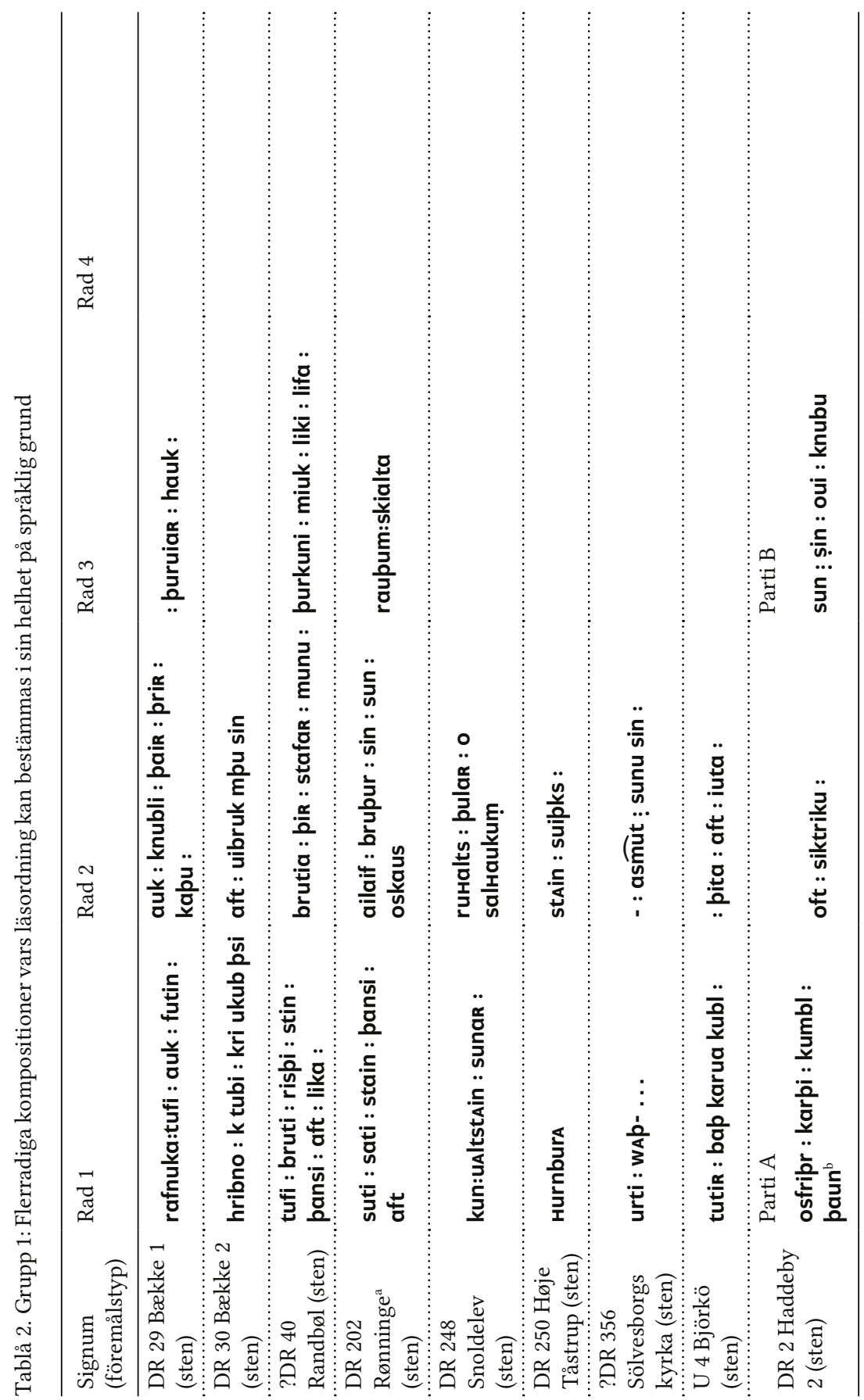

Futhark 9-10 (2018-2019) 


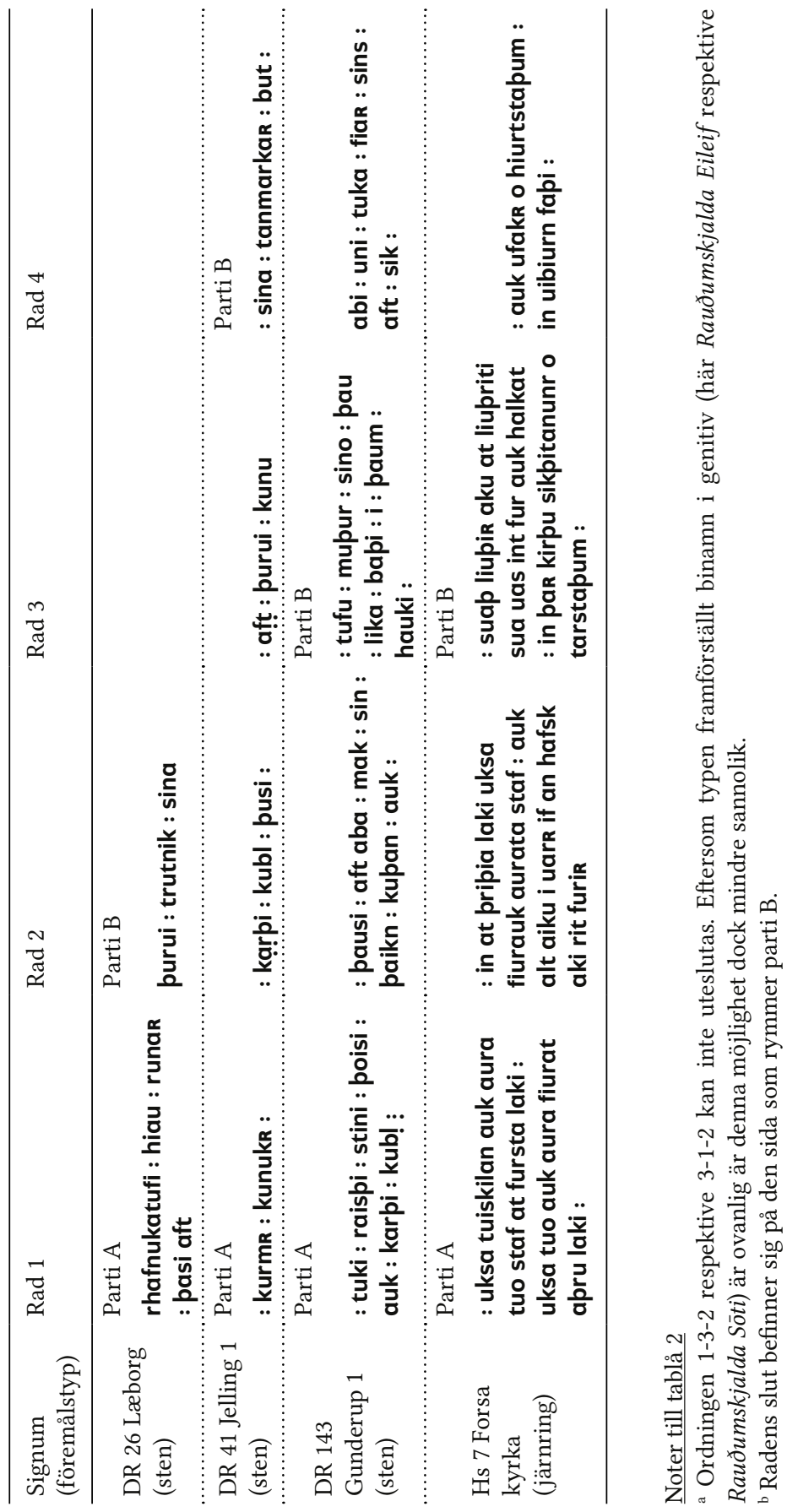

Futhark 9-10 (2018-2019) 
Tablå 3. Grupp 1 och 2: Flerradiga kompositioner vars läsordning inte kan bestämmas i sin helhet på språklig grund. Här återges den allmänt vedertagna läsordningen.

\begin{tabular}{|c|c|c|c|c|}
\hline $\begin{array}{l}\text { Signum } \\
\text { (föremålstyp) }\end{array}$ & 苛. & ॠ్ర & Läsning & $\begin{array}{l}\text { Ordningsföljder } \\
\text { som ingår i grupp } 1\end{array}$ \\
\hline $\begin{array}{l}\text { DR } 190 \\
\text { Helnæs (sten) }\end{array}$ & & $\begin{array}{l}1 \\
2 \\
3 \\
4\end{array}$ & $\begin{array}{l}\text { rHuulfR sati stain nuRa } \\
\text { kupi aft kupumut brupur } \\
\text { sunu sin truknapu --... } \\
\text { ouair fapi }\end{array}$ & $\begin{array}{l}\text { Rad 1-2-3 } \\
\text { Kompositionens } \\
\text { lässtart: Osäker }\end{array}$ \\
\hline $\begin{array}{l}\text { DR } 192 \\
\text { Flemløse } 1 \\
\text { (sten) }\end{array}$ & & $\begin{array}{l}1 \\
2 \\
3 \\
4\end{array}$ & $\begin{array}{l}\text { Aft ruulf stotr } \\
\text { [st] }]_{\text {Ain SASi is uAs nu }} \\
\text { Ra kupi satu su[niR aftir } \\
\text { ouAiR faapi] }\end{array}$ & $\begin{array}{l}\text { Rad 1-2-3 } \\
\text { Kompositionens } \\
\text { lässtart: Osäker }\end{array}$ \\
\hline $\begin{array}{l}\text { ?G } 280 \\
\text { Pilgårds } \\
\text { (sten) }\end{array}$ & & $\begin{array}{l}1 \\
2 \\
3 \\
4 \\
5 \\
6 \\
7\end{array}$ & $\begin{array}{l}\text { biarfaa : statu : sis[o] stain } \\
\text { hakbiarn : brupr } \\
\text { rupuisl : austain : imuar } \\
\text { is af[a] : st[ai]n[a] : stata : aft : } \operatorname{raf}[\mathbf{a}] \\
\text { su[b] furi : ru[f]staini : kuamu } \\
\text { uit i aifur : uifil } \\
\text { [ba]up [um] }\end{array}$ & $\begin{array}{l}\text { Rad } 4 \text { följer på } 3 \\
\text { eller } 2 \\
\text { Rad 5-6 } \\
\text { Kompositionens } \\
\text { lässtart: Osäker }\end{array}$ \\
\hline $\begin{array}{l}\text { Ög N288 } \\
\text { Oklunda } \\
\text { (stenhäll) }\end{array}$ & & $\begin{array}{l}1 \\
2 \\
3 \\
4 \\
5\end{array}$ & $\begin{array}{l}\text { kunar : fapi runar } \\
\text { pisar : in sa flau sakir : } \\
\text { suti ui pita : in sa fl- } \\
\text { ị rup pan : in sa bat } \\
\text { uifin : pit tafapi : }\end{array}$ & $\begin{array}{l}\text { Rad 1-2 } \\
\text { Kompositionens } \\
\text { lässtart: Rad } 1\end{array}$ \\
\hline $\begin{array}{l}\text { DR EM85; } \\
\text { 151B Ribe } \\
\text { (bit av } \\
\text { kranium) }\end{array}$ & & $\begin{array}{l}1 \\
2 \\
3 \\
4\end{array}$ & $\begin{array}{l}\text { ulfur auk upin Auk Hutiur : HiAlb buris } \\
\text { : uipR } \\
\text { PAimA uiarki Auk tuir } \\
\text { kunin } \\
\text { buur }\end{array}$ & $\begin{array}{l}\text { Rad 1-2-3 } \\
\text { Kompositionens } \\
\text { lässtart: Osäker }\end{array}$ \\
\hline $\begin{array}{l}\text { DR MLUHM } \\
\text { 1983-84;131 } \\
\text { Lilla Köpinge } \\
\text { (kam) }\end{array}$ & & $\begin{array}{l}1 \\
2 \\
3 \\
4\end{array}$ & $\begin{array}{l}\text { urmiltr ku } \\
\text { ap pat } \\
\text { kku } \\
\text { ụạlinịi... }\end{array}$ & $\begin{array}{l}\text { Rad 1-2 } \\
\text { Kompositionens } \\
\text { lässtart: Osäker }\end{array}$ \\
\hline $\begin{array}{l}\text { DR } 4 \\
\text { Haddeby } 4 \\
\text { (sten) }\end{array}$ & $\begin{array}{l}\mathrm{B} \\
\mathrm{C}\end{array}$ & $\begin{array}{l}1 \\
2 \\
3^{\mathrm{c}} \\
4^{\mathrm{d}} \\
5 \\
6\end{array}$ & $\begin{array}{l}\text { : osfripr : karpi } \\
\text { kubl : pausi : tutiR : upinka } \\
\text { u } \\
\text { rs : oft : siktriuk : kunuk : : sun : sin : } \\
\text { : auk : knubu : } \\
\text { kurmR : raist : runạR : }\end{array}$ & $\begin{array}{l}\text { Rad 1-2-3-4-5 } \\
\text { Lässtart i parti A: } \\
\text { Rad } 1 \\
\text { Kompositionens } \\
\text { lässtart: parti A } \\
\text { eller C }\end{array}$ \\
\hline
\end{tabular}

Futhark 9-10 (2018-2019) 


\begin{tabular}{|c|c|c|c|c|}
\hline $\begin{array}{l}\text { Signum } \\
\text { (föremålstyp) }\end{array}$ & 刍. & 䒿 & Läsning & $\begin{array}{l}\text { Ordningsföljder } \\
\text { som ingår i grupp } 1\end{array}$ \\
\hline $\begin{array}{l}\text { DR } 110 \\
\text { Virring (sten) }\end{array}$ & A & $\begin{array}{l}1 \\
2 \\
3 \\
4 \\
5 \\
6\end{array}$ & $\begin{array}{l}\text { : ki-mutr : } \\
\ldots \ldots \text { : kạpi } \\
\text { : mịni : --ụ : aft : } \\
\text { : sasur : star } \\
\text { rịspi : stin : aft : tupan : } \\
\text { pur : uiki : pisi : kuml : }\end{array}$ & $\begin{array}{l}\text { Rad 2-3-4 } \\
\text { Lässtart i parti A: } \\
\text { Rad } 1 \text { eller } 2 \\
\text { Kompositionens } \\
\text { lässtart: Parti A } \\
\text { eller B }\end{array}$ \\
\hline $\begin{array}{l}\text { DR } 189 \\
\text { Avnslev } \\
\text { (sten) }\end{array}$ & A & $\begin{array}{l}1 \\
2 \\
3 \\
4\end{array}$ & $\begin{array}{l}{[\ldots \text {-oottr stain }]} \\
{[\text { sasi sati ru... }]} \\
{[\ldots \text { karpi auk }]} \\
{[\text { ruulf̣. .... }}\end{array}$ & $\begin{array}{l}\text { Rad 1-2 } \\
\text { Kompositionens } \\
\text { lässtart: Osäker }\end{array}$ \\
\hline $\begin{array}{l}\text { DR } 209 \\
\text { Glavendrup } \\
\text { (sten) }\end{array}$ & A & $\begin{array}{c}1 \\
2 \\
3 \\
4 \\
5 \\
6 \\
7 \\
8 \\
9 \\
10 \\
11 \\
12 \\
13 \\
14\end{array}$ & $\begin{array}{l}\text { raknhiltr : sa } \\
\text { ti : stain ponsi : auft } \\
\text { ala : saulua kupa } \\
\text { uia lịps haipuiarpan pia } \\
\text { kn } \\
\text { ala : sunir : karpu } \\
\text { kubl : pausi : aft : fapur } \\
\text { sin : auk : hons : kuna : auft } \\
\text { uar : sin : in : suti : raist : run } \\
\text { ar : pasi : aft : trutin : sin } \\
\text { pur : uiki : pasi : runar } \\
\text { at : rita : sa : uarpi : is : stain pansi } \\
\text { ailti : ipa } \\
\text { aft : onon : traki }\end{array}$ & $\begin{array}{l}\text { Rad 1-2, 4-5 } \\
\text { Rad 6-7-8-9-10 } \\
\text { Rad 12-13-14 } \\
\text { Lässtart i parti A: } \\
\text { Rad 1 } \\
\text { Lässtart i parti B: } \\
\text { Rad } 6 \text { eller 11 } \\
\text { Lässtart i parti C: } \\
\text { Rad 12 } \\
\text { Parti A-B (osäkert!) } \\
\text { Parti C avslutar } \\
\text { kompositionen }\end{array}$ \\
\hline $\begin{array}{l}\text { DR } 230 \\
\text { Tryggevælde } \\
\text { (sten) }\end{array}$ & $\begin{array}{l}\mathrm{B} \\
\mathrm{C}\end{array}$ & $\begin{array}{l}1 \\
2 \\
3 \\
4 \\
5\end{array}$ & $\begin{array}{l}\text { raknhiltr : sustir : ulfs : sati : stain } \\
\text { pnnsi : auk : karpi : hauk : ponsi auft } \\
\text { auk skaip : paisi } \\
\text { kunulf : uar sin : klomulan man } \\
\text { șun : nairbis : fair : uarpa : nu futir : } \\
\text { poi batri } \\
\text { sa uarpi : at : rita : is ailti stain ponsi } \\
\text { ipa hipan traki }\end{array}$ & $\begin{array}{l}\text { Rad 1-2-4-5 } \\
\text { Lässtart i parti A: } \\
\text { Rad } 1 \\
\text { Rad } 5 \text { avslutar } \\
\text { parti A } \text { f }^{\text {f }} \\
\text { Parti A-B-C }\end{array}$ \\
\hline $\begin{array}{l}\text { Sm } 144 \\
\text { Gursten } \\
\text { (sten) }\end{array}$ & $\begin{array}{l}\mathrm{A} \\
\mathrm{B}\end{array}$ & $\begin{array}{l}1 \\
2 \\
3 \\
4 \\
5\end{array}$ & $\begin{array}{l}\text { kupaskaki fapi } \\
\text { sunur na } \\
\text { ut smip } \\
\text { a kata } \\
\text { uif sipar un... }\end{array}$ & $\begin{array}{l}\text { Rad 2-3-4 } \\
\text { Kompositionens } \\
\text { lässtart: Osäker }\end{array}$ \\
\hline $\begin{array}{l}\text { Ög } 8 \\
\text { Kälvesten } \\
\text { (sten) }\end{array}$ & A & $\begin{array}{l}1 \\
2 \\
3 \\
4\end{array}$ & $\begin{array}{l}\text { stikur : karpi kubl pạ̣ } \\
\text { aft auint sunu sin : sa fial austr } \\
\text { miR aiuisli : uikikr fapi } \\
\text { aukrimulfR }\end{array}$ & $\begin{array}{l}\text { Rad 1-2 } \\
\text { Kompositionens } \\
\text { lässtart: Rad } 1 \\
\text { Parti A-B }\end{array}$ \\
\hline
\end{tabular}




\begin{tabular}{|c|c|c|c|c|}
\hline $\begin{array}{l}\text { Signum } \\
\text { (föremålstyp) }\end{array}$ & 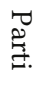 & ஜृँ̃ & Läsning & $\begin{array}{l}\text { Ordningsföljder } \\
\text { som ingår i grupp } 1\end{array}$ \\
\hline \multirow{29}{*}{$\begin{array}{l}\text { Ög } 136 \text { Rök }^{\mathrm{h}} \\
\text { (sten) }\end{array}$} & A & 1 & aft uamup stonta runar par : & \multirow{29}{*}{$\begin{array}{l}\text { Rad 1-2, 5-6, 9-10- } \\
11 \\
\text { Rad 12-13-14-15- } \\
\text { 16-17-18-19 } \\
\text { Rad 22-23 } \\
\text { Rad 24-25-26 } \\
\text { Lässtart i parti A: } \\
\text { Rad 1 } \\
\text { Lässtart i parti C: } \\
\text { Osäker } \\
\text { Kompositionens } \\
\text { lässtart: Rad 1 } \\
\text { Parti A-B } \\
\text { Parti A-B föregår } \\
\text { parti C }\end{array}$} \\
\hline & & 2 & in uarin fapi fapir aft faikion sunu & \\
\hline & & 3 & $\begin{array}{l}\text { sakumukmini pat huariar ualraubar } \\
\text { uaRin tuaR }\end{array}$ & \\
\hline & & 4 & $\begin{array}{l}\text { par suap tualf sinum uarinumnar } t \\
\text { ualraubu }\end{array}$ & \\
\hline & & 5 & $\begin{array}{l}\text { bapar somon o umisumonum : pat } \\
\text { sakum ona }\end{array}$ & \\
\hline & & 6 & rt huar fur niu altum on urpi fiaru & \\
\hline & & 7 & miR hraipkutum auk tu & \\
\hline & & 8 & mir on ub sakar & \\
\hline & & 9 & raipiauriks hin purmupi stilik & \\
\hline & & 10 & $\begin{array}{l}\text { flutna strontu hraipmarar sitiR nu } \\
\text { karuR o }\end{array}$ & \\
\hline & $\mathrm{B}$ & 11 & $\begin{array}{l}\text { kuta sinum skialti ub fatlapr skati } \\
\text { marika }\end{array}$ & \\
\hline & \multirow[t]{12}{*}{$\mathrm{C}$} & 12 & pat sakum tualfta huar histr si ku & \\
\hline & & 13 & nar ituituoki on kunukar tuair tikir & \\
\hline & & 14 & p o likia : pat sakum pritaunta huaris $t$ & \\
\hline & & 15 & uair tikir kunukar satin $\mathrm{t}$ siulunti fia & \\
\hline & & 16 & kura uintur at fiakurum nabnum burn & \\
\hline & & 17 & $\begin{array}{l}\text { ị fiakurum bruprum : ualkaR fim } \\
\text { rapulfsu }\end{array}$ & \\
\hline & & 18 & $\begin{array}{l}\text { niR hraipulfar fim rukulfsuniR hoislar } \\
\text { fim harup }\end{array}$ & \\
\hline & & 19 & s sunir kunmuntar fim ḅirnar sunir : & \\
\hline & & 20 & $\begin{array}{l}\text { nuk m-- m-- alu --kị ainhuar - p... } \\
\ldots p \ldots\end{array}$ & \\
\hline & & $21^{\mathrm{i}}$ & ftir fra & \\
\hline & & 22 & SAGWMOGMEni pad HOaR iGold & \\
\hline & & 23 & ịGa OaRi Goldin D Goonar Hosli & \\
\hline & \multirow[t]{3}{*}{$\mathrm{C}$} & 24 & airfbfrbnhn finb an tfonhnu & \\
\hline & & 25 & $\mathbf{R}$ troki uilin is pat : rhfp rhis & \\
\hline & & 26 & iatun uilin is : pat $\langle$ nịt $\rangle$ & \\
\hline & $\mathrm{D}$ & 27 & $\langle$-akumukmini pur〉 & \\
\hline & $\mathrm{E}$ & 28 & $\langle$ si $\rangle$ bi $\langle u i\rangle a\langle u a\rangle$ ri & \\
\hline & $\mathrm{C}$ & 29 & $\langle u l$ niru $\rangle p_{R}$ & \\
\hline
\end{tabular}


Noter till tablå 3

${ }^{a}$ Jag utgår från Källströms (2007, 100 f.) tolkning eftersom denna tar hänsyn till dubbelskrivning av $\mathbf{t}$-runorna, samt undviker en problematisk ordföljd med verbet på tredje plats i satsen som följer av om man ser rad 5 som en självständig sats. Jfr dock Fridell och Óskarsson 2011, $147 \mathrm{f}$.

b Jag följer Stoklunds $(1996,205 ; 2004,37)$ tolkning. Ordningen 1-4-2-3 är möjlig men semantisk osannolik. Vidare skulle rad 2 och 3 eventuellt kunna räknas som en enda rad. Runorna i början på rad 3 är vinklade mot slutet av rad 2. Men eftersom runorna i rad 3 därefter helt byter riktning jämfört med dem i rad 2 bedömer jag rad 3 som en egen rad (jfr t.ex. N 140 Valby som bedöms som en enda rad).

${ }^{\mathrm{c}}$ Rad 3 delar ramlinjer med rad 1 men har bedömts som en egen rad p.g.a. att runföljderna har olika läsriktning; rad 1 löper nedifrån och upp medan rad 3 löper uppifrån och ned.

${ }^{\mathrm{d}} \mathrm{Rad} 4$ sträcker sig egentligen över till parti B.

e Tolkningen av saulua kupa uia lịps haipuiarpan piakn är osäker (se t.ex. Kousgård Sørensen 1989, 17-26 m. litt.) och därför antar jag inte att ordningen rad 3-4 kan bestämmas på språklig grund.

${ }_{\mathrm{f}}$ Möjligen är det osäkert om ordningen 1-2-4-5 är språkligt given eftersom det finns syntaktiska oregelbundenheter i inskriften ( $r a d 3$ går inte att passa in). Jag räknar emellertid med denna ordning eftersom det innebär att flest rader ingår i ett syntaktiskt sammanhang, samtidigt som det semantiska sammanhanget är rimligt.

${ }^{g}$ För Sm 144 utgår jag från min egen tolkning (se Åkerström 2012, 47), men oavsett om t.ex. Kinanders (i SRI, 4: 293) eller von Friesens $(1914,4)$ tolkningar hade använts kan läsordning bestämmas på språklig grund i lika hög utsträckning.

${ }^{\mathrm{h}}$ Jag utgår från Gustavson 2003 som bygger på Wessén 1958. Med anledning av inskriftens komplicerade karaktär och osäkra tolkningar (se t.ex. Ralph 2007, Holmberg 2016, Holmberg et al. 2020) utgår jag inte från att denna tolkning måste stämma, och är mycket sparsam med vilka ordningsföljder mellan element jag bedömer som språkligt givna. I första hand räknar jag med en viss ordningsföljd i de fall det verkar som om radbyte sker mitt i ett ord. Dessutom räknar jag med att versen i fornyrðislag som sträcker sig över parti A och B visar på ordningsföljden rad 9-10-11.

${ }^{\mathrm{i}}$ Möjligen är det tveksamt om rad 21 ska bedömas som en egen rad. Ett avstånd finns emellertid mellan denna och slutet av rad 19 respektive 20 . 
Tablå 4. Grupp 1: Kompositioner med endast en rad

\begin{tabular}{ll}
\hline Ristningar på sten & Ristningar på lösföremål \\
\hline Bo KJ80 Rävsal & DE EM85;370 Elisenhof \\
Bo Peterson1992 Hoga & DR 100B Viborg \\
DR 9 Nørre Brarup † & DR EM85;160 Ålborg \\
DR 15 Øster Løgum & DR EM85;370B Haddeby \\
DR 17 Starup & DR NOR2003;6 Duesminde \\
DR 144 Gunderup 2 & G 355 utan proveniens \\
?DR 191 Sønderby & ?G 389 Bottarve \\
DR 193 Flemløse 2 & N 127 Hon \\
DR DKFyn51 Faaborg & N 137 Oseberg 1 \\
?DR EM85;377 Älleköpings kyrka ${ }^{\text {b }}$ & N 138 Oseberg 2 \\
?G 40 Roes & ?N 450 Strand \\
N 2 Bjørneby & ?N 458 Gravråk \\
N 140 Valbyc & N 579 Kaupang \\
N 209 Oddernes 1 & N A212 Slemmedal \\
Ög 38 Boberg & U ANF1937;180 Långtora \\
& U Fv1913;276 Björkö \\
& ?RU Melnikova2001;189 Gorodishche 2 \\
& RU NLT2004;5 Staraja Ladoga runpinne \\
& Öl BN83 Klinta 1 \\
?Öl NOR2003;26 Räpplinge \\
\hline
\end{tabular}

\section{Noter till tablå 4}

a Jfr dock uppgifter i databasen Danske Runeindskrifter om senare bearbetning av stenen.

${ }^{\mathrm{b}}$ Jfr dock uppgifter i databasen Danske Runeindskrifter om senare bearbetning av stenen.

${ }^{\mathrm{c}}$ Kompositionens enda rad kan möjligen analyseras som två. Den sista delen svänger av i en skarp vinkel och runorna löper därför inte helt i en och samma riktning. Men eftersom runorna är placerade nära varandra och eftersom de i sista delen av raden inte helt byter riktning räknar jag runföljden som en rad.

d Charlotte Blindheim $(1982,23)$ påpekar att de två beslag som rymmer N A210 och N A211 respektive N A212 kan ha suttit på samma eller på olika halskedjor. Hade man säkert kunnat konstatera att alla tre ristningarna funnits på samma smycke skulle möjligen smycket i sig kunna ha bedömts som en enda komposition. Nu har de emellertid bedömts som två. 
Tablå 5. Grupp 2: Flerradiga kompositioner som endast ingår i grupp 2

\begin{tabular}{ll}
\hline Ristningar på sten & Ristningar på lösföremål \\
\hline Bo Boije4 Skee & DR 263 Skabersjö \\
DR 105 Laurbjerg & DR EM85;348 Lindholm \\
DR 211 Nørre Nærå & DR EM85;350 Hemdrup \\
DR 221 Vordingborg & ?DR EM85;371A Haddeby \\
DR 239 Gørlev & DR EM85;371B Haddeby \\
?DR 254 Herlev & ?G 225 Svenskens \\
DR 333 Örja & G 361 Hallbjäns \\
DR NOR1988;5 Malt & N 139 Gokstad \\
DR NOR1998;21 Färlöv & N 282-N 284 Trå 1-Trå 3 \\
?G 110 Tjängvide & N A210-N A211 Slemmedal \\
G 157 Gothems kyrka & Ribe, kam (utan signum) \\
?G 252 Lokrume kyrka & ?RU Melnikova2001;196 Staraja Ladoga amulett \\
G 310 Hangvars kyrka & ?RU Melnikova2001;181 Gorodishche 1 \\
?Sm 20 Rottnekvarn $\dagger$ & U ANF1937;163 Björkö \\
Sm NOR2001;25 Tunnerstad & U ANF1937;172 Björkö \\
Sö 176 Kärnbo ödekyrka & U AST1;150 Ulvsunda \\
U 9 Björköa & ?U NOR1994;26A Alsnö hus \\
U 752 Viggby & U NOR2002;26 Björkö bleck 1 \\
U ATA3916/47 Finsta & U NOR2002;28 Björkö bleck 2 \\
Vg 119 Sparlösa & Öl BN84 Klinta 2 \\
Ög 43 Ingelstad & \\
Ög 117 Slaka kyrka & \\
?Öl 33 Runstens kyrkoby $†$ & \\
\hline
\end{tabular}

Not till tablå 5

${ }^{a}$ U 9 rymmer enligt Källström (2013, 108, not 5) fragment från fem olika kompositioner. 
116 • Hanna Åkerström

Tablå 6. Grupp 2: Skadade ristningar som kan ha haft fler än en rad

\begin{tabular}{ll}
\hline Ristningar på sten & Ristningar på lösföremål \\
\hline DR 34 Horne ${ }^{\mathrm{a}}$ & DR AUD1993;261 Ribe \\
DR 70 Hammel 1 & ?DR DKNJy76 Sofiendal \\
DR 188 Ørbæk $\dagger$ & DR NOR2001;8A Hörup \\
?DR 323 Lilla Harrie & DR NOR2001;8B Hörup \\
G 109 Ollaifs & N 537 Engstad \\
G 186 Stenhuse $\dagger^{\text {b }}$ & N 578 Oseberg 3 \\
G 187 Stenhuse & U ANF1937;178B Björkö \\
?G 248 Riddare & U ANF1937;179 Björkö \\
?G 266 Stenkyrka kyrka & U NOR2001;24 Björkö \\
?G 305 Hangvars kyrka & Ribe, benplatta (utan signum) \\
?N 300 Eikeland & Birka, runben (utan signum) \\
U 5 Björkö & \\
U Fv1921(2);14 Björkö & \\
\hline
\end{tabular}

Noter till tablå 6

${ }^{a}$ Egentligen består DR 34 av en slinga, inte en rad.

b Enligt Elisabeth Svärdström (i SRI, 12: 128) utgör möjligen G 186 och G 187 delar av samma sten; i så fall borde de bedömas som två rader i en och samma komposition. 


\section{Figurer}

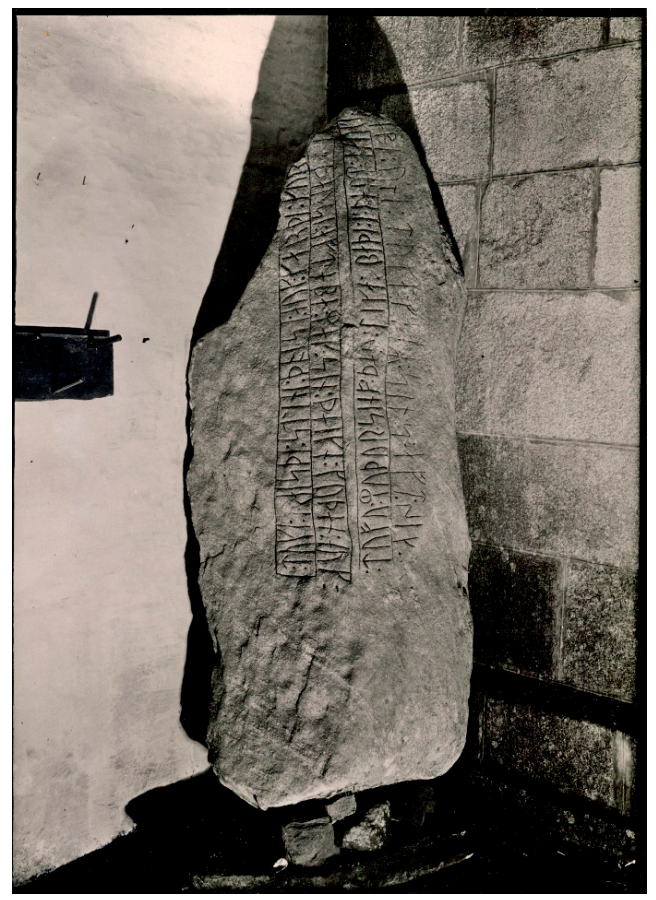

Fig. 1. DR 143 Gunderup 1. Foto: Erik Moltke (1931), Nationalmuseet, Danmark (CC BYSA).
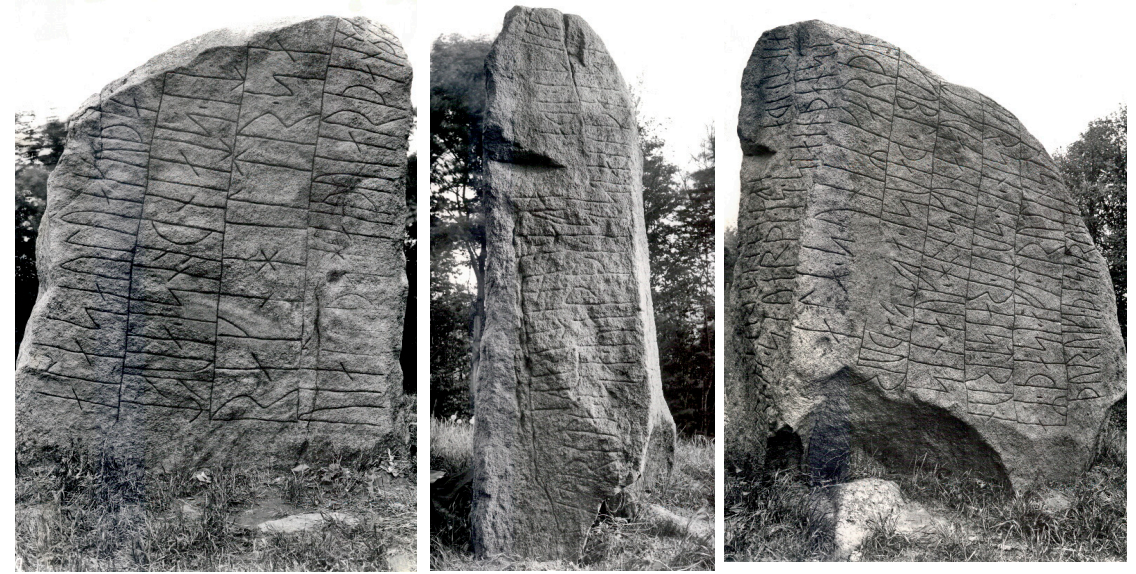

Fig. 2. DR 209 Glavendrup. vänster) parti A. mitten) parti C. höger) parti C och B. Foton: Erik Moltke (1930-1939), Nationalmuseet, Danmark (CC BY-SA). 


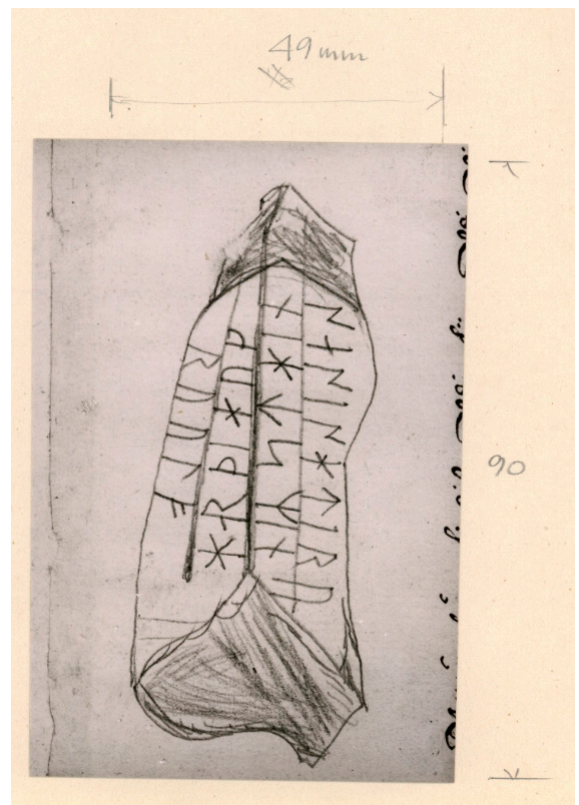

Fig. 3. DR 189 Avnslev. Teckning: Jon Skonvig (1627), Nationalmuseet, Danmark (Public Domain).

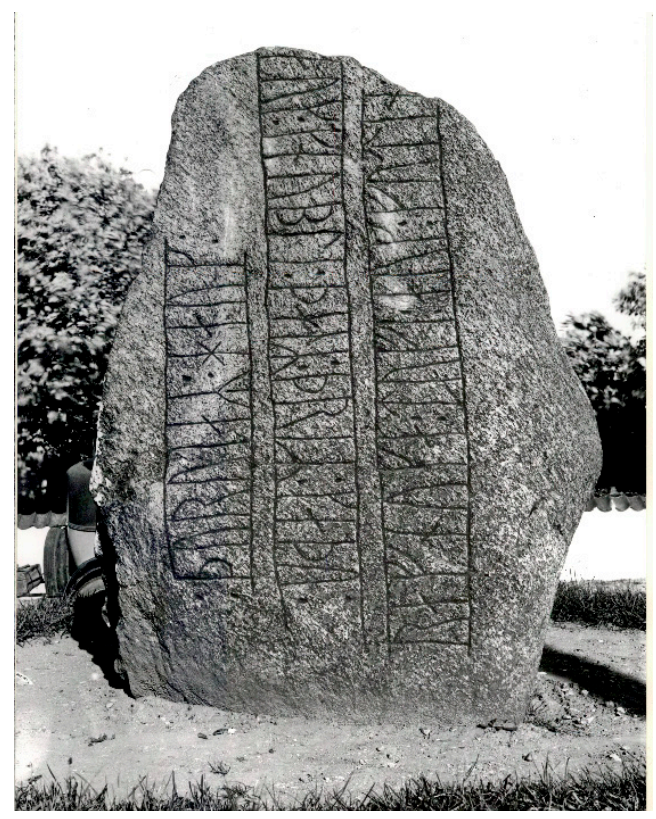

Fig. 4. DR 29 Bække 1. Foto: Erik Moltke (1932), Nationalmuseet, Danmark (CC BY-SA).

Futhark 9-10 (2018-2019) 


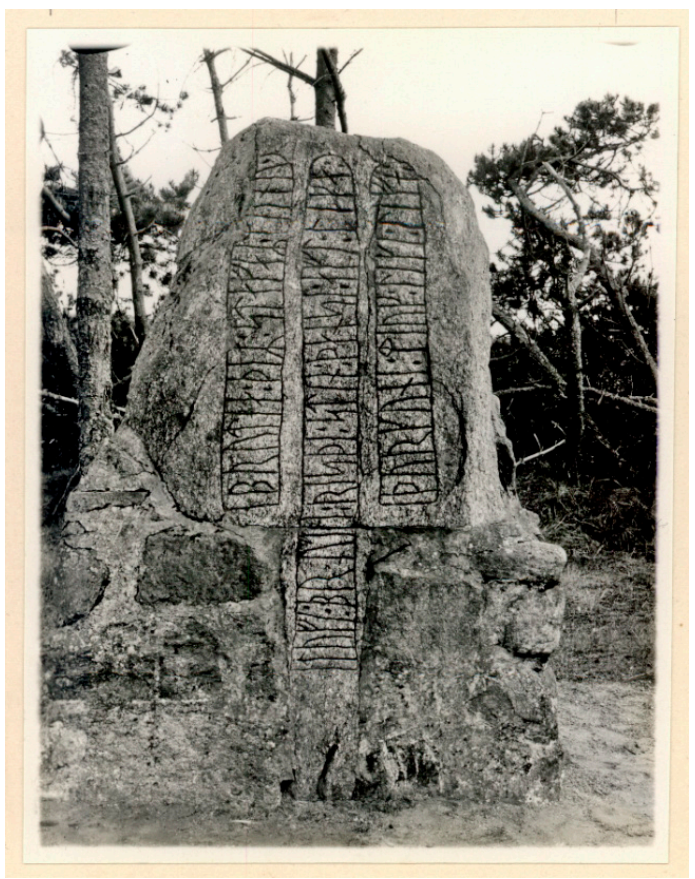

Fig. 5. DR 40 Randbøl. Foto: Erik Moltke (1930-1939), Nationalmuseet, Danmark (CC BYSA).

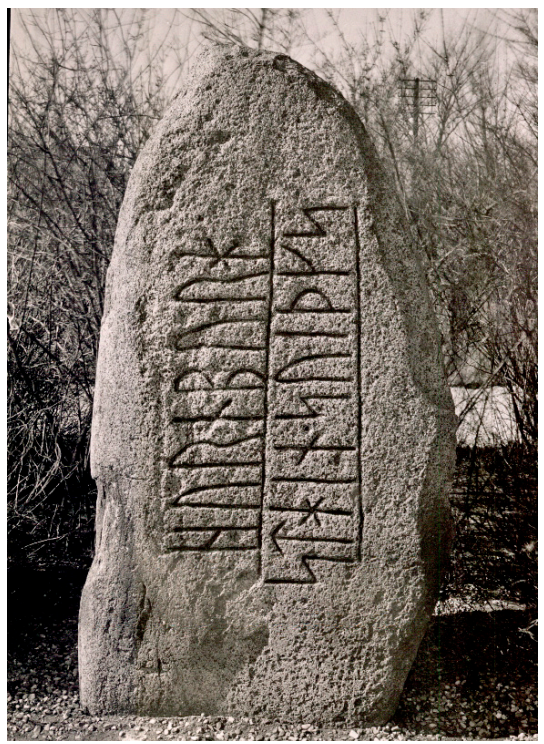

Fig. 6. DR 250 Høje Tåstrup. Foto: Erik Moltke (1930-1939), Nationalmuseet, Danmark (CC BY-SA). 


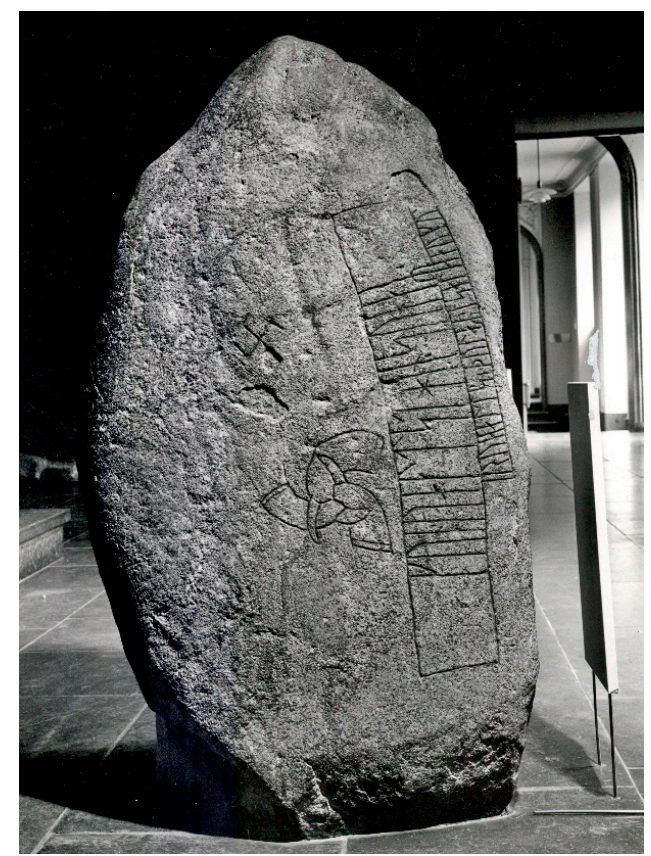

Fig. 7. DR 248 Snoldelev. Foto: Erik Moltke (1974), Nationalmuseet, Danmark (CC BY-SA).

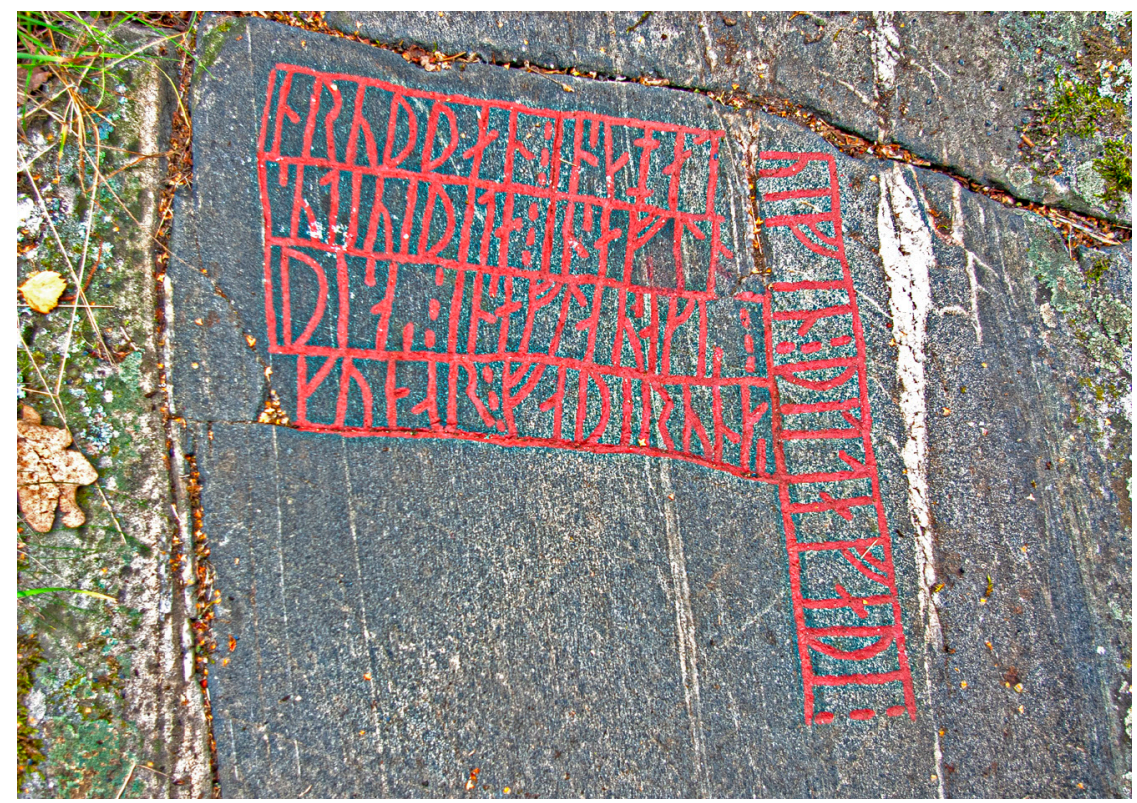

Fig. 8. Ög N288 Oklunda. Foto: Marco Bianchi (2006; CC BY).

Futhark 9-10 (2018-2019) 

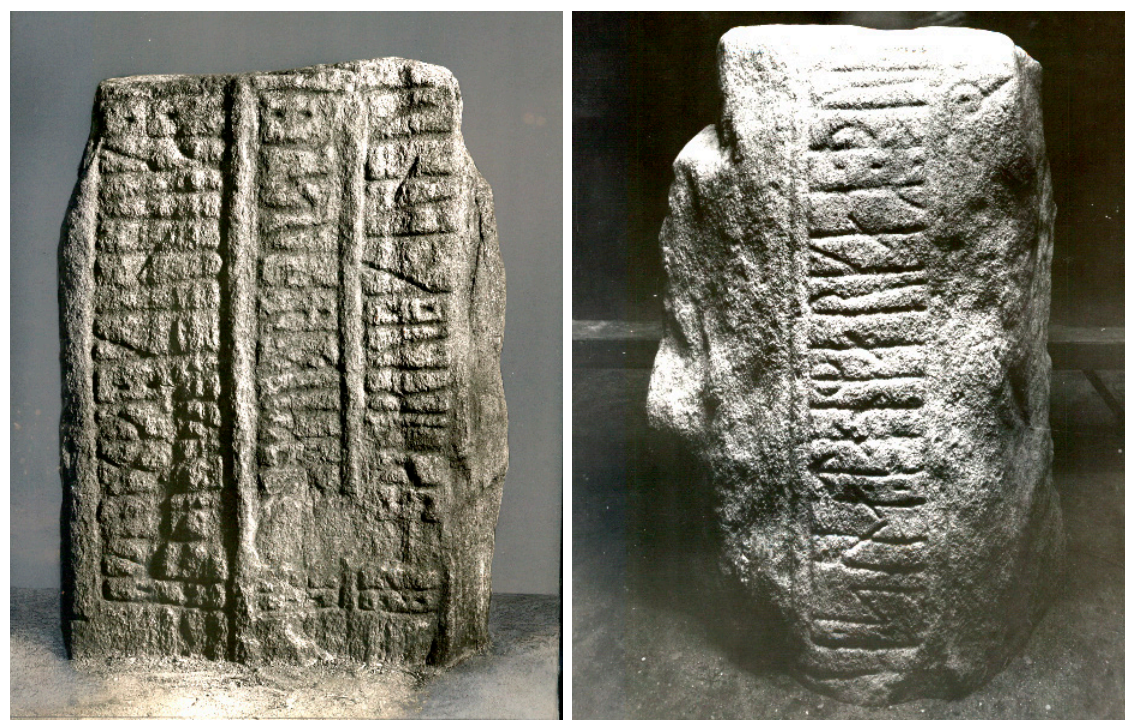

Fig. 9. DR 41 Jelling 1. vänster) parti A. höger) parti B. Foton: Erik Moltke (1929 respektive 1930-1939), Nationalmuseet, Danmark (CC BY-SA).

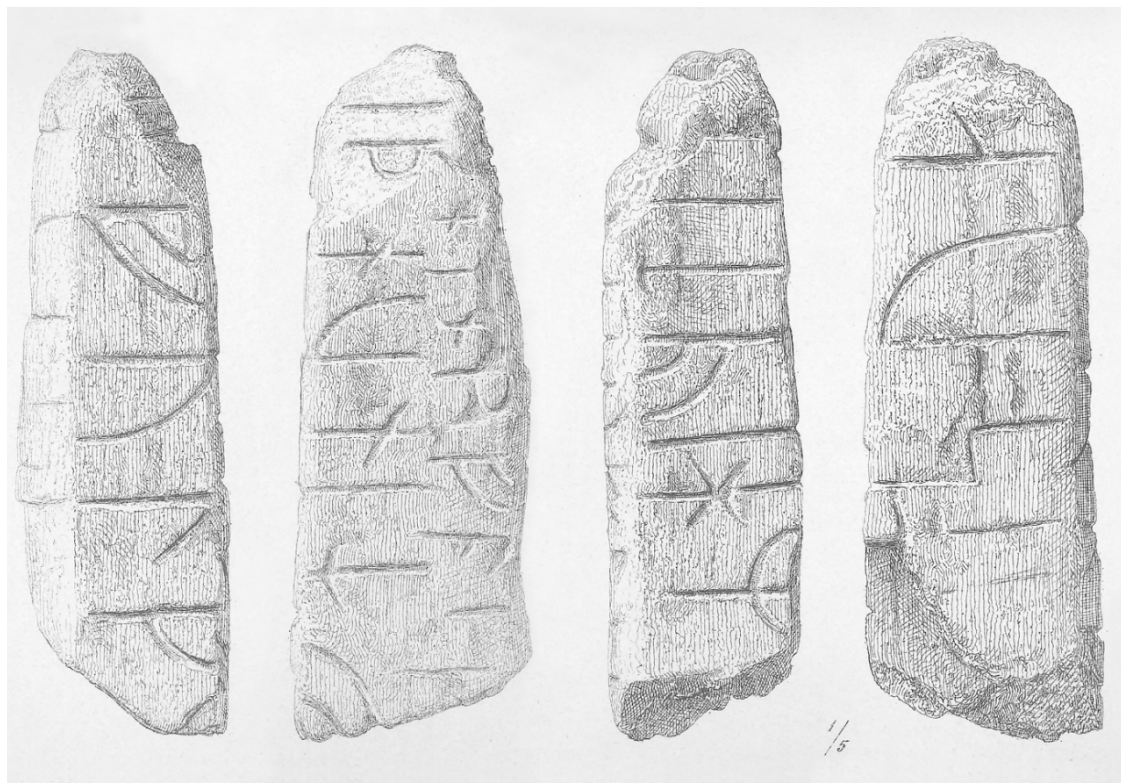

Fig. 10. Bo Boije4 Skee. Partierna visas från vänster mot höger i ordningen $A, B, C$ och $\mathrm{D}$, presenterade enligt principen sida för sida mot höger. Bilderna är riktade med Boijes (1884-1886, 274) antagna topp uppåt. Teckning hämtad från Boije (1884-1886); bearbetad av författaren. 


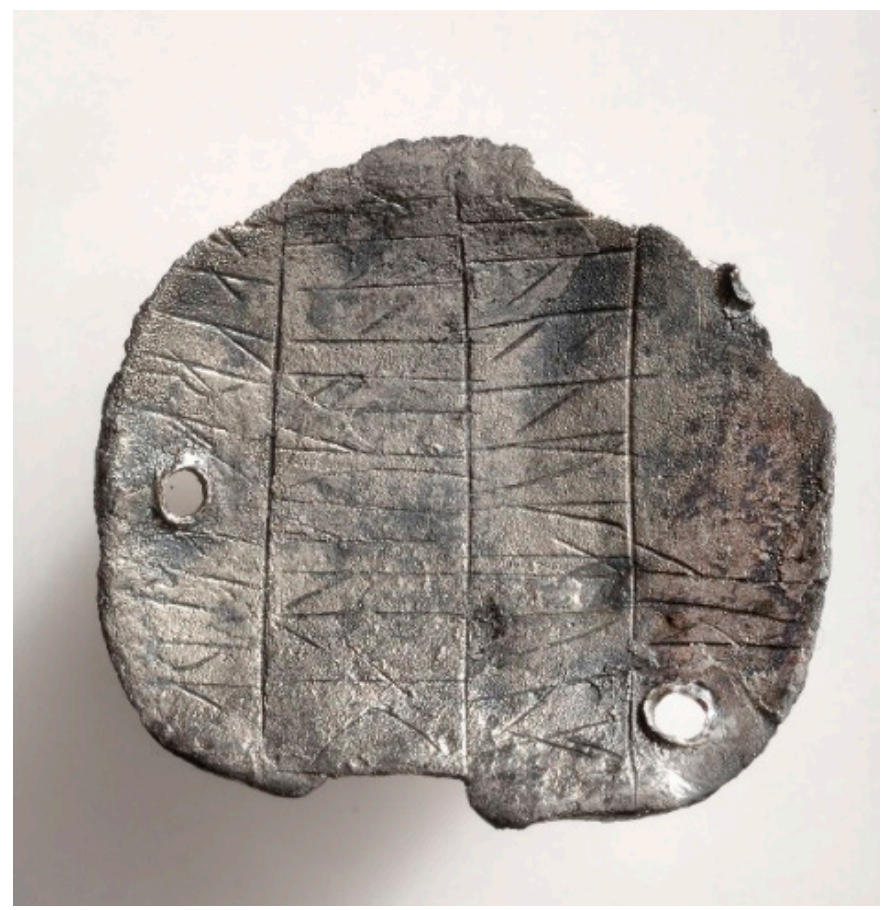

Fig. 11. ANF1937;163 Björkö. Raderna visas från vänster mot höger i ordningen 1-2-3-4. Foto: Gabriel Hildebrand (2013), Statens historiska museum, Stockholm (CC BY). 


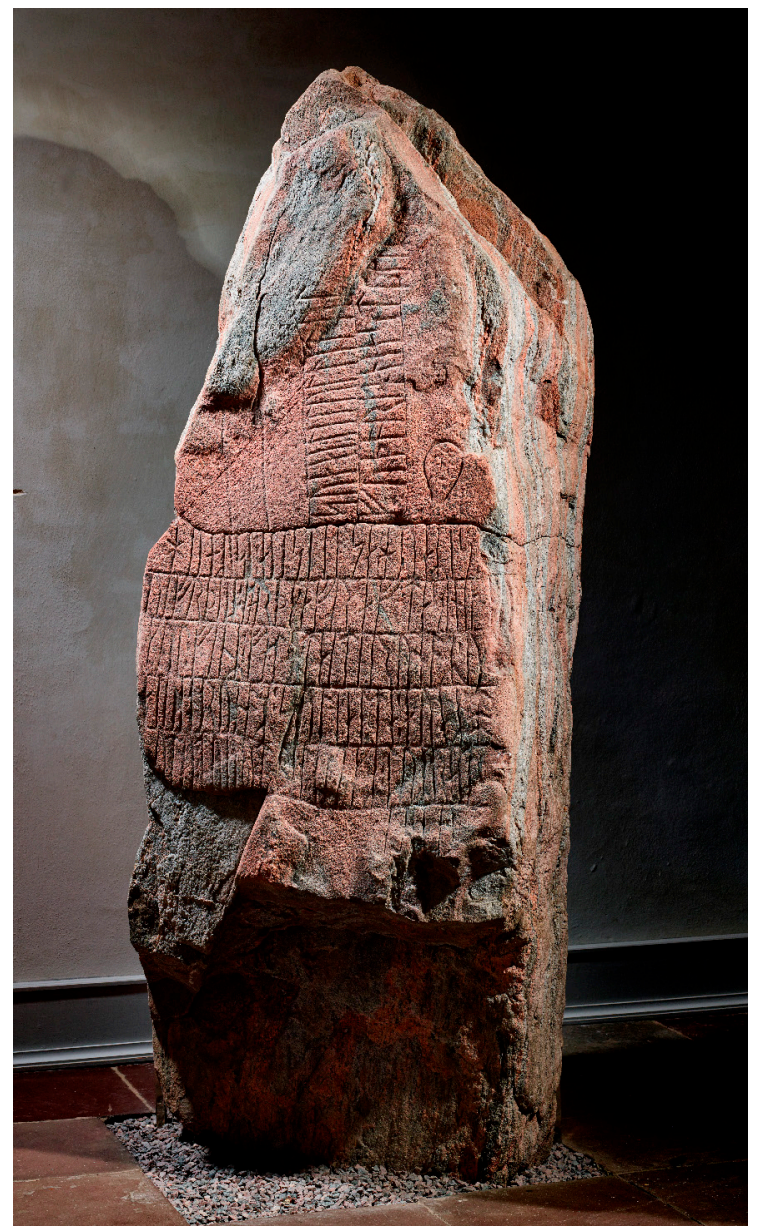

Fig. 12. DR NOR1988;5 Malt. Foto: Roberto Fortuna (2014), Nationalmuseet, Danmark (CC BY-SA). 


\section{Förkortningar och bibliografi}

ANF = Arkiv för nordisk filologi 1- (1883 ff.).

Andrén, Anders. 2000. "Re-reading Embodied Texts - an Interpretation of Runestones." Current Swedish Archaeology 8: 7-32.

Antonsen, Elmer H. 2002. Runes and Germanic Linguistics. Trends in Linguistics, Studies and Monographs, 140. Berlin.

AST1 = Arthur Nordén 1943. "Bidrag till svensk runforskning." I Antikvariska studier, 1: 143-224. Kungl. Vitterhets-, historie- och antikvitetsakademiens handlingar, 55. Stockholm.

ATA = Antikvarisk-topografiska arkivet, Riksantikvarieämbetet. Stockholm.

[DR] AUD[årtal] = Arkæologiske Udgravninger i Danmark (København, 1988 ff.).

Bianchi, Marco. 2008. "Runstenar och vikingatida skriftkultur i Kronobergs län.” I Runor i Kronobergs län, red. Per Stille och Martin Hansson, 20-31. Kronobergsboken 2008. Växjö.

— . 2010. Runor som resurs: Vikingatida skriftkultur i Uppland och Södermanland. Runrön, 20. Uppsala.

Birkmann, Thomas. 1995. Von Ågedal bis Malt. Ergänzungsbände zum Reallexikon der germanischen Altertumskunde, 12. Berlin.

— . 1994. "Zum Namen uifrpur auf dem Runenstein von Malt." I Proceedings of the Third International Symposium on Runes and Runic Inscriptions, Grindaheim, Norway, 8-12 August 1990, red. James E. Knirk, 203-215. Runrön, 9. Uppsala.

Björkvall, Anders. 2003. Svensk reklam och dess modelläsare. Acta Universitatis Stockholmiensis, Stockholm Studies in Scandinavian Philology, n.s., 31. Stockholm.

— . 2004. "Modelläsare i svensk tidskriftsreklam: Erbjudanden om olika typer av konsumerande identiteter." I Svenskans beskrivning, vol. 26: Förhandlingar vid Tjugosjätte sammankomsten för svenskans beskrivning, Uppsala den 25-26 oktober 2002, red. Björn Melander et al., 87-96. Uppsala.

— . 2009. Den visuella texten: Multimodal analys i praktiken. Ord och Stil, Språkvårdssamfundets skrifter, 40. Uppsala.

Blindheim, Charlotte. 1982. "Slemmedal-skatten: En liten orientering om et stort funn." Viking: Tidsskrift for norrøn arkeologi 45: 5-31.

[Öl] $\mathrm{BN}+\mathrm{nr}=$ inskrift publicerad i Bruce E. Nilsson, The Runic Inscriptions of Öland, Ph.D.-avhandling från University of Minnesota (Ann Arbor, Mich., 1973).

Bo = runristning från Bohuslän.

Boije, Sten. 1884. "Bohusläns runinskrifter.” Bidrag till kännedom om Göteborgs och Bohusläns fornminnen och historia 3 (1884-1886): 258-288.

[Bo] Boije4 = runristning med nummer 4 i Sten Boije 1884.

Braunmüller, Kurt. 1991. "Mutmaßungen zum Maltstein: Methodenkritische Anmerkungen zu runologischen Interpretationen." I Festskrift til Ottar Grønvik på 75-årsdagen den 21. oktober 1991, red. John Ole Askedal et al., 110-123. Oslo.

Futhark 9-10 (2018-2019) 
— . 1992. "Der Maltstein: Versuch einer Deutung." Frühmittelalterliche Studien 26: $149-164$.

Bugge, Sophus. 1891-1903. Norges Indskrifter med de ældre Runer. Vol. 1. Christiania.

Bäckvall, Maja. 2013. Skriva fel och läsa rätt? Eddiska dikter i Uppsalaeddan ur ett avsändar- och mottagarperspektiv. Nordiska texter och undersökningar, 31. Uppsala.

Danmarks Runeindskrifter. Av Lis Jacobsen och Erik Moltke. 3 vol.: Text; Atlas; Registre. København, 1941-1942.

Danske Runeindskrifter [databas]. Nordisk forskningsinstitut, Københavns universitet. http://runer.ku.dk/

$\mathrm{DE}=$ Inskrift från Tyskland

[DR] DK = löpnummer per region i Danske Runeindskrifter, http://runer.ku.dk/

$D R=$ Danmarks Runeindskrifter

$\mathrm{DR}+\mathrm{nr}=$ inskrift publicerad i Danmarks Runeindskrifter.

Duczko, Wladyslaw. 1985. Birka: Untersuchungen und Studien, vol. 5: The Filigree and Granulation Work of the Viking Period: An Analysis of the Material from Björkö. Stockholm.

Eco, Umberto. 1981. The Role of the Reader: Explorations in the Semiotics of Texts. London.

EM85 = Erik Moltke. Runes and Their Origin, Denmark and Elswhere. Copenhagen, 1985.

Fridell, Staffan, och Veturliði Óskarsson. 2011. "Till tolkningen av Oklundainskriften." Saga och Sed 2011: 137-150.

Friesen, Otto von. 1914. "Gursten: En runsten och ett gårdsnamn." Namn och bygd: Tidskrift för nordisk ortnamnsforskning 2: 1-17.

$\mathrm{Fv}=$ Fornvännen: Tidskrift för svensk antikvarisk forskning (utg. av Kungl. Vitterhets Historie och Antikvitets Akademien, 1906 ff.).

$\mathrm{G}+\mathrm{nr}=$ inskrift publicerad i Gotlands runinskrifter, d.v.s. SRI, 11-12. Nummer över G 222 återfinns i Helmer Gustavson och Thorgunn Snædal, manus till Gotlands runinskrifter, del 3. https:/www.raa.se/kulturarv/runor-och-runstenar/ digitala-sveriges-runinskrifter/gotlands-runinskrifter-3/

Grønvik, Ottar. 1981. Runene på Tunesteinen: Alfabet-Språkform-Budskap. Oslo.

—. 1991. ”Den nyfunne runesteinen fra Malt i Jylland - en religionshistorisk viktig innskrift fra omkring 900.” Det norske Videnskaps-Akademi, Arbok 1990: 187-207.

—. 1992. "Runesteinen fra Malt i Jylland." Arkiv för nordisk filologi 107: 1-34.

Gustavson, Helmer. 2003. "Rök." I Reallexikon der Germanischen Altertumskunde, grundad av Johannes Hoops, red. Heinrich Beck et al., 25: 62-72. 2. uppl. Berlin.

Gustavson, Helmer, och Klas-Göran Selinge. 1988. ”Jarlabanke och hundaret: Ett arkeologiskt/runologiskt bidrag till lösningen av ett historiskt tolkningsproblem.” Namn och bygd: Tidskrift för nordisk ortnamnsforskning 76: 19-85. 
Heltoft, Lars. 2017. "Maltstenens tekst: Hvordan dæmonen uddrives.” Danske Studier 2017: 27-100.

Holmberg, Per. 2016. ”Svaren på Rökstenens gåtor: En socialsemiotisk analys av meningsskapande och rumslighet." Futhark 6 (2015): 65-106.

Holmberg, Per, och Anna-Malin Karlsson. 2006. Grammatik med betydelse: En introduktion till funktionell grammatik. Ord och Stil, Språkvårdssamfundets skrifter, 37. Uppsala.

Holmberg, Per, Bo Gräslund, Olof Sundqvist och Henrik Williams. 2020. ”The Rök Runestone and the End of the World." Futhark 9-10 (2018-2019): 7-38.

$\mathrm{Hs}+\mathrm{nr}=$ runristning med nummer i Marit Åhlén, "Runinskrifter i Hälsingland", Bebyggelsehistorisk tidskrift 27 (1994): 33-50.

Imer, Lisbeth M. 2007. "Runer og runeindskrifter: Kronologi, konstekst og funktion i Skandinaviens jernalder og vikingetid." 2 vol.: ”Tekst”; "Katalog”. Otryckt Ph.d.-avhandling från Københavns universitet.

Jesch, Judith. 1998. "Still Standing in Ågersta: Textuality and Literacy in Late Viking-Age Rune Stone Inscriptions.” I Runeninschriften als Quellen interdisziplinärer Forschung: Abhandlungen des Vierten Internationalen Symposiums über Runen und Runeninschriften in Göttingen vom 4.-9. August 1995, red. Klaus Düwel, 462-475. Ergänzungsbände zum Reallexikon der Germanischen Altertumskunde, 15. Berlin.

Johnsen, Ingrid Sanness. 1968. Stuttruner i vikingtidens innskrifter. Oslo.

Karlsson, Anna-Malin. 2002. Skriftbruk i förändring: En semiotisk studie av den personliga hemsidan. Acta Universitatis Stockholmiensis, Stockholm Studies in Scandinavian Philology, n.s., 25. Stockholm.

$\mathrm{KJ}+\mathrm{nr}=$ inskrift publicerad i Krause 1966.

Kousgård Sørensen, John. 1989. ”Om personnavne på -vi/-væ og den førkristne præstestand: Med nogle overvejelser over en omstridt passage i Glavendrupstenens indskrift." Danske Studier 1989: 5-33.

Krause, Wolfgang, med bidrag av Herbert Jankuhn. 1966. Die Runeninschriften im älteren Futhark. 2 vol. Abhandlungen der Akademie der Wissenschaften in Göttingen, philologisch-historische Klasse, 3 ser., 65. Göttingen.

Kress, Gunther. 2005. "Gains and Losses: New Forms of Texts, Knowledge, and Learning." Computers and Composition 22: 5-22.

Kress, Gunther, och Theo van Leeuwen. 2006. Reading Images: The Grammar of Visual Design. 2 utg. London.

Källström, Magnus. 2007. Mästare och minnesmärken: Studier kring vikingatida runristare och skriftmiljöer $i$ Norden. Acta Universitatis Stockholmiensis, Stockholm Studies in Scandinavian Philology, n.s., 43. Stockholm.

— . 2013. "Vikingatida och medeltida skrifttraditioner: Några iakttagelser med utgångspunkt i det svenska runmaterialet." Futhark 4: 101-128.

Liestøl, Aslak. 1982. "Runene i Slemmedal-skatten." Viking: Tidsskrift for norrøn arkeologi 45: 44-48.

Leeuwen, Theo van. 2005. Introducing Social Semiotics. London. 
Loman, Bengt. 1965. "Rökrunorna som grafematiskt system.” Arkiv för nordisk filologi 80: 1-60.

Machin, David. 2007. Introduction to Multimodal Analysis. London.

Melnikova2001 = Elena A. Mel'nikova. 2001. Skandinavskie runičeskie nadpisi: Novye naxodki i interpretatsii: Teksty, perevod, kommentarij. Moskva.

Meyer, Jan. 1992. "Planning in Runic Inscriptions." I Blandade runstudier, 1: 3766. Runrön, 6. Uppsala.

MLUHM1983-84 = Lars Larsson och Evert Salberger. "A Rune-Inscribed Detail of a Comb from L:a Köpinge, Scania.” Meddelanden från Lunds universitets historiska museum 1983-1984 (1984): 128-137.

Moltke, Erik. 1981. ”Järsbergstenen, en mærkelig värmlandsk runesten.” Fornvännen 76: 81-90.

[Ög] N = Arthur Nordén. "Óstergötlands runinskrifter: Supplement till Erik Brates 'Ostergötlands runinskrifter'." Manuskript i ATA.

$\mathrm{N}+\mathrm{nr}=$ inskrift publicerad i Norges innskrifter med de yngre runer, av Magnus Olsen et al., 6 vol. hittills (Oslo, 1941 ff.).

$\mathrm{N} \mathrm{A}+\mathrm{nr}=$ arkivnummer i Runearkivet, Oslo.

NLT $=$ Norsk lingvistisk tidsskrift (Oslo, 1983 ff.).

NOR = Nytt om runer 1-19 (Oslo, 1986-2004 [publ. 2006]).

Nord, Andreas. 2008. Trädgårdsboken som text 1643-2005. Acta Universitatis Stockholmiensis, Stockholm Studies in Scandinavian Philology, n.s., 47. Stockholm.

Nordén, Arthur. 1937. "Magiska runinskrifter." Arkiv för nordisk filologi 53: 147-189.

—. 1940. "Litteratur och kritik: Tysk runforskning under de sista åren." Fornvännen 35: 318-332.

Nyström, Staffan. 1992. "Runes and Runestones from Birka." I Investigations in the Black Earth, vol. 1: Early Investigations and Future Plans, red. Björn Ambrosiani och Helen Clarke, 64-70. Birka Studies, 1. Stockholm.

Palm, Rune. 1992. Runor och regionalitet: Studier av variation i de nordiska minnesinskrifterna. Runrön, 7. Uppsala.

Pereswetoff-Morath, Sofia. 2019. Viking-Age Runic Plates: Readings and Interpretations. Runrön, 21. Uppsala.

Peterson, Lena. 1992. ”Hogastenen på Orust.” I Blandade runstudier, 1: 81-111. Runrön, 6. Uppsala.

—. 1994. Svenskt runordsregister. 2 rev. uppl. Runrön, 2. Uppsala.

Peterson1992 = Peterson 1992.

Petrulevich, Alexandra. 2016. Ortnamnsanpassning som process: En undersökning av vendiska ortnamn och ortnamnsvarianter i Knýtlinga saga. Namn och samhälle, 28. Uppsala.

$\mathrm{RU}=$ inskrift från Ryssland.

Ralph, Bo. 2007. "Gåtan som lösning: Ett bidrag till förståelsen av Rökstenens runinskrift." Maal og minne 2007: 133-157.

Salberger, Evert. 1980. Óstgötska runstudier. Scripta runica, 1. Göteborg.

Samnordisk runtextdatabas. Institutionen för nordiska språk, Uppsala universitet. http://www.nordiska.uu.se/forskn/samnord.htm 
Samplonius, Kees. 1992. "Zum Runenstein von Malt." Amsterdamer Beiträge zur älteren Germanistik 36: 65-91.

Sangfelt, Adrian. 2019. Syntaktiska strukturer $i$ tiden: OV- och bisatsledföljd $i$ svenskans historia. Studia philologiae Scandinavicae Upsaliensia, 20. Uppsala.

$\mathrm{Sm}+\mathrm{nr}=$ inskrift publicerad i Smålands runinskrifter, d.v.s. SRI, 4.

$S R I=$ Sveriges runinskrifter. Olika författare; publicerade av Kungl. Vitterhets Historie och Antikvitets Akademien. 14 vol. hittills. Stockholm, $1900 \mathrm{ff}$.

SRI, 1 = Ölands runinskrifter, av Sven Söderberg och Erik Brate (1900-06).

SRI, 2 = Östergötlands runinskrifter, av Erik Brate (1911-18).

SRI, 3 = Södermanlands runinskrifter, av Erik Brate och Elias Wessén (1924-36).

SRI, 4 = Smålands runinskrifter, av Ragnar Kinander (1935-61).

SRI, $5=$ Västergötlands runinskrifter, av Hugo Jungner och Elisabeth Svärdström (1940-70).

SRI, 6-9 = Upplands runinskrifter, av Elias Wessén och Sven B. F. Jansson (1940-58).

SRI, 11-12 = Gotlands runinskrifter, av Sven B. F. Jansson, Elias Wessén, och Elisabeth Svärdström (1962-78).

SRI, 14.2 = Värmlands runinskrifter, av Sven B. F. Jansson (1978).

Stephens, George. 1874-1879. "Runstenen från Skee.” Bidrag till kännedom om Göteborgs och Bohusläns fornminnen och historia 1: 166-174.

Stoklund, Marie. 1989. "Arbejdet ved runologisk-epigrafisk laboratorium, København." Nytt om runer 3 (1988): 4-7.

—. 1994. "Malt-stenen - en revurdering." I Proceedings of the Third International Symposium on Runes and Runic Inscriptions, Grindaheim, Norway, 8-12 August 1990, red. James E. Knirk, 179-202. Runrön, 9. Uppsala.

- 1996. "The Ribe Cranium Inscription and the Scandinavian Transition to the Younger Reduced Futhark." I Frisian Runes and the Neighbouring Traditions: Proceedings of the First International Symposium on Frisian Runes at the Fries Museum, Leeuwarden 26-29 Fanuary 1994, red. Tineke Looijenga och Arend Quak = Amsterdamer Beiträge zur älteren Germanistik 45: 199-209.

— . 2004. "The Runic Inscription on the Ribe Skull Fragment." I Ribe excavations 1970-76, red. Mogens Bencard et al., 5: 27-42. Højbjerg.

Svensson, Jan, och Anna-Malin Karlsson. 2012. ”Inledning: Text, textforskning och textteori." Språk och stil 22.1: 5-30.

Sö $+\mathrm{nr}=$ inskrift publicerad i Södermanlands runinskrifter, d.v.s. SRI, 3.

Thompson, Claiborne W. 1975. Studies in Upplandic Runography. Austin, Texas.

Thuesen, Karen. 1990. Maltstenen: En runologisk undersøgelse af den sydjyske Maltindskrift. UJDS-Studier, 7. København.

Tønnesson, Johan. 2003. "Model Readers and Other Textual Strategies in Norwegian Historian Professor Finn Olstad's Paper 'New Perspectives on the Rise and Fall of the Working Class' (2000)." I Academic Discourse: Multidisciplinary Approaches, red. Kjersti Fløttum och François Rastier, 158-180. Oslo. 
—. 2004. Tekst som partitur, eller: Historievitenskap som kommunikasjon: Nærlesning av fire historikertekster skrevet for ulike lesergrupper. Acta Humaniora. Oslo.

$\mathrm{U}+\mathrm{nr}=$ inskrift publicerad i Upplands runinskrifter, d.v.s. SRI, 6-9.

Wessén, Elias. 1958. Runstenen vid Röks kyrka. Kungl. Vitterhets Historie och Antikvitets Akademiens Handlingar, Filologisk-filosofiska serien, 5. Stockholm. —. 1965. Svensk språkhistoria, vol. 3: Grundlinjer till en historisk syntax. 2 uppl. Stockholm.

Viking2011 = James Knirk, "Hogganvik-innskriften: en hard runologisk nøtt." Viking: Tidsskrift for norrøn arkeologi 74 (2011): 25-39.

Wimmer, Ludvig F. A. 1895-1908. De danske runemindesmærker. 4 vol. København. $\mathrm{Vg}+\mathrm{nr}=$ inskrift publicerad i Västergötlands runinskrifter, d.v.s. SRI, 5.

$\mathrm{Vr}+\mathrm{nr}=$ inskrift publicerad i Värmlands runinskrifter, d.v.s. SRI, 14.2.

Åkerström, Hanna. 2012. "Sm 144 Gursten: En småländsk runsten från tidig vikingatid." Magisteruppsats, Institutionen för nordiska språk, Uppsala universitet.

— . 2013. ”Interpunktion i runstensinskrifter från tidig vikingatid.” Masteruppsats, Institutionen för nordiska språk, Uppsala universitet.

— . 2019. ”Det tidigvikingatida runmaterialet: En inventering." Futhark 8 (2017): 7-88.

—. Manus. "Stentoftens läsordning."

Øeby Nielsen, Gunhild. 2001. "Runestones as Communication - the Danish Material." Offa 58: 165-172.

Ög $+\mathrm{nr}=$ inskrift publicerad i Östergötlands runinskrifter, d.v.s. SRI, 2.

$\mathrm{O} \mathrm{l}+\mathrm{nr}=$ inskrift publicerad i Ölands runinskrifter, d.v.s. SRI, 1.

\section{English summary}

\section{Reading order in early Viking Age runic inscriptions}

In the study of runic material, interest has primarily been focused on linguistic interpretation. Here I attempt to broaden the perspective by highlighting visual communication, specifically visual cues as to the reading pathway through the lines of an inscription. The first aim of the study is to identify (potential) common principles for visual offers as to reading order in texts from the Scandinavian runic material of the early Viking Age. A model of analysis based on the material has been developed as a first step. I further wish to demonstrate how the relevant principles can be applied to develop new insights into reading order. The second aim of the study is thus to use the identified principles of reading order to propose the visually offered reading order of three early Viking Age runic texts.

The material under investigation consists of the early Viking Age Scandinavian runic inscriptions. The period extends from the beginning of the 700s until approximately 950. The material comprises 133 inscriptions in total and a description of delimitation criteria as well as a list of inscriptions can be found in Åkerström 2019. 
The material is divided into two groups: Group 1 consists of inscriptions whose reading order can be determined in whole or in part on linguistic grounds (62 in number) while Group 2 contains inscriptions where this is partially or fully impossible (84 in number). Fourteen inscriptions thus belong to both groups as only parts of the reading order can be determined on linguistic grounds (see further tables 2-6). Only Group 1 can be employed to achieve the first aim of the essay; if the visual principles indicative of a particular reading order are to be investigated, this must proceed from an order that has not been determined on visual grounds. I therefore use reading orders which have been established linguistically and investigate the associated visual cues. A review of the material permits the formulation of various criteria for interpreting reading order as being linguistically determined. These are primarily associated with syntactic and semantic relationships in the inscription. The visual principles of reading order established from Group 1 are then used in the analysis of three inscriptions from Group 2 (Bo Boije4 Skee, U ANF1937;163 Björkö and DR NOR1988;5 Malt), which fulfils the second aim of the essay.

The focus here has not been placed on the reading order of the actual sender or recipient since it is difficult to state anything with certainty about this. Taking my basis in a view of text formulated by Eco (1981, 7-11), I instead consider the reading order offered by the text itself (with text referring here to the carving, both its linguistic and its visual form, as well as the carved object).

The investigation of reading order requires the specification of components between which the order can be determined. I follow Karlsson $(2002,42)$ in using the term visual element for such components. A review of the compositions represented in the material under investigation allows three types of visual elements to be distinguished. These have been established on a visual and (to a certain degree) linguistic basic and comprise: (inscription's) line, (inscription's) section and (inscription's) composition. A line is a runic sequence which runs more or less continuously in approximately the same direction. The carved object generally consists of different sides which are separated by their placement at different angles: a section refers to the carving on one side. A composition refers to all the carving on an object. The visual elements thus consist only of the carving itself although the location of the carving on the surface is considered in the analysis. All the visual elements are investigated to determine the start of reading (i.e. the place where the reading begins in the line, section or composition), while the reading pathway (i.e. the path from this point) is considered between lines and between sections, but not between compositions.

The theoretical framework is based on social semiotics, with particular emphasis laid on the multimodality of text, i.e. the fact that additional resources beyond language can express meaning in a text, for example image and layout. The visual expressions which organise the text and which are referred to as semiotic resources are in focus here. These have the potential to express meaning which is not fixed but negotiated within a social community. The study focuses on semiotic resources which in early Viking Age writing culture can potentially 
express meanings connected with functions such as the start of reading and the reading pathway.

The interaction between semiotic resource, meaning and function is investigated on the basis of Kress and van Leeuwen's (2006) model of analysis for studying the grammar of visual design. This model is based on the linguistic description of systemic-functional grammar, a linguistic theory in social semiotics. More precisely, the part of the model which concerns the visual organisation of text is employed, which means that I assume that resources associated with reading order can express concepts such as salience, creation of associations or demarcation. These semantic systems can be connected with functions of reading order; resources that express salience represent the prominent element as more important and thus deserving of the most attention (Kress and van Leeuwen 2006, 201-06). I thus construe the connection with the start of reading and reading pathway as consisting of reading the most prominent element first, thereafter the less prominent and so on. Resources that express the creation of associations and demarcation require, according to Kress and van Leeuwen, that the elements in question are presented as if connected to each other or separated respectively. The connection with reading order consists of the reading pathway being promoted between those elements which have a visual connection and discouraged between those which are demarcated from each other.

I anticipate that the resources should result in a strongly or weakly marked offer of reading order. The categorisation is primarily employed to evaluate different possibilities of reading order in an analysis of the three inscriptions from Group 2. Two factors are accorded significance in the analysis: firstly, the clarity or lack thereof of the resource in the individual composition; secondly, the frequency or infrequency of use of the resource in Group 1. In simple terms, clear and frequently used resources result in a strongly marked offer of reading order, while unclear and infrequently used ones result in a weak one. No automatic connection should be made between this categorisation of the resources and their place in early Viking Age text culture.

Several visual resources connected with reading order have been identified in the analysis of Group 1 . Seven resources express salience which can be linked to the start of reading in a section (i.e. the initial line). All but one of these are found in several variants. Rune size means that the initial line may have either relatively larger or smaller runes (the former variant is more common). Length of line entails the initial line being relatively long or short (the former variant is more common). Height of line implies that the initial line is placed either a little higher up or a little further down than the other lines. Runic density describes how the introductory runes of the initial line are either more sparse or more crowded in comparison with other lines. Punctuation marks distinguish the initial line either via their presence or absence. Line demarcation entails the introductory lines of a section being marked along both sides while the concluding one is marked only along one side. An uncommon variant also occurs where the reverse applies. Finally, larger grouping of lines implies that when one group of lines within a section is placed vertically and 
another horizontally, the reading begins in the group with the greater surface area. All of the resources mentioned can in principle also be connected to the reading pathway; if one visual element is more prominent there is always a less prominent element which should thus be read subsequent to the former.

Three resources which express salience can be linked to the opening section of a multisectional composition. These include larger inscriptional section which entails that the initial section is greater in surface area, and again rune size which here means that where two sections are approximately the same size, the start of reading occurs in the section with larger runic shapes. Line demarcation can also indicate the start of reading in a composition; the introductory section has framing lines while the concluding one lacks these.

Three resources which express the creation of associations can be linked to the reading pathway. Closeness between lines is very common and simply consists of lines in visual proximity to each other often being read consecutively. Adjacent starting point of line means that the reading pathway is offered between lines with a boustrophedon direction of reading. Adjacent starting point of section means that when boustrophedon reading order not only occurs within the section but continues beyond it, then the reading order of the lines will be the same in both sections.

There are four resources which express demarcation. Distance between lines means that a visual distance between lines indicates these should not be read consecutively. Distance to starting point of line means that in arrangements where some lines are boustrophedon and others are not, and where the order in which the lines are read changes direction, then the lines where the direction of reading runs in the same direction (i.e. does not run boustrophedon) are not to be read consecutively. Different direction of line means that where groups of lines in a section are separated from each other whereby some are positioned horizontally and others vertically, each group of lines should be read to completion before the next is begun. Finally, distance to starting point of section means that where lines in two sections run boustrophedon but where the boustrophedon direction does not extend over the separate sections (i.e. the direction of reading in the lines which are edge to edge follows the same direction), these two lines should not be read consecutively.

Lastly, five resources do not seem to express any of the three semantic systems and have therefore been assumed to be directly connected to reading order by convention. These include reading direction within line which means that the start of reading occurs in a line whose direction of reading runs upwards from the bottom. Placement of line occurs in three variants: the start of reading occurs in the line furthest to the left, furthest to the right or in the middle in a vertical arrangement of lines. Line order concerns the reading pathway and means that the order in which the lines are read either runs to the right (if the start of reading is furthest to the left), to the left (if the start of reading is furthest to the right) or changes direction (if the start of reading is in a middle line). The variant with the start of reading to the left and the reading pathway running to the right is the most com- 
mon. Resources have similarly been established which describe the start of reading and the reading pathway for sections in multisectional compositions: placement of section means that the start of reading either occurs in the section to the right or to the left, and section order entails the reading pathway thereafter running to the right or left respectively. Here also, the variant where the order of reading proceeds from the section to the left towards that on the right is the most common.

Three inscriptions from Group 2 have been analysed in the light of the resources which have been established. These are Bo Boije4 Skee, U ANF1937;163 Björkö and DR NOR1988;5 Malt. The text on the Skee stone allows several different reading orders. The composition comprises four sections, A, B, C and $\mathrm{D}$, and section $\mathrm{B}$ consists of three lines, the $\mathbf{i}, \mathbf{f}$ and $\mathbf{t}$-lines (see fig. 10). The start of reading in section $B$ probably occurs in the $f$-line, which provides the most frequent variants of rune size and placement of line, as well as reading direction within line. The most strongly marked offer of reading pathway in section B is $\mathbf{f}-\mathbf{i}-\mathbf{t}$ (via adjacent starting point of line as well as the most frequent variant of line order). There is a strongly marked offer for the start of reading of the whole composition in the $\mathbf{f}$-line in section B (through larger section and reading direction within line) and in section $\mathrm{D}$, primarily through rune size and reading direction within line. Alternative reading pathways with the start of reading in sections $\mathrm{B}$ or $\mathrm{D}$, however, include the alternative $\mathrm{D}-\mathrm{A}-\mathrm{B}(\mathbf{f}-\mathbf{i}-\mathbf{t})-\mathrm{C}$ as the most strongly marked, but if the start of reading is considered to be in section $B$, then $B(\mathbf{f}-\mathbf{i}-\mathbf{t})$ $\mathrm{C}-\mathrm{D}-\mathrm{A}$ is a possible alternative (via the most frequent variant of section order).

The inscription U ANF1937;163 occurs on a silver pendant from Björkö. This comprises four lines of carving (A, B, C and D, see fig. 11), offering two alternative reading orders. The first A-B-C-D is marked a little more strongly (principally via length of line and adjacent starting point of line) than the second B-A-C-D (primarily via rune size).

On DR NOR1988;5 Malt there are six horizontal lines, H1-6, and two vertical ones, V1 and V2 (see fig. 12). There is an offer of reading these groups of lines individually (different direction of lines); the horizontal lines cover a much larger area than the vertical (larger grouping of lines). In the two vertical lines there is a slightly more strongly marked offer of start of reading in the line furthest to the right, V2, primarily via length of line. This does however entail that the less frequent variants of placement of line as well as line order are employed, i.e. from the line to the right and towards the left. In the horizontal lines there is an offer of reading order from top to bottom (H1-6), principally via the most frequent variant of placement of line and line order, but the start of reading in the uppermost line, $\mathrm{H} 1$, is also offered via length of line and possibly via height of line. An alternative but somewhat less strongly marked offer of reading order is H2-H1-H3-H4-H5-H6. A start of reading in $\mathrm{H} 2$ is offered by rune size and possibly through length of line. If the start of reading is to be found in $\mathrm{H} 2$, this evidences an infrequent variant of line order where the order in which the lines are read changes direction.

An analysis of the visual offers is only one step in the process of establishing the reading order of an inscription. Consideration must also be given to orders 
which make the linguistic content comprehensible. One future step would thus be to investigate linguistic offers of reading order. Highlighting three inscriptions where the linguistic content is of little or no help in establishing the reading order does however show what possibilities exist using only the visual resources. It is hoped that the result can be used in the consideration of linguistic interpretations. As well as being used as tools in the analysis of reading order, the established resources are interesting as they offer an insight into early Viking Age writing culture. They indicate certain clear norms for the formulation of text during the period in question, but also show that there was potential for individual variation. 